OECD REGIONAL DEVELOPMENT PAPERS

\title{
Regions and Globalisation
}

\section{An original approach to regional internationalisation and its application to the case of France}

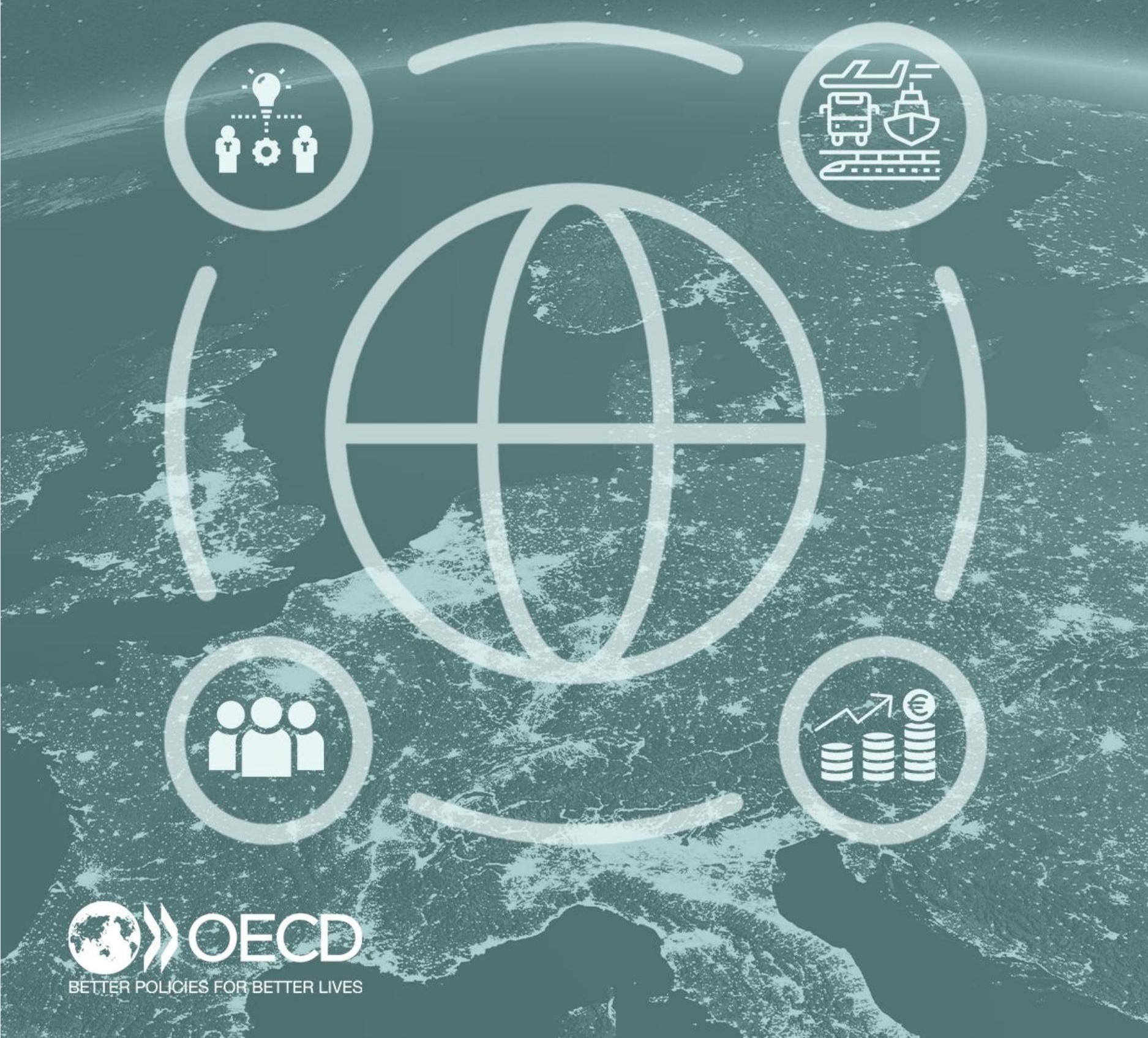


OECD Regional Development Papers

\title{
Regions and Globalisation
}

\section{An original approach to regional internationalisation and its application to the case of France}

\begin{abstract}
The COVID-19 crisis demonstrated that local authorities are on the front line when it comes to dealing with the various effects of globalisation. In France, as in OECD countries in general, responsibility for producing and implementing strategies that combine economic development, innovation and internationalisation falls to the regional level.

This summary document covers the main lessons learned from OECD policy analysis and statistical work carried out on French regions' internationalisation. It proposes an original methodology for assessing the position of regions in globalisation and applies this to France, comparing statistical observations with the internationalisation strategies adopted by French the regions. Also presented are multi-level governance measures in which the actors of regional internationalisation are involved.
\end{abstract}

JEL codes: $R 10, R 11$

Keywords: globalisation, internationalisation, territorial attractiveness, regional development, resilience, recovery, export strategies, multi-level governance, tourisme, infrastructure, knowledge networks, global value chains, migration

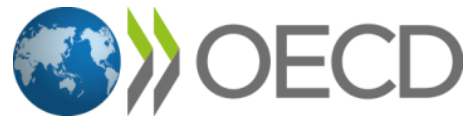




\section{ABOUT THE OECD}

The OECD is a multi-disciplinary inter-governmental organisation of 38 member countries which engages in its work an increasing number of non-members from all regions of the world. The Organisation's core mission today is to help governments work together towards a stronger, cleaner, fairer global economy. Through its network of 250 specialised committees and working groups, the OECD provides a setting where governments compare policy experiences, seek answers to common problems, identify good practice, and co-ordinate domestic and international policies. More information available: www.oecd.org.

\section{ABOUT OECD REGIONAL DEVELOPMENT PAPERS}

Papers from the Centre for Entrepreneurship, SMEs, Regions and Cities of the OECD cover a full range of topics including regional statistics and analysis, urban governance and economics, rural governance and economics, and multi-level governance. Depending on the programme of work, the papers can cover specific topics such as regional innovation and networks, sustainable development, the determinants of regional growth or fiscal consolidation at the subnational level. OECD Regional Development Papers are published on http://www.oecd.org/cfe/regional-policy.

This paper was authorised for publication by Lamia Kamal-Chaoui, Director, Centre for Entrepreneurship, SMEs, Regions and Cities, OECD.

This document, as well as any statistical data and map included herein, are without prejudice to the status of or sovereignty over any territory, to the delimitation of international frontiers and boundaries and to the name of any territory, city or area.

Cover photo credits: Gettylmages/NicoEINino

\section{(c) OECD 2021}

You can copy, download or print OECD content for your own use, and you can include excerpts from OECD publications, databases and multimedia products in your own documents, presentations, blogs, websites and teaching materials, provided that suitable acknowledgement of OECD as source and copyright owner is given. All requests for public or commercial use and translation rights should be submitted to rights@oecd.org. 


\section{Foreword}

The COVID-19 pandemic and policy responses - both to address immediate needs for health products, such as personal protective equipment (PPE) and to slow the spread through containment measures have reconfirmed the interwoven, and inter-dependent nature of our globalised economies and societies.

Recently, the impact of globalisation has been at the core of public debate. On one hand it has played at least partly - a role in widening territorial inequalities and, subsequently, reinforcing "geographies of discontent". On the other hand, evidence has demonstrated global value chains can be a source of resilience, by allowing firms to source their inputs more efficiently, to access knowledge and capital beyond the domestic economy and to expand their activities into new markets (OECD, 2020f). Until recently, little work has been done however on the impact of globalisation at the local level, despite the widely recognised view that this is where there are felt more strongly.

Adopting a territorial approach to understand globalisation is even more at stake as the crisis reveals wide territorial disparities in impact and response - in the short term with regard to health issues and in the longer term with regard to recovery from this unprecedented shock. At a time when employment, especially among young people, is becoming a priority objective, our way of life and resilience, both globally and locally, are being called into question. Voices are being raised, building on the awareness created by the crisis, requesting simpler, more inclusive development models that are better adapted to local realities and potential. These voices also underline the extent to which this "shift" must mobilise the various stakeholders: public and private (for-profit or non-profit), national (and even supranational in Europe), and, of course, territorial actors.

Regional authorities are at the heart of these negotiations. They are responsible for economic development and, therefore, (more or less exclusively) for dialogue with businesses in most OECD countries. They intervene directly to support investments (in transport, construction, communication, etc.) that influence the impact of economic activity on the environment and on cohesion. Regional authorities are often responsible for training, particularly vocational training, and adapting it to the needs of local labour markets. Consequently, they are directly concerned with inclusion and all aspects of economic success. While regions are an essential link in the short and long-term responses to the crisis, they do not act alone. Regional action, particularly in France, forms part of a multilevel governance system intended to harmonise powers and responsibilities, and public policies, from the local to the national (or even supranational) level.

This report presents the outcome of work begun in 2019 that aimed to equip regional and national actors with a shared tool for measuring regional internationalisation. In light of the various dimensions of territorial internationalisation, and given the absence of a comprehensive methodological tool in these areas, the OECD, in response to a request from France, launched an analytical study with the purpose of presenting an original approach to its Regional Development Policy Committee (RDPC). The OECD Secretariat benefitted from the support of the French government in this process, in particular from the General Commission for Territorial Equality (CGET) that has since become the National Agency for Territorial Cohesion (ANCT). This support made it possible to share thoughts on the elaboration of the analysis, to illustrate the indicators and to complement information by applying the methodology to the French regions. We supplemented this initial outline of the French regions' level of globalisation with an analysis of the 
regional internationalisation strategies contained in the Regional Plans for Economic Development, Innovation and Internationalisation (SRDEII). We extended the work to include the multilevel governance of internationalisation policies, which allowed us to consider the role of the national government in this partnership framework.

As a result of the crisis, this report has proved to be prescient and timely as currently there is not a single short- or long-term response plan that does not mention the relationship between globalisation and territories. By proposing a tool to measure regional globalisation through a variety of international "connections", this initial work is designed to help policy makers better understand the "international" characteristics of territories and better identify their needs and specific assets. To this end, this study uses a multidimensional and innovative statistical approach, as well as an analysis of the reference documents on the internationalisation strategies of the French regions in the form of the SRDEII. However, the latter may seem "outdated" given the extent to which the socio-economic environment in June 2020 differs from the conditions in 2016 when they were originally prepared. That said, by characterising the approaches to internationalisation that have been the focus of the regions' action since then, analysing the SRDEII can help to identify the structural aspects of the territorial approach to globalisation as well as those elements that remain priorities in French regional strategies. This can be updated at the second stage of this work. Lastly, this analysis made it possible to list the different practices for implementing internationalisation strategies. The crisis is forcing us to work together, and in this context the analysis reveals the tried-andtested coordination mechanisms on which it will be possible to base tomorrow's strategies.

This work has attracted the interest of the European Commission's Directorate-General for Structural Reform Support (DG REFORM), which, upon being approached by France, decided to provide financial support through its Structural Reform Support Programme (SRSP) to pursue the work, building on in-depth case studies of French regions carried out by the OECD for the French authorities.

The Policy Paper was submitted for approval by written procedure to the Regional Development Policy Committee on 17 June 2021 under the cote CFE/RDPC(2021)8. 


\section{Acknowledgements}

This report was produced by the OECD Centre for Entrepreneurship, SMEs, Regions and Cities (CFE) led by Lamia Kamal-Chaoui, and more specifically the Regional Development and Tourism Division headed by Alain Dupeyras.

Claire Charbit, Head of the Territorial Dialogues and Migration Unit, co-ordinated the France-OECD dialogue on regions and globalisation, supported by Junior Policy Analyst Martin Lestra. Statistician Eric Gonnard wrote the first chapter, which covers the statistical methodology. Martin Lestra wrote the second chapter, on policy analysis and governance. The other sections were written by Claire Charbit, with support from Martin Lestra and suggestions from Clément Malgouyres, economist at the Institut des Politiques Publiques (Paris School of Economics and the Centre for Research in Economics and Statistics). OECD consultant Chloé Gatignol contributed to the final version of this document. Our thanks go to the members of the Working Party on Territorial Indicators, whose discussions contributed to the statistical methodology.

This project was carried out by the OECD team, in close collaboration with teams from the National Agency for Territorial Cohesion (ANCT) of the Ministry for Territorial Cohesion and Relations with Local Government and the Régions de France association. Special thanks to: Luc Faraldi, ANCT International Policy Co-ordinator, French delegate to the Regional Development Policy Committee (RDPC) and Committee Bureau member, who greatly contributed to the initial conception and the implementation of this project through his unfailing commitment and advice; Jamila Jaaïdane, ANCT Co-ordinator of Economic Development Policies, whose expertise provided this project with useful documents, advice and contacts; Benoît de Lapasse, Head of Territorial Observation at the ANCT Territorial Analysis and Diagnostics Unit, for his suggestions and contribution to data collection; Jean-Christophe Baudouin, Interministerial Delegate for the Development of Ports and Logistics in the Méditerranée-Rhône-Saône region, for his availability and his insights on logistical and port issues; Marc Laget, Project Manager of the ANCT Nouveaux Lieux, Nouveaux Liens [New Places, New Links] programme, for his contributions regarding information and communication technology infrastructure; and Philippe Cichowlaz, Head of the European Cohesion Policy Department, for his valuable suggestions. We also warmly thank Jeremy PierreNadal, Director of Studies and Director of the Observatory of Regional Policies, and Mickaël Vaillant, Economic, Higher Education, Research and Digital Advisor, from the Régions de France association, for their interest in this project and their sound advice.

Finally, this work benefited from contributions from the Ministry for Europe and Foreign Affairs; the Ministry of the Economy, Finance and Recovery; Business France; Atout France (the France Tourism Development Agency); the Caisse des Dépôts Group; and Expertise France. We thank all of the managers interviewed for their interest in the project and their willingness to contribute their experience. 


\section{Table of contents}

Foreword 3

Acknowledgements $\quad 5$

List of acronyms $\quad 8$

Executive summary 9

$\begin{array}{ll}\text { Introduction } & 13\end{array}$

1 Methodology and internationalisation indicators $\quad 17$

1.1. A proposed framework for analysing the internationalisation of regions 18

1.1.1. Infrastructure connections 18

$\begin{array}{ll}\text { 1.1.2. Human connections } & 19\end{array}$

1.1.3. Knowledge connections 19

1.1.4. Business connections $\quad 19$

1.2. Proposed methodology for measuring regional internationalisation 20

$\begin{array}{ll}\text { 1.2.1. Internationalisation indicators } & 20\end{array}$

$\begin{array}{ll}\text { 1.2.2. Identifying baseline indicators } & 21\end{array}$

1.3. Position of the French regions according to the internationalisation indicators 26

1.4. Discussion of the indicators used and information to be added in the future 33

2 Exploring regional internationalisation policies and governance 34

2.1. The SRDEII: The first expression of the regions' jurisdiction over internationalisation 35

2.1.1. OECD methodology for SRDEII analysis 36

2.1.2. The internationalisation strategies of the French regions 38

2.2. Multilevel governance of regional internationalisation policies 53

2.2.1. SRDEII: The regions' proposals on multilevel governance of territorial
internationalisation

2.2.2. Other partners in regional internationalisation 56

2.2.3. Current State-region co-ordination on regional internationalisation: Public policy
examples

$\begin{array}{ll}\text { 2.2.4. Other national strategies for territorial internationalisation } & 67\end{array}$

Conclusion: Towards a more integrated and coherent vision of regional internationalisation

$\begin{array}{ll}\text { References } & 73\end{array}$ 


\section{Tables}

Table 1.1. Internationalisation indicators $\quad 20$

Table 1.2. Baseline indicators used in Figure 1.6: Profiles of the French regions 29

Table 2.1. Taxonomy of regional internationalisation policies and their governance 38

\section{Figures}

Figure 1.1. Example of the choice of baseline indicators for the French regions 22

Figure 1.2. French seaport activity by partner zone, 2018

Figure 1.3. French seaport and river port activity, $2018 \quad 24$

Figure 1.4. Regional air passenger traffic by destination, 2017-19 average 25

Figure 1.5. Convergence of regions in terms of labour productivity, 2000-16

Figure 1.6. Profiles of the French regions 30

Figure 2.1. Distribution of regional spending according to the classification of the functions of government (COFOG) (2016)

Figure 2.2. Positioning of the French regions according to the internationalisation indicators: infrastructure connections

Figure 2.3. Position of the French regions based on the internationalisation indicators: human connections

Figure 2.4. Position of the French regions based on the internationalisation indicators: knowledge connections 44

Figure 2.5. Position of the French regions based on the internationalisation indicators: business connections 47

Figure 2.6. Disparities in well-being between the French regions relative to OECD regions 51

Figure 2.7. Regional expenditure as a percentage of GDP and of total public expenditure (2016) 58

Figure 2.8. Institutional involvement in territorial policies to support exports (including Team France Export) 61

Figure 2.9. Institutions involved in regional attractiveness policies (including Team France Invest) 65

\section{Boxes}

Box 1.1. Port activity, a key element of regional development 23

Box 1.2. Regional air traffic $\quad 25$

$\begin{array}{lr}\text { Box 1.3. Definitions } & 26\end{array}$

$\begin{array}{ll}\text { Box 2.1. Regional well-being } & 51\end{array}$

Box 2.2. SRDEII: Territorial marketing and internationalisation strategies $\quad 54$

Box 2.3. Regional participation in international agendas 56

Box 2.4. The role of the National Agency for Territorial Cohesion in regional internationalisation 58

Box 2.5. Team France Export in the context of the COVID-19 crisis 62

Box 2.6. The organisation and territorial dimension of attractiveness in OECD countries 63

Box 2.7. The Committee for the Orientation and Monitoring of Foreign Projects, the central body of the Team France Invest scheme

Box 2.8. The regions' attractiveness policies and their co-ordination with the national government in the context of the crisis

Box 2.9. Strengthening multi-level governance: The case of port infrastructure along the Mediterranean-

Rhône-Saône axis 


\section{List of acronyms}

\begin{tabular}{l|l}
\hline ANCT & National Agency for Territorial Cohesion (France) \\
\hline- & Regional development agency \\
\hline- & Auvergne-Rhône-Alpes region \\
\hline CGCT & Regional chamber of commerce and industry \\
\hline- & General Local Authorities Code \\
\hline CRESS & International Standard Industrial Classification of All Economic Activities \\
\hline- & Regional Chamber of Social and Solidarity Economy \\
\hline DIRECCTE & Territorial Conference of Public Action \\
\hline EPCI & Regional Directorates for Business, Competition, Consumption, Labour and Employment \\
\hline- & Public Establishment for Intercommunal Cooperation \\
\hline ETI & Warehouse or logistics platform \\
\hline ERDF & Intermediate-sized enterprise \\
\hline- & European Regional Development Fund \\
\hline NUTS & Major seaport \\
\hline SMES & Nomenclature of territorial units for statistics (Eurostat) \\
\hline- & Small and medium-sized enterprises \\
\hline SUd region & Regional Plan for Business Internationalisation \\
\hline- & Provence-Alpes-Côte d'Azur region \\
\hline SDTAN & Regional Coherence Strategy for Digital Development \\
\hline- & Digital Territorial Development Master Plan \\
\hline SRADDET & Regional Scheme for Higher Education, Research and Innovation \\
\hline SRDEII & Regional Plan for Spatial Planning, Sustainable Development and Equality \\
\hline- & Regional Plan for Economic Development, Innovation and Internationalisation \\
\hline TL & Regional Scheme for the Development of Leisure and Tourism \\
\hline VSE & Territorial level (OECD) \\
\hline VIE & Very small enterprises \\
\hline & International volunteering in business \\
\hline & \\
\hline
\end{tabular}




\section{Executive summary}

Although there has been considerable attention on the impact of globalisation on our economies and societies, until recently, there had been much less on its impacts at the local level, despite the widely recognised view that this is where they are felt most keenly, driving, at least in part, regional inequalities and, in turn, geographies of discontent.

This, in large part, reflects its complexity. Understanding globalisation, its pros as well as its cons, requiries consideration of a number of factors. Whilst some of these will reflect the national level, for example tradeagreements, competition policy, exchange rates, many have a much more local dimension that is difficult to reflect in national measures. While, geography and culture for example are widely recognised as being important determinants of trade at the national level, they are arguably even more important at the subnational; level. Remote regions in a country, for example, will not be able to benefit from geography (or rather proximity to foreign markets and global value chains) in the same way as better connected regions. Indeed, remoteness creates challenges even if good quality transportation and communication networks exist, which is not always the case. Culture too can vary within countries, especially in regions with large migrant communities.

As a first step towards bridging the gap between the national and sub-national perspectives, this paper proposes a summary evaluation tool for the internationalisation of regions that considers four key determinants or "connections" linking territories to globalisation.

- Business connections: To capture international flows of goods, services and capital through companies.

- Knowledge connections: To capture international relations developed by public and private research centers and universities.

- Human connections: To reflect a wide range of channels of people-driven connection, such as tourism, short and long-term migration, seasonal employment, that can drive internationalisation.

- Infrastructure connections: To reflect the physical factors that enable both goods and services trade.

Applying the tool to France, this report, which was launched before the COVID-19 pandemic, comes at an ideal moment. In many countries and regions, the increased emphasis on resilience and greater appreciation of risks (for example ruptures) in supply-chains both by governments and the private sector has led to some rethinking on global value chains; in particular with respect to potential reshoring of activities in strategic sectors, such as pharmaceuticals and PPE equipment, notwithstanding the evidence that showed that GVCs could also be a source of resilience (OECD, 2020). This presents both threats and opportunities for firms and regions.

That rethinking is not altogether new. Even before COVID-19 there was already a greater appreciation of the need to ensure that globalisation worked for all. The crisis has, to some extent, heightened the discussion, through its acceleration of related megatrends such as the green transition, and an emphasis on building back better, with inclusiveness and resilience very much at the core. In the same vein, the crisis has shown that, in the new global environment, a successfully balanced development, the 
implementation of sustainable and lasting decisions, and a resilience that "leaves no one behind", must benefit from the widest possible involvement and therefore from the mobilisation of the specific social capital of each territory. These considerations underscore the crucial nature of governance and proper linkages between the various levels of administrative and political responsibility.

The work presented here considers these issues and also provides an inventory of the strategic projects developed by the French regions with regard to their internationalisation policies. To this end, it is based on the analysis of their Regional Strategies for Economic Development, Innovation and Internationalisation (SRDEII). Although they were devised in 2016-17 for the following five years, at a time when the extent of the challenges posed by the pandemic and its repercussions were still unknown, these strategies can be used to validate the proposed analytical framework as well as to underline the importance of their effective implementation of proper coordination between projects, and between the public and private actors behind them.

Chapter 1 presents the scope of analysis and the indicators used for each family of international connections: infrastructure connections; human connections; knowledge connections; business connections.

The list of internationalisation indicators is comprised of available data at the level of regions in France, Europe and OECD countries. The report recommends that going forward, data should be reinforced and compiled, in areas such as :

- The diversity of foreign trade partners of businesses in the region;

- The value added by local businesses on regional imports and included in their export

- The international activity of innovation hubs;

- The presence of cultural goods and services (museums, heritage, festivals).

Some of the available indicators, called "reference indicators", have been chosen using selection criteria to illustrate the international profiles of the French regions. In particular, they provide an insight into the strength of the close geographic ties between the French border regions and their foreign neighbors, and the diversity of the positioning of the French overseas regions in globalisation.

Chapter 2 compares the statistical observations to the Regions' strategies encapsulated in their SRDEII. From this study and the proposed additional items on some national strategies for the internationalisation of territories (in particular exports, attractiveness of investments and infrastructures) it appears that:

(i). Regions want to be involved in the various areas of internationalisation, without however necessarily adopting a holistic vision of internationalisation;

(ii). Regions are not acting in isolation to promote the internationalisation of their territories.

More specifically:

- Regions are primarily interested in measures to support business exports and the appeal of territories to investors. They are also developing policies in favour of tourism and international cooperation in research and innovation, and are actively supporting the international connectivity of infrastructures. The multitude of strategic documents drawn up by Regions seems to be an obstacle however to the emergence of a greater integration of the different facets of internationalisation in an overall regional strategy.

- In most cases, Regions have a "multi-objective" vision of internationalisation, in particular in terms of connecting training, attracting talented profiles, the competitiveness of local businesses at the international level, and attracting foreign investors. That said, they do not offer much in terms of solutions for attracting foreign talent to meet immediate and more medium-term needs in various sectors of their economies, and little is done to integrate the dimensions of well-being into their attractiveness strategies. 
- The SRDEII propose numerous institutional innovations for supporting the internationalisation of territories - interregional, cross border, European cooperation - shaped by the EU Research \& Innovation Framework and EU Cohesion Policies.

- Regions and their partners, notably the State and local authorities, are working to promote the internationalisation of territories, especially within the framework of ongoing reforms which reflect an integrated vision of economic development (e.g. the Plan France Haut Débit broadband programme, and the Team France Export and Team France Invest networks).

The pandemic has disrupted both the regional and national agendas, as illustrated in the discussions on the CPER (State-Region contracts) ${ }^{1}$ and the reorientation of European programming (Régions de France, 2020; European Commission, 2020). ${ }^{2}$ Indeed, the health crisis and environmental issues are not only raising questions about the ways in which the regions are involved in global value chains, but more fundamentally about the very dynamics of globalisation.

In this particular context, Regions are taking the lead alongside the State within the framework of the StateRegions recovery agreements and the State-Regions economic council, ${ }^{3}$ in responding to the crisis, particularly in terms of internationalisation. The Accord de méthode Etat-Régions (State-Regions method agreement - 30 July 2020) and the Accord de partenariat Etat-Régions (State-Regions partnership agreement - 28 September 2020) put forward priorities (ecological transition, economic sovereignty, reduced territorial inequalities, etc.) and internationalisation schemes (strengthening of the Team France Export and Invest programmes; simplification of innovation assistance, support for quality upgrading of tourist facilities, etc.) to support recovery in, and from, the territories.

In the short term, the regions have moved to meet demand for health equipment and to support the most affected populations and businesses in order to limit the impact on employment. In the medium and long term, they have expressed their desire to act on the supply side of global value chains by reshoring certain types of production deemed essential, notably through possible reshoring "pacts" for businesses. ${ }^{4}$ Moreover, the recovery plans announced by French Regions include strong measures for very "internationalised" business sectors such as aviation, digital and agriculture. Above all, Regions have proposed, within the framework of an industrial and environmental "New deal" (Régions de France, 2020) a short and long-term adaptation of internationalisation in coordination with the government:

- On the one hand, Regions want to take practical measures conducive to furthering internationalisation through "recovery contracts" for projects that have been curtailed or mothballed due to lack of resources in the areas of mobility infrastructures, science and technology projects, roll out of very high-speed broadband, etc.); or by reviving tourist activities;

- On the other hand, Regions want to implement a "new industrial policy" to foster resilience and the security of the production system.

These new challenges will inform the preparation of the next generation of strategic plans.

The COVID-19 pandemic is a reminder that internationalisation is not an end in itself. The use of conclusive evidence and the overview of internationalisation policies in this report can be used to underpin the new development models outlined by Regions in their recovery plans. Elsewhere, the new conditions of StateRegion cooperation must ensure that strategies for the internationalisation of territories do not lead to a

\footnotetext{
${ }^{1}$ Regions have proposed that recovery projects in response to the COVID-19 pandemic should rapidly be the subject of contractual agreements between the State and the regions and replace the current State-Region Contracts by incorporating complementary aspects. In this context, it has been agreed that the recovery plans for 2021-2022 could be a part of the next generation of StateRegion contracts for 2021-2027.

2 In addition to approving a multiannual financial framework for 2021-2027, the European Union announced a series of ambitious recovery programmes totalling 750 billion euros (programme Next Generation EU, initiatives Recovery and Resilience facility, Recovery Assistance for Cohesion and the Territories of Europe - REACT-EU), along with the strengthening of programmes supporting European regions (rural development programmes, Just Transition Mechanism, etc.) (European Commission, 2020b).

${ }^{3}$ This Council met for the first time on 18 December 2019.

${ }^{4}$ For example, the lle-de-France, Grand-Est and Occitanie regions have launched reshoring "packs" or "pacts"
} 
zero-sum game, with some gaining what others lose, and that openness and resilience are attained together to support the inclusive and sustainable development of French regions.

This report presents the outcomes of work begun in 2019 and which aimed to equip regional and national actors with a shared tool for measuring the internationalisation of regions. In light of the various dimensions of the internationalisation of territories, and given the absence of a comprehensive methodological tool in these areas, the OECD, in response to a request from France, launched an analytical study with the purpose of presenting an original approach to its Regional Development Policy Committee (RDPC). The OECD Secretariat benefitted from the support of the French government in this process, in particular from the General Commission for Territorial Equality (CGET) that has since become the National Agency for Territorial Cohesion (ANCT). This support made it possible to share thoughts on the elaboration of the analysis, to illustrate the indicators and to complete information by applying the methodology to the French regions.

As a result of the crisis, this report has proved to be prescient and timely as currently there is not a single short- or long-term response plan that does not mention the relationship between globalisation and territories. By proposing a tool to measure the position of the regions in globalisation through a variety of international "connections", this initial work is designed to help policymakers better understand the "international" characteristics of territories and better identify their needs and specific assets. To this end, this study uses a multidimensional and innovative statistical approach, as well as an analysis of the reference documents on the internationalisation strategies of the French regions in the form of the SRDEII.

The latter may seem "outdated" given the extent to which the socio-economic environment in June 2020 differs from the conditions in 2016 when they were originally prepared. That said, by characterising the approaches to internationalisation that have been the focus of the regions' actions since then, analysing the SRDEII can help to identify the structural aspects of the territorial approach to globalisation as well as what remains a priority in French regional strategies, (which will updated in a second stage of this work). Lastly, this analysis has made it possible to list the differentiated practices for implementing internationalisation strategies. The crisis is forcing us to work together, and in this context the analysis reveals the tried-and-tested coordination mechanisms on which it will be possible to base tomorrow's strategies.

This work has attracted the interest of the European Commission's Directorate-General for Structural Reform Support (DG REFORM), which, upon being approached by France, decided to provide financial support through its the Structural Reform Support Programme (SRSP) to pursue the work, building on indepth case studies of French Regions carried out by the OECD for the French authorities. 


\section{Introduction}

OECD countries face a wide range of territorial imbalances and are working to change these for the better. These imbalances are evident in disparities among the different regions of each country, between cities and different types of rural areas, and between metropolitan areas and their "hinterland". These territorial disparities can also affect different kinds of neighbourhoods within cities. This situation has, generallyspeaking, worsened since the 2008 crisis and is a source of inequality and significant tensions, which are reflected in a global geography of discontent. In France, the "yellow vest" crisis is the most notable manifestation of this phenomenon.

These disparities have a variety of causes and are partly rooted in the unique histories, geographies and economic development of the countries concerned. Whether economies are emerging or built on an ancient ecosystem of companies, infrastructure, vocational qualifications, generations of researchers and experts, and experience attracting and mobilising foreign talent, they all share a contemporary existence set against the backdrop of a globalisation that accelerated considerably at the turn of the millennium. This globalisation has multiplied and intensified flows of funds (incoming and outgoing), goods (raw materials, manufactured goods, waste and energy), people (both tourists and migrants), and information (innovation, expertise and artistic works). The continuous evolution of these flows and the courses they follow reshapes value chains and shifts production sites, hubs, and modes and channels of communication. In doing so, it also increases encounters and opportunities, as well as confrontations, rejection and enclaves.

The disparate effects of globalisation and technological change were among the findings shared by OECD countries and outlined in the Declaration on Policies for Building Better Futures for Regions, Cities and Rural Areas at the Ministerial Meeting of the Regional Development Policy Committee in Athens in 2019. However, current events demand that we work more deeply and effectively on this issue. As a result of the crisis affecting the world economy, decisions made by public and private actors must now be taken in a context of "radical uncertainty" (Knight, 1921; OECD, 2020a). ${ }^{5}$ This concerns not only the scale of the economic and social shock and the level of response to it, but also the driving forces and organisation of human activities themselves. Our renewed awareness of the risks associated these ways of life (globalised, largely urbanised but territorially diverse, consuming non-renewable and often unequally distributed resources) could present an opportunity to transform these ways of life for the better. Despite benefiting from renewed attractiveness in counterpoint to strict market logic, public decision-making in this context is not simple: it must respond to the enormous short-term challenges of supporting health care spending, companies and the most vulnerable groups, while committing to ambitious long-term programmes underpinned by ecological transition. Public decision-making must both "re-distribute" and "pre-distribute" (Subramanian, 2020) by influencing the outcome of market activity.

However, public decision-making does not emanate from a single actor, but from the interweaving of national government and local authority action and, in Europe, from the supranational level (OECD, 2020b). Even if coordinating this multilevel action is a challenge, the plurality of commitments presents an opportunity, and not just because of the co-financing solutions it allows. In a context of radical uncertainty,

\footnotetext{
${ }^{5}$ The latest OECD Economic Outlook report takes into account the high level of uncertainty and thus distinguishes between two scenarios for establishing its outlook, see https://www.oecd.org/newsroom/global-economy-faces-a-tightrope-walk-to-recovery.htm.
} 
no actor is omniscient and no one can rely solely on standard normative principles, without significant risks to public policy. Each contributes their knowledge and resources - public actors, businesses, and associations of all kinds and individuals - to action that cannot be uniform. The crisis has had a different impact on different territories; the possibilities for response and the needs to be met are not the same everywhere. Factors that characterise both the impact and the pathways for change include regional sectoral specialisation and greater or lesser sensitivity to international trade and travel (OECD, 2020c); the size of local businesses (Card et al., 2018); access to infrastructure and services (Brezzi and Luongo, 2016); and urban concentration (OECD, 2020c).

To these economic considerations, we should add elements such as social cohesion, social capital, and people's trust in others and in institutions, which are more difficult to assess and yet even more decisive as regards a territory's capacity to respond to the crisis and its consequences. These aspects are also geographically determined. These factors, like those above, explain disparities that pre-date the pandemic, which the 2008 crisis - and in some cases the responses to it - also helped shape. They help to explain the geography of discontent that has emerged in France, as elsewhere in many OECD and non-OECD countries (Rodríguez-Pose, 2017; McCann 2020; Algan et al., 2020).

How does the current crisis disrupt the status quo for territories immersed in globalisation, their businesses and their inhabitants? How does it transform their relationship with pre-existing megatrends other than economic globalisation: digitalisation, climate change and demographic change (OECD, 2019a)? ${ }^{6}$ And how does it affect territorial policy agendas (by influencing those already underway and by proposing innovations)? It is beyond the scope of this report to answer such broad questions. Nevertheless, we aim to contribute by shedding light on the role of regions in globalisation.

Globalisation is currently being called into question. What is the basis for this challenge? Global value chains have driven industry segments to specialise and (international) just-in-time management to become mainstream to optimise the international fragmentation of production and consumption. The pandemic raises difficult questions for this form of globalisation, in particular its implications for dependence in relation to essential products. Today, some are calling for the "reshoring" of businesses and activities that are deemed vital, as well as improved stock policies. Sectoral recovery plans, in particular those backed by the French State (automotive, aeronautics, health), coupled with the recovery plans created by the regions, have been drawn up along these lines, re-examining businesses' capacity to reinvest at the local level. ${ }^{7}$ In addition, questions are being asked about the environmental impact - particularly at the local level - of organising production based on the performance/cost rationale, which typically ignore negative externalities such as carbon dioxide emissions from transporting goods or indeed tourists.

The dominance of international markets over local needs when deciding which specialisations are deemed relevant is also being challenged, as it can put strain on the local economic ecosystem, sometimes without consultation, and occasionally threaten biodiversity and landscape quality. Finally, strong civil society movements stress that the growth resulting from this globalisation dynamic does not always lead to more balanced development between people and territories, but is perceived as participating in the inequitable trend of an ever-increasing concentration of wealth and opportunity.

One counterargument could be that, in parallel to all these shortcomings and disadvantages, internationalisation can have positive local spill over effects (Lembcke and Wildnerova, 2020) ${ }^{8}$ in terms of skills and innovation, improve the employment situation, provide access to key resources, infrastructure and services, and lead to better territorial distribution of economic activity by avoiding, for example, the

\footnotetext{
${ }^{6}$ OECD member countries highlighted these megatrends during the fourth Ministerial Meeting of the Regional Development Policy Committee in Athens, in March 2019.

${ }^{7}$ The inter-communal territories (Public Establishment for Intercommunal Cooperation - EPCI), which are responsible for economic development, are also involved in diagnostic studies to assess their economic base's degree of dependency through purchase mapping.

${ }^{8}$ Lembcke and Wildnerova (2020) show that local small and medium-sized enterprises (SMEs) benefit more in terms of productivity from foreign direct investment in their region when this involves an industry segment that differs from their own.
} 
industrial overconcentration that some French regions experienced in the twentieth century, with all the associated disadvantages for the environment and quality of life (OECD, 2020f).

A second counterargument could be that internationalisation is not an end in itself, and instead the crisis might lead to a switch in objectives from "ever more" (savings, exports, foreign direct investment, tourists) to "much better" (for people, local businesses, the establishment of decision-making hubs in international firms) (Giroud, 2013; Bassanini et al., 2017), especially with regard to the urban-rural balance and the environment.

This win-win scenario for internationalisation and inclusive and sustainable territorial development cannot be achieved "automatically" or even "systemically" through the market alone. Public policy has a critical role, with policy makers well aware that the crisis must not lead to the closure of borders nor the erection of barriers to the movement of people and the international exchange of knowledge and goods. On the basis that it is neither possible nor appropriate to reshore everything and risk the interruption of supply and sharp price increases, a third counterargument suggests that a gradual ${ }^{9}$ and territorially balanced transformation should take into account local characteristics and the existing international links between territories. For example, a decline in global value chains in favour of increased reliance on domestic production could be a double-edged sword: with positive effects on employment but negative effects on consumer prices.

A fourth counterargument stems from the intersection of these phenomena with another major source of disruption, the trend towards digitalisation. The current crisis has strengthened this trend, which accentuates regional differences by transforming production, work, consumption and leisure patterns. Such transformations are particularly evident within the regions themselves, between their urban and rural territories. At present, it is very difficult to predict the outcome, in terms of territorial attractiveness, of automating the least skilled positions in the manufacturing industries that have traditionally been located in sparsely populated areas (given their need for land). Similarly, it is difficult to anticipate the territorial consequences of the mass adoption of remote working. While urban areas had a pronounced advantage, owing to generally superior broadband connections as well as a higher concentration of jobs more easily amenable to remote working, there is scope for expansion of such practices to other places (as mid-sized urban areas) as sustained remote working expands (OECD, 2021). This would call into question the benefit of concentrating key functions in urban centres if workers' desire to reshore for more advantageous conditions (in terms of cost, space and environmental quality) persists beyond the crisis. Transport and broadband infrastructure, which are essentially localised, will be decisive in this respect.

There is, therefore, no universal optimal solution to the implementation of inclusive and sustainable internationalisation policies in the era of the COVID-19 pandemic. At the very least, we can stress that policy objectives must include the control of essential goods and services for the benefit of the territories and their inhabitants. In this regard, local autonomy goes hand in hand with internationalisation through the integration of workers providing essential services: the crisis has led to the awareness that a high proportion of these essential service providers are of foreign origin (Charbit and Tharaux, 2020). Resilient regional development, therefore, requires support for diversity in the provision of supplies, the inclusion of all, and local capacity for innovation that enhances territories' ability to adopt outside innovations and produce new ones. Thus, public action must bring together different dimensions of internationalisation and be based on governance measures that allow coherent and effective internationalisation policies to be implemented.

The first chapter of this report proposes a tool to assess regional globalisation, with a view to facilitating public decision-making. To this end, four families of "international connections" and their representative indicators have been identified: infrastructure, people, knowledge and business. This multidimensional approach has then been applied to the French regions to determine their different

\footnotetext{
${ }^{9}$ As Mouhoud (2020) asserts, it is more likely that there will be a decline in offshoring than strong growth in reshoring (onshoring), at least in the short term.
} 
internationalisation profiles. It is underpinned by the unprecedented collection of data to determine the French regions' position, not only in relation to each other, but also, where data are available, in relation to other European regions and OECD countries.

The second chapter explores the projects contained in the regions' strategic plans. This report is based on the principle that the territories are on the front line. The regions are best placed to envision an approach that goes beyond sectoral and geographically fragmented conceptions and that is able to adapt policies to meet local needs and opportunities in the territory. The regions are also key actors in internationalisation, particularly given their responsibility for economic development. Thus, for the first time, the Regional Plans for Economic Development, Innovation and Internationalisation (SRDEII) - adopted in accordance with the provisions of article 2 of Law No. 2015-991 of 7 August 2015 on the New Territorial Organisation of the Republic - include an "internationalisation" component that covers measures to promote exports and support regional attractiveness. This rationale underpins our focus on these strategic documents (in this case, their first generation) and confirms the relevance of analysing them according to the different dimensions of international connection proposed. We have also added two further dimensions to assess the organisation of regional action:

- approaches to regional strategy integration that link different internationalisation objectives

- multi-actor co-ordination of policy implementation, and in particular of State-region mechanisms for co-ordinating internationalisation policies through different models, especially with regard to business connections.

The conclusion underlines the need to adopt territorialised, informed and complementary (rather than one-dimensional) internationalisation policies that integrate different targets for greater effectiveness. Finally, we propose avenues for reflection to continue this initial work.

This original study is preliminary in several respects and will need to be supplemented:

- Certain data are missing from the comparative statistical analyses.

- The SRDEII analysis, while providing a relevant sample for comparison, will need to be complemented by analysis of short and long-term internationalisation policies in response to the crisis.

- The exploratory presentation of the relations between the institutional actors involved in the internationalisation of territories in France focuses on the regulatory aspects but does not take into account the diversity of ways in which policies are implemented in practice.

More in-depth work, planned in conjunction with France and its National Agency for Territorial Cohesion (ANCT) and with the support of the European Commission, will shed light on good practices and difficulties, based on experience on the ground. 


\section{Methodology and} internationalisation indicators

This chapter aims to answer the following questions:

- What are the relevant themes and indicators to measure the regions' degree and nature of internationalisation and thus assist in policy development?

- Are current measures of regional internationalisation sufficiently well-informed or should they be improved, in particular to promote comparisons between territories and between different time periods?

We respond to these:

- By proposing an original conceptual framework that mobilises indicators on the basis of available data, organised around the four pillars identified to reflect the different dimensions of regional internationalisation:
○ infrastructure connections
- human connections
○ knowledge connections
○ business connections.

- By specifying data collection issues, to provide useful suggestions for improving the provision of information to those national statistical authorities interested in regional internationalisation. By providing a new set of indicators to measure the level of internationalisation of OECD regions (at the sub-national level).

This quantitative section benefited from contributions from the ANCT (from its departments at the General Directorate for Operational and Strategic Support, in particular its Territorial Analysis and Diagnostics Unit, its National Territorial Observatory and departments at the General Directorate for Territories and Rural Areas) and Business France.

These exchanges contributed to the methodology presented in this report, as did the previous work of the OECD Working Party on Territorial Indicators, which brings together experts from all OECD and partner countries to carry out statistical work on measuring and analysing regional economies. ${ }^{10}$

\footnotetext{
${ }^{10}$ See the previous report The Internationalisation of Regions presented in October 2019 to the Working Party on Territorial Indicators of the OECD's Regional Development Policy Committee.
} 


\subsection{A proposed framework for analysing the internationalisation of regions}

The following indicators provide an overall framework for assessing regional internationalisation. They offer an overview of a region's current level of international connections based on the four pillars:

- infrastructure connections

- human connections

- knowledge connections

- business connections.

This chapter aims to take stock of the available indicators that describe regions' current level of international connections. We also suggest additional indicators to consolidate a holistic view of the phenomenon of regional internationalisation.

Furthermore, the indicators presented below do not capture some key factors in terms of the "potential" for internationalisation, which have a major impact on attractiveness. These factors include legal frameworks and the national institutional environment, regional institutional quality, and ease of doing business, to cite dimensions that capture the interactions between a region and globalisation.

\subsubsection{Infrastructure connections}

Infrastructure connections are the physical connections a region offers to its potential international partners. The existence and characteristics of infrastructure connections condition the existence and intensity of the various flows that link regions to their international partners, whether human, financial, cargo or data flows.

The OECD does not collect comprehensive regional infrastructure data, but does have some specific indicators, such as the share of households with broadband connectivity at the territorial level 2 (TL2) regional level. ${ }^{11}$

At the European level, however, Eurostat has data on infrastructure and air, rail, sea and road traffic that we have been able to use.

This data allowed us to select the following indicators:

(i) On access to the road network:

- motorway and dual carriageway accessibility

- motorway accessibility

(ii) On access to rail and airport hubs:

- $\quad$ station accessibility

- airport accessibility

(iii) On logistics:

- land-based logistics: number of warehouses of more than $5000 \mathrm{~m}^{2}$

- land-based logistics: share of foreign loading and unloading in warehouses**

\footnotetext{
${ }^{11}$ In any economic analysis at the sub-national level, the choice of territorial unit is paramount. The OECD has therefore drawn up a two-level map of regions in each member country. The upper level, territorial level 2 (TL2), is equivalent to the French regions and includes 394 large regions; while the lower level, territorial level 3 (TL3), is equivalent to the French departments and includes 2258 small regions. All territorial units fall within national borders and most often correspond to administrative divisions. This classification (which, for European countries, largely coincides with that of Eurostat, Nomenclature of territorial units for statistics (NUTS) 2 and NUTS 3) facilitates the comparison of geographic groupings of the same territorial level. The two levels selected, which are officially recognised and relatively stable in all member countries, also serve as a framework for the implementation of regional policies in most countries. OECD Territorial Grid (pdf): http://www.oecd.org/governance/regional-policy/42392313.pdf.
} 
- maritime logistics: volume and share of international sea freight

(iv) On digital coverage and usage:

- fibre optic coverage

- households with broadband access

- Internet use: sale of goods and services

- Internet use: Internet banking

- Internet use: participation in social networks.

\subsubsection{Human connections}

People, and more specifically visitors and migrants, are an important dimension of internationalisation.

Human connections are therefore measured using migration data: not only migrants' length of stay, but also the foreign-born share of the population. The OECD has data on the presence and integration of migrants, mainly at NUTS 2 level with more partial data at the NUTS 3 level (equivalent to the French departments).

Human connections also cover tourism. The OECD does not publish regional tourism data for its member countries but relies on the work of the United Nations Educational, Scientific and Cultural Organization (UNESCO) (e.g. number of World Heritage sites); the European Commission's Joint Research Centre (JRC) (e.g. the indicator on vulnerability related to exposure to tourism) (Batista e Silva et al., 2018); ${ }^{12}$ and Eurostat (e.g. number of overnight tourist stays). In addition, many member countries, such as France, Spain and the United Kingdom, collect useful information on the number of arrivals and employment in this sector at the sub-national level (OECD, 2016).

\subsubsection{Knowledge connections}

Knowledge flows are a crucial aspect of internationalisation and - in a digital, rapidly changing society they strongly contribute to the success of individual, business and territorial activities. In principle, knowledge connections include many aspects, although the existing literature provides few indicators to enable the comparison of regions from one country to another. Available indicators include patent production, research and development (R\&D) spending, and measures relating to knowledge-intensive industries. The core hypothesis of this pillar is that the most innovative sectors create more international links. Empirical research shows that increased access to foreign markets increases stimulus for innovation, which in turn increases productivity and ultimately market size (Lileeva and Trefler, 2010). In addition, research and development enable businesses to better withstand foreign competition (Hombert and Matray, 2015). The number of co-patents filed by partners in different countries is one of the best measures because it is inherently linked to knowledge flows (at least between inventors).

\subsubsection{Business connections}

Business ties are key to globalised networks, and are often the only aspect measured. They materialise primarily through trade, imports and exports to final or intermediary destinations. Multinational enterprises are driving both globalisation and the resulting international fragmentation of production. Demand is therefore increasing for better measures of the actual scale of their activities (including their subsidiaries abroad and their links with other independent contractors). Multinationals also play an ever-increasing role

\footnotetext{
${ }^{12}$ Regional vulnerability to tourism is measured by a region's exposure to shocks in the tourism sector and incorporates two concepts: the tourism intensity index in each region, calculated from the location quotient of the number of tourists relative to the population; and regional seasonality, based on monthly data obtained from big data. Each region is scored from 1 to 4 for each indicator (intensity and seasonality) and the vulnerability of tourism is calculated as the product of the respective scores, ranging from 1 to 16 .
} 
in the development of global value chains, which are not limited to trade and foreign direct investment (FDI) alone: they have a direct and global effect on the organisation of production systems and related operations (R\&D, marketing, parent company, etc.). The OECD has national rather than sub-national data on global value chains and value-added trade.

Overall, comparable statistical indicators on business connections at the regional level are scarce. Currently, the most relevant measures relate to a region's trade, such as the share of the regional economy in the "tradable goods" sectors (see definition Box 1.3), the level of imports/exports and the level of FDI. While some countries (including France) have regional data on imports and exports of goods, more than half of OECD countries do not provide this information. The possibility of collecting additional comparative data at the regional level is being studied.

\subsection{Proposed methodology for measuring regional internationalisation}

\subsubsection{Internationalisation indicators}

The list of indicators set out in Table 1.1 below is intended to provide consistent, comparable data and a concrete measure of the internationalisation of regions. It will also enable regions to compare their level of internationalisation.

In Table 1.1. , the symbol ** identifies the benchmark indicators (see Identifying baseline indicators), and the symbol ${ }^{* \star *}$ means that these indicators are disaggregated by nationality or partner country.

\section{Table 1.1. Internationalisation indicators}

\begin{tabular}{|c|c|c|c|}
\hline Indicators & Source & Geographic coverage & Period \\
\hline \multicolumn{4}{|l|}{ 1. Infrastructure connections } \\
\hline Motorway and dual carriageway accessibility (Source: CGET) & Observatory & France, TL2, municipalities & 2009 \\
\hline Motorway accessibility & $\mathrm{RCl}(\mathrm{EC})$ & EU 28 & 2016 \\
\hline Station accessibility & $\mathrm{RCl}(\mathrm{EC})$ & EU 28 & 2014 \\
\hline Airport accessibility ** & $\mathrm{RCl}(\mathrm{EC})$ & EU 28 & 2016 \\
\hline Fibre optic coverage ** & OECD & 18 countries, TL2, FUA & 2016 \\
\hline Households with broadband access ** & OECD & OECD countries, TL2 & $2008-19$ \\
\hline Internet use: sale of goods and services ** & Eurostat & EU 28 & $2011-19$ \\
\hline Internet use: Internet banking & Eurostat & EU 28 & $2011-19$ \\
\hline Internet use: participation in social networks ${ }^{* *}$ & Eurostat & EU 28 & $2011-19$ \\
\hline Land-based logistics: number of warehouses of more than $5000 \mathrm{~m}^{2 * *}$ & $\begin{array}{l}\text { State owned } \\
\text { enterprises }\end{array}$ & Mainland France & 2014 \\
\hline $\begin{array}{l}\text { Land-based logistics: percentage of foreign loading and unloading in } \\
\text { warehouses ** }\end{array}$ & $\begin{array}{l}\text { State owned } \\
\text { enterprises }\end{array}$ & Mainland France & 2014 \\
\hline Maritime logistics: percentage of international sea freight & Eurostat & EU 28 & 2018 \\
\hline \multicolumn{4}{|l|}{ 2. Human connections } \\
\hline \multicolumn{4}{|l|}{ 2.1 Tourism } \\
\hline Number of tourist accommodation establishments (source EU) & Eurostat & EU 28 & $2000-18$ \\
\hline Tourism (number of beds per 1000 inhabitants) source EU ** & Eurostat & EU 28 & $2000-18$ \\
\hline Overnight tourist stays (foreign and domestic) & Eurostat & EU 28 & $2000-19$ \\
\hline Overnight stays per $\mathrm{km}^{2}$ (foreign and domestic) & Eurostat & EU 28 & $2000-18$ \\
\hline Overnight stays per 1000 inhabitants (foreign and domestic) & Eurostat & EU 28 & $2000-18$ \\
\hline Share of overnight stays by foreign visitors ** & Eurostat & EU 28 & $2000-18$ \\
\hline Tourism intensity & JRC & EU 28 & 2014 \\
\hline Share of foreign owners (main residence) & Observatory & France, TL2 & 2015 \\
\hline \multicolumn{4}{|l|}{ 2.2 Share of migrants } \\
\hline Share of immigrant population (Total, EU, non-EU) ${ }^{* * * *}$ & OECD & 28 countries, TL2 & 2015 \\
\hline Share of immigrants by duration of stay ( $<>10$ years) & OECD & 28 countries, TL2 & 2015 \\
\hline
\end{tabular}




\begin{tabular}{|c|c|c|c|}
\hline Indicators & Source & Geographic coverage & Period \\
\hline Difference in the percentage of women (immigrant and native-born) & OECD & 28 countries, TL2 & 2015 \\
\hline \multicolumn{4}{|l|}{$2.3 \mathrm{Immigrants}$ by education and position in the labour market } \\
\hline Share of immigrants (EU, total) with higher education & OECD & 28 countries, TL2 & 2015 \\
\hline $\begin{array}{l}\text { Difference in employment rates (migrant and native-born population, 15- } \\
64 \text { ) }\end{array}$ & OECD & 28 countries, TL2 & 2015 \\
\hline Share of immigrants in highly skilled employment ** & OECD & 28 countries, TL2 & 2015 \\
\hline Share of immigrants with higher education in low-skilled jobs & OECD & 28 countries, TL2 & 2015 \\
\hline \multicolumn{4}{|l|}{ 3. Knowledge connections } \\
\hline International students ${ }^{* * * *}$ & Observatory & France, TL2, municipalities & 2015 \\
\hline Foreign teacher-research workers & Observatory & France, TL2 & \\
\hline International collaboration in patents (co-inventors) ${ }^{* *}$ & OECD & $\begin{array}{l}\text { OECD countries - TL2, } \\
\text { TL3 }\end{array}$ & $1990-2015$ \\
\hline Share of foreign R\&D personnel ** & Observatory & France, TL2 & 2015 \\
\hline R\&D: personnel and expenditure & OECD & OECD Countries - TL2 & $2000-17$ \\
\hline Employment in knowledge-intensive sectors & OECD & EU countries, TL2 & $2008-18$ \\
\hline Innovation hubs & .. & .. & .. \\
\hline Cultural goods (museums, heritage, festivals, etc.) & .. & .. & .. \\
\hline \multicolumn{4}{|l|}{ 4. Business connections } \\
\hline Share in tradable sectors (gross value added and employment) ${ }^{* *}$ & OECD & $\begin{array}{l}\text { OECD countries - TL2, } \\
\text { TL3 }\end{array}$ & $2000-17$ \\
\hline Imports and exports of goods (final and intermediate) ${ }^{* * *}$ & Customs & France, TL2 & 2014-18 \\
\hline Position of regions in global value chains & .. & .. & .. \\
\hline Share of employment in foreign-owned firms ** & Observatory & France, TL2 & 2015 \\
\hline Share of employment in international firms & Observatory & France, TL2 & 2015 \\
\hline FDI (number of investment projects) ** & Business France & France, TL2 & 2014-18 \\
\hline Jobs created or maintained through FDI $* * \star *$ & Business France & France, TL2, municipalities & 2014-18 \\
\hline
\end{tabular}

Source: Prepared by the authors.

\subsubsection{Identifying baseline indicators}

We have identified baseline indicators to simplify the explanation and use of this methodology. These indicators were selected according to different criteria:

(i) The indicator directly captures the international relationship (i.e. it is a direct indicator), e.g. the share of international students or international trade, or enhances the capacity of French regions to open up to international flows, e.g. the share of employment in tradable sectors.

(ii) The indicator does not correlate with the direct indicators identified or provides specific information regarding the internationalisation of the region. To illustrate this: an indicator that is highly correlated with the number of inhabitants in the region provides little additional information and is therefore likely to be excluded from the list of baseline indicators.

(iii) The availability of recent data, especially when the indicator value changes rapidly (such as fibre optic coverage).

Thus, for the infrastructure indicators, the index "population living within a $120 \mathrm{~km}$ radius that can access railway stations within 90 minutes" (where the average for the EU 28 is 100) is strongly correlated with "number of flights accessible in 90 minutes by car." The latter indicator alone will therefore be used as the baseline indicator. 
Similarly, for Internet use, "use to sell goods and services" will be selected in preference to Internet banking. Each indicator has been assessed in this way and is recorded in the Excel file for the internationalisation database. ${ }^{13}$

\section{Figure 1.1. Example of the choice of baseline indicators for the French regions}

a. Access to long-distance infrastructure

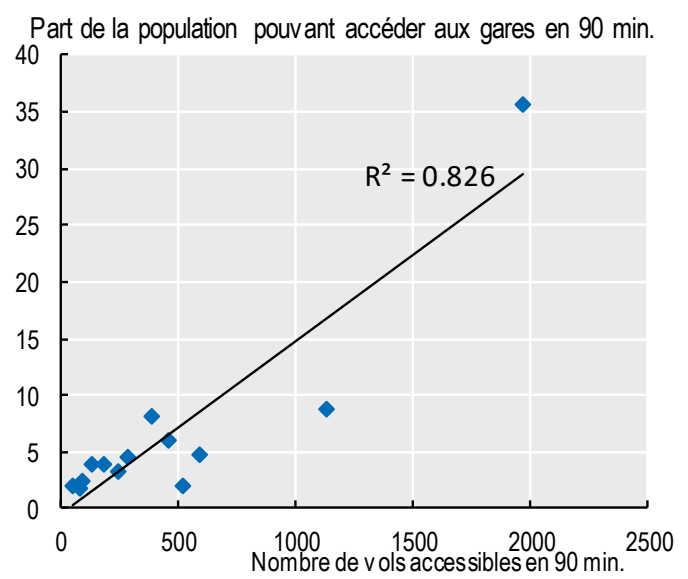

b. Internet use

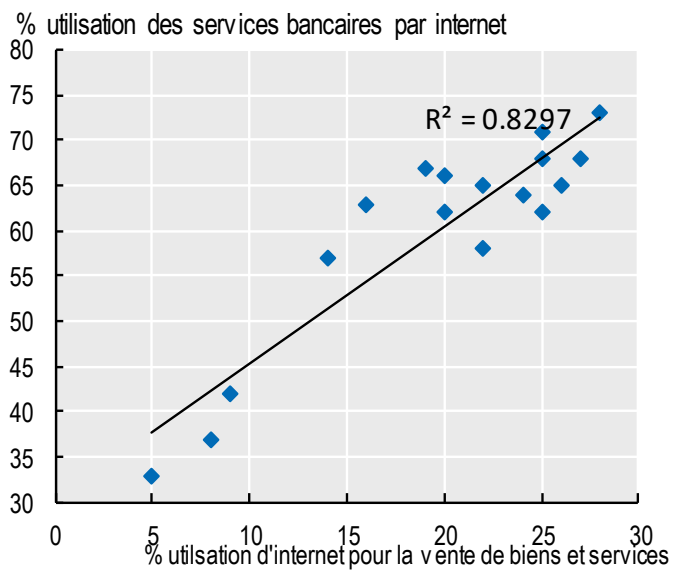

The following baseline indicators were selected using this method:

\section{For infrastructure connections:}

- airport accessibility (number of passenger flights accessible within 90 minutes by car)

- fibre optic coverage (percentage of buildings covered (fibre to the home - FTTH)

- households with broadband access as a percentage of the total number of households

- Internet use:

- percentage of individuals buying/selling goods and services over the Internet in the year

- percentage of individuals participating in online social networks in the year

- Land-based logistics:

- number of warehouses of more than $5000 \mathrm{~m}^{2}$

- share of foreign loading and unloading in warehouses of the total loading and unloading figure.

\footnotetext{
${ }^{13}$ The Excel file containing data on regional internationalisation is available at the following link: http://stats.oecd.org/wbos/fileview2.aspx?IDFile=15f69bbd-918d-4e48-b488-0678edcd1f51.
} 


\section{Box 1.1. Port activity, a key element of regional development}

Sea and river port activity represents a key source of economic development in the territories.

French maritime traffic reached 297.5 million tonnes of cargo handled at mainland ports in 2018. Three regions account for $75 \%$ of the volume handled nationally: Normandy $(30 \%)$, the Sud region $(25 \%)$ and the Hauts-de-France region (20\%). Marseille is the leading French port with 75.7 million tonnes, ahead of Le Havre (64.9 million tonnes), Dunkirk (41.1 million tonnes) and Nantes Saint-Nazaire (31.9 million tonnes). The European market accounts for $31.3 \%$ of the volume traded nationwide, and for more than $99 \%$ at the ports of Calais and Cherbourg. The non-European market accounts for more than $75 \%$ of activity at the ports of Le Havre, Marseille and Nantes Saint-Nazaire.

\section{Figure 1.2. French seaport activity by partner zone, 2018}

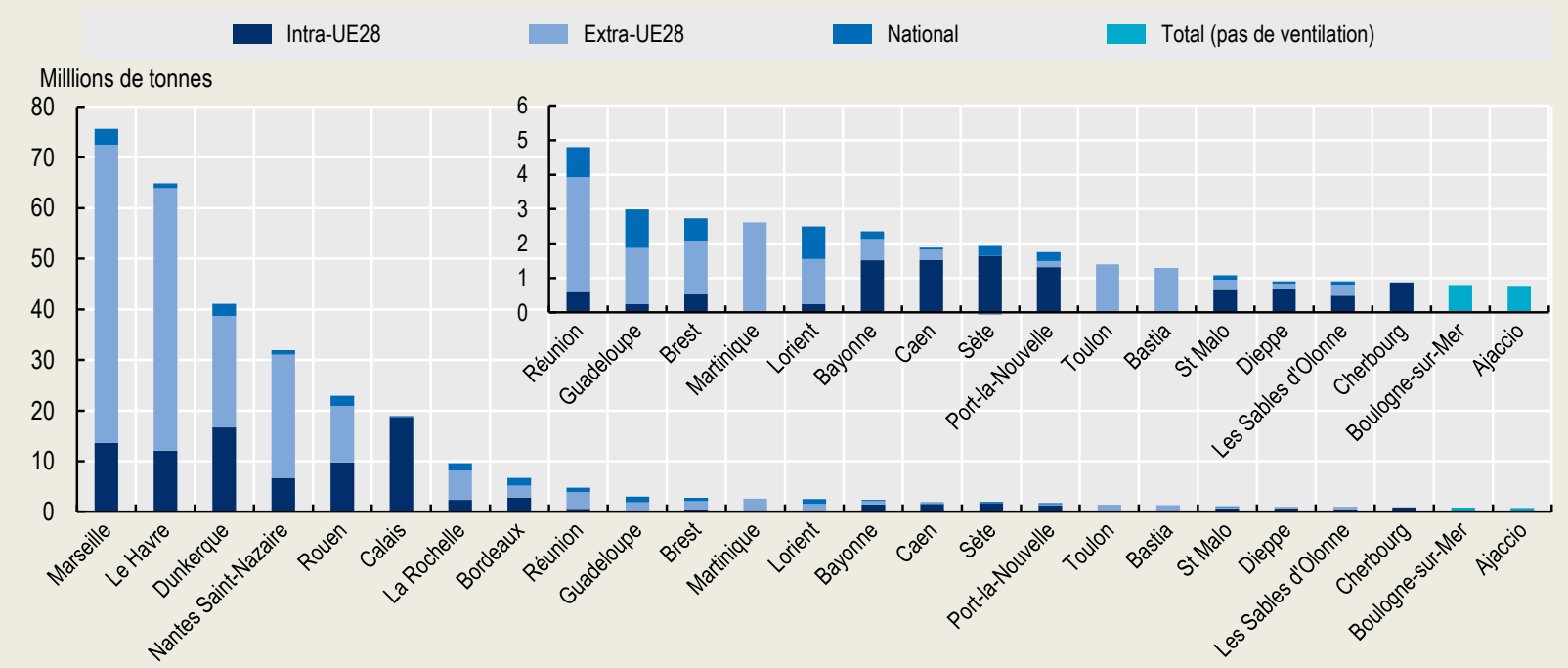

Source: Eurostat

River cargo traffic in France accounted for about $20 \%$ of French seaport traffic in 2018. River port activity in the Grand-Est and Île-de-France regions is at the same level as seaport activity in Nouvelle-Aquitaine. The same is true for river port activity in the Auvergne-Rhône-Alpes region in comparison with the seaports of Reunion and Guadeloupe. 


\section{Figure 1.3. French seaport and river port activity, 2018}

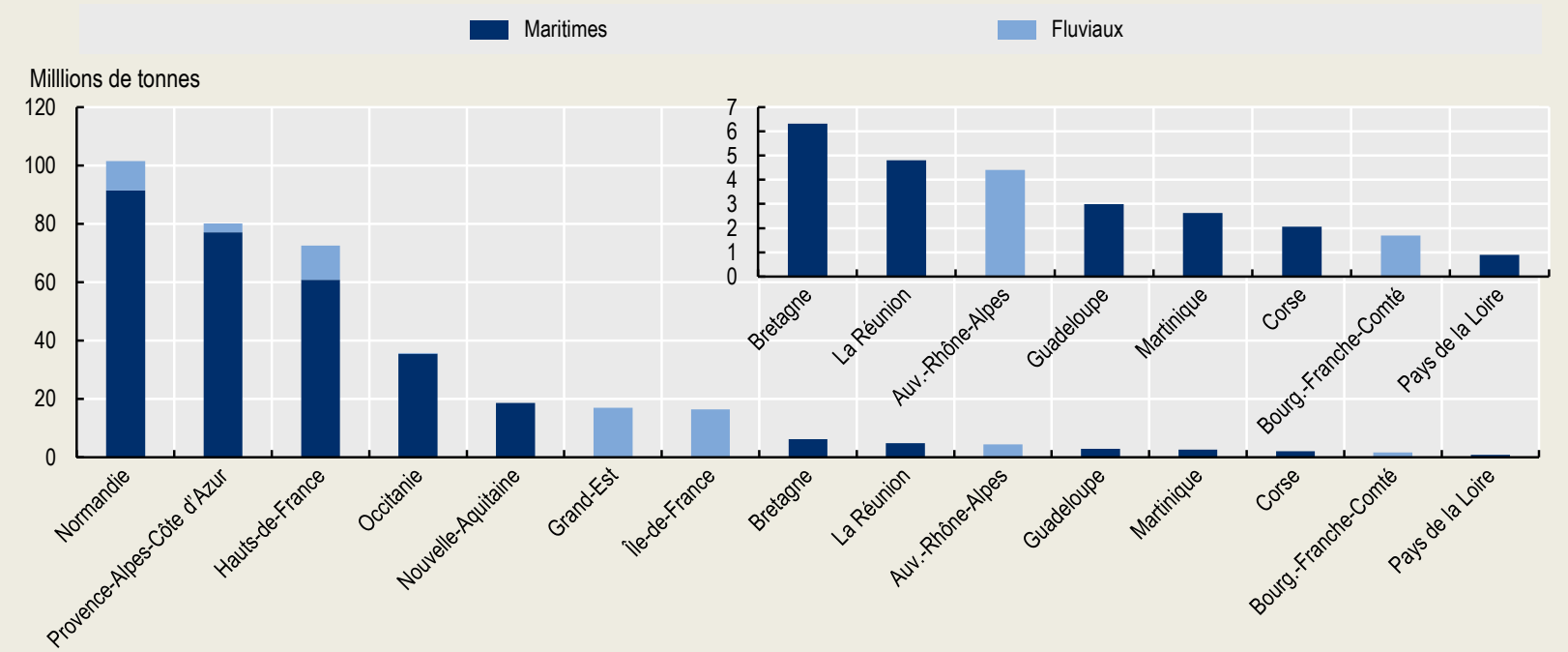

Source: Authors' calculations, based on data from Voies Navigables de France (VNF) and Eurostat.

\section{For human connections:}

- Tourism:

- number of beds in hotels or other types of accommodation per 1000 inhabitants) (available time series 2000-19)

- overnight stays by foreign visitors as a percentage of total overnight stays in hotels or other types of accommodation.

- Immigrants:

- immigrant population as a percentage of the total population (data available by country of origin) (see definition in Box 1.3)

- share of immigrants in highly skilled employment of the total number of immigrants 


\section{Box 1.2. Regional air traffic}

In France, approximately 193 million passengers in total travelled by plane over the three years from 2017 to 2019 , of which $68 \%$ took international flights. The Île-de-France region accounted for nearly $55 \%$ of passenger numbers, $80 \%$ of whom were international. Only the Centre-Val de Loire region had a greater share of international flights, but with "only" 30000 passengers on average.

\section{Figure 1.4. Regional air passenger traffic by destination, 2017-19 average}

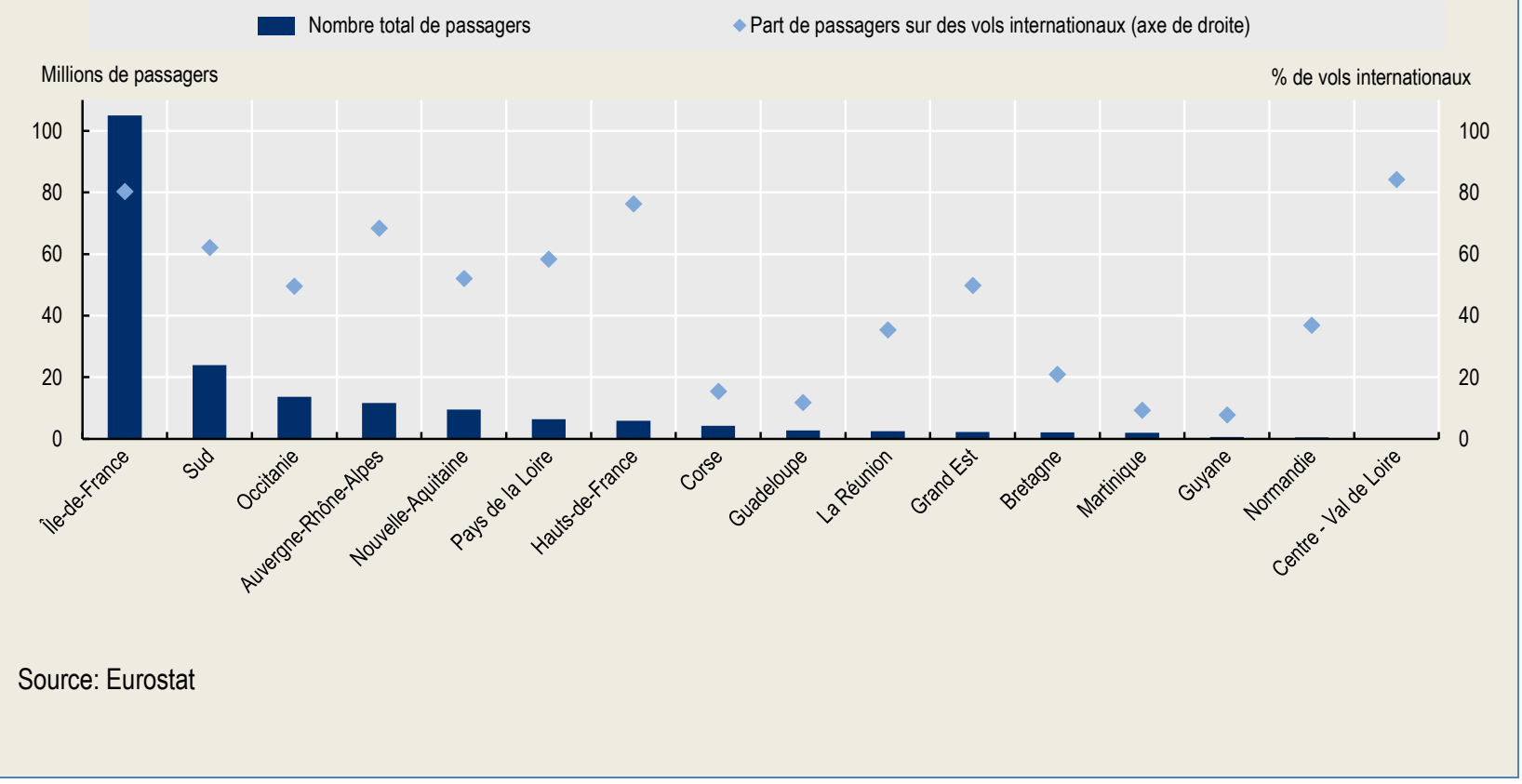

\section{For knowledge connections:}

- international students as a percentage of the total number of students (data available by country of origin)

- international patent collaboration (share of co-patents filed with a foreign inventor as a percentage of total co-patents) (available time series 2000-15)

- share of foreign R\&D personnel as a percentage of total R\&D personnel.

\section{For business connections:}

- share in tradable sectors (gross value added and employment) (see definition in Box 1.3)

- imports and exports of goods (final and intermediate) (time series available 2013-18, by partner country).

- Foreign direct investment:

- number of investment projects (time series available 2014-18, by country of origin)

$\circ$ jobs created or maintained through FDI (time series available 2014-18, by country of origin). 


\section{Box 1.3. Definitions}

The immigrant population is defined by place of birth. Unlike citizenship, this criterion does not change over time and is not subject to differences in legislation in different countries; it is therefore more suitable for international comparisons. Thus, the terms "foreign-born" and "immigrant" are used interchangeably in this report. While being the least biased, this criterion has limitations and can sometimes lead to under or over-statement of the immigrant population at the regional level. For example, it could include foreign-born people who are, nonetheless, citizens.

According to the OECD Regional Outlook 2016, tradable sectors are defined as agriculture, industry, information and communication, financial and insurance activities, and other services. Non-tradable sectors include construction, distributive trade, repairs, transport, accommodation, food services activities, real estate activities, business services and public administration.

The classification of tradable and non-tradable sectors requires compromise because economic data for OECD regions are only available for up to ten industry groups. As most physical goods can be shipped relatively easily, manufacturing, production and resource extraction are considered tradable sectors. Conversely, non-tradable services generally include public services, education, health care, the construction sector and retail. A growing range of business and technical services are becoming increasingly tradable, but a large percentage remain local. For example, public relations or marketing agencies have a global reach, lawyers much less so and cleaning services are clearly provided locally and non-tradable. Hotels and restaurants are categorised as non-tradable because, although tourism is a major contributor to this type of trade in some regions, these industries provide mainly domestic or even only local services.

Source: OECD (2018), Productivity and Jobs in a Globalised World: (How) Can All Regions Benefit?, http://dx.doi.org/10.1787/9789264293137-en.

\subsection{Position of the French regions according to the internationalisation indicators}

In Figure 1.6, the length of the petals represents the region's position among the French regions for each baseline indicator: it extends towards the edge of the circle when a region is first for a given indicator and towards the centre of the circle when it is last. For better readability, only three indicators have been selected for each of the four connection types. Due to the lack of data for some indicators, these have been adapted according to Table 1.2. This visualisation makes it possible to identify particular profiles as regards the regions' position in terms of internationalisation:

- Regions connected to the international community due to their geographic location, such as Grand-Est and Hauts-de-France, which are border regions with strong links to their neighbouring countries. These regions perform well on a wide range of internationalisation indicators. For example, $8 \%$ of international students in the Grand Est region are German and nearly 30\% of the jobs created or maintained through FDI come from Germany. Similarly, the Hauts-de-France region exports $20 \%$ of its goods to Belgium. This geographic proximity allows trade in goods and exchange in innovative sectors, with R\&D and patenting carried out in co-operation with foreign inventors.

- Regions that are more focused on a single dimension of internationalisation, such as Brittany and the Pays de la Loire region, which welcome tourists and skilled migrants; or Normandy, where the value of importing and exporting goods as a percentage of gross domestic product (GDP) is 
the highest among French regions; or the Auvergne-Rhône-Alpes region, which attracts many foreign research workers and foreign investment flows; or the Sud Region, which is consolidating its tourism offer with strong migrant, diaspora and international student populations.

- The overseas regions also have distinct profiles when it comes to internationalisation, with characteristics specific to each, which seem to result much more from the impact of territorial policies than geographic factors (e.g. fibre optics for Reunion, tourism for Martinique and Guadeloupe, and the importance of migration in French Guiana).

- Regions with a less specific internationalisation profile, such as Centre-Val de Loire or Bourgogne-Franche-Comté.

- The Île-de-France region has an exceptional profile compared with other regions:

- First, in terms of labour productivity, France, which had the highest growth in productivity over the 2000-16 period, is the only country where the productivity of all regions diverges from the most productive region: Île-de-France (Figure 1.5).

- Relative to other regions, île-de-France is ultra-connected: for example, it accounts for more than $55 \%$ of passengers travelling by air in France, with $80 \%$ of passengers on international routes; and nearly $84 \%$ of buildings in the île-de-France region had a fibre optic connection in 2020. 
Figure 1.5. Convergence of regions in terms of labour productivity, 2000-16

Classification of major regions (TL2) according to their labour productivity growth, relative to their national frontier (region with the highest productivity at the beginning of the period)

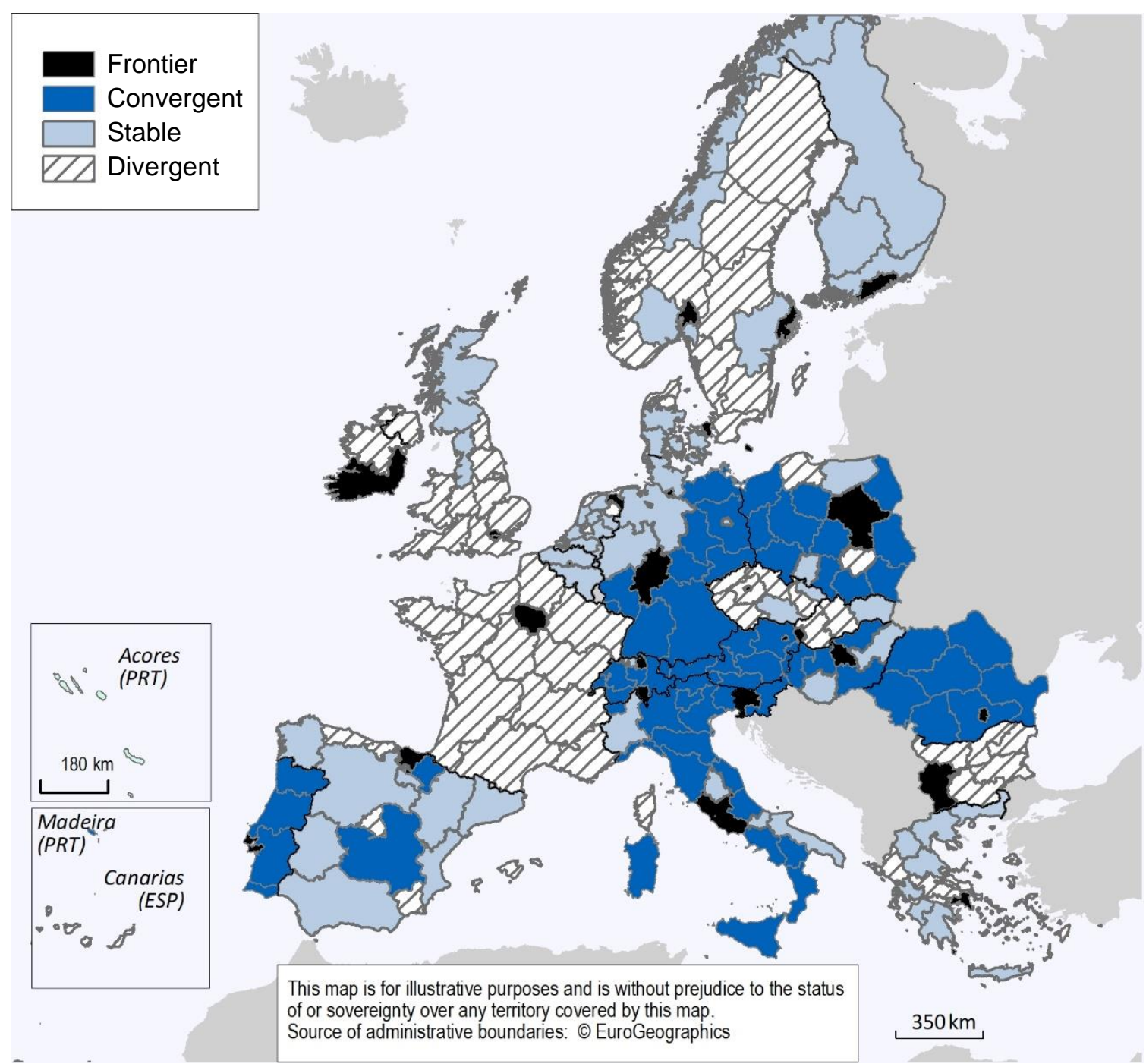

Source: OECD (2016), OECD Regional Outlook 2016: Productive Regions for Inclusive Societies, OECD Publishing, Paris, https://doi.org/10.1787/9789264260245-en. 
Table 1.2. Baseline indicators used in Figure 1.6: Profiles of the French regions

\begin{tabular}{|c|c|c|c|c|}
\hline Pillar & Label on the figure & Indicator & $\begin{array}{l}\text { Mainland } \\
\text { regions }\end{array}$ & $\begin{array}{l}\text { Overseas } \\
\text { regions }\end{array}$ \\
\hline \multirow{3}{*}{$\begin{array}{l}\text { Infrastructure } \\
\text { connections }\end{array}$} & Airport access & $\begin{array}{l}\text { Airport accessibility (number of flights } \\
\text { accessible within } 90 \text { minutes) }\end{array}$ & $x$ & $\mathrm{x}$ \\
\hline & Fibre optic & $\begin{array}{l}\text { Fibre optic coverage (FTTH) as a } \\
\text { percentage }\end{array}$ & $x$ & $\mathrm{x}$ \\
\hline & Social networks & $\begin{array}{l}\text { Percentage of people who use the } \\
\text { Internet to participate in social networks }\end{array}$ & $\mathrm{x}$ & $\mathrm{x}$ \\
\hline \multirow{4}{*}{$\begin{array}{l}\text { Human } \\
\text { connections }\end{array}$} & Tourism & $\begin{array}{l}\text { Tourism, number of overnight stays per } \\
\mathrm{km}^{2}\end{array}$ & $\mathrm{x}$ & $\mathrm{x}$ \\
\hline & Immigrants (presence) & $\begin{array}{l}\text { Immigrants as a percentage of the } \\
\text { population }\end{array}$ & $\mathrm{x}$ & $\mathrm{x}$ \\
\hline & Immigrants (qualification) & $\begin{array}{l}\text { Difference between share of immigrants } \\
\text { and share of native-born population in } \\
\text { highly skilled employment (percentage } \\
\text { points) }\end{array}$ & $\mathrm{x}$ & \\
\hline & Foreign owners & Percentage of foreign owners & & $\mathrm{x}$ \\
\hline \multirow{4}{*}{$\begin{array}{l}\text { Knowledge } \\
\text { connections }\end{array}$} & International students & Percentage of international students & $\mathrm{x}$ & $x$ \\
\hline & Foreign R\&D personnel & Percentage of foreign R\&D personnel & $x$ & $x$ \\
\hline & Co-patent with foreign inventor & $\begin{array}{l}\text { Percentage of patents with foreign } \\
\text { inventors }\end{array}$ & $x$ & \\
\hline & $\begin{array}{l}\text { Employment in knowledge-intensive } \\
\text { market services }\end{array}$ & $\begin{array}{l}\text { Percentage of employment in } \\
\text { knowledge-intensive market services } \\
14\end{array}$ & & $x$ \\
\hline \multirow{4}{*}{$\begin{array}{l}\text { Business } \\
\text { connections }\end{array}$} & Trade & $\begin{array}{l}\text { Imports plus exports as a percentage of } \\
\text { gross domestic product }\end{array}$ & $x$ & $\mathrm{x}$ \\
\hline & Foreign group employment & $\begin{array}{l}\text { Share of employment in foreign-owned } \\
\text { firms }\end{array}$ & $\mathrm{x}$ & $\mathrm{x}$ \\
\hline & FDI & $\begin{array}{l}\text { Number of FDI projects over the 2014- } \\
18 \text { period }\end{array}$ & $\mathrm{x}$ & \\
\hline & $\begin{array}{l}\text { Share of employment in tradable } \\
\text { sectors }\end{array}$ & $\begin{array}{l}\text { Percentage of employment in tradable } \\
\text { sectors }\end{array}$ & & $\mathrm{x}$ \\
\hline
\end{tabular}

\footnotetext{
${ }^{14}$ Share of employment in knowledge-intensive market services (excluding financial intermediation and high-tech services) as a percentage of regional employment, see definition: https://ec.europa.eu/eurostat/statisticsexplained/index.php?title=Glossary:Knowledge-intensive services (KIS).
} 
Figure 1.6. Profiles of the French regions

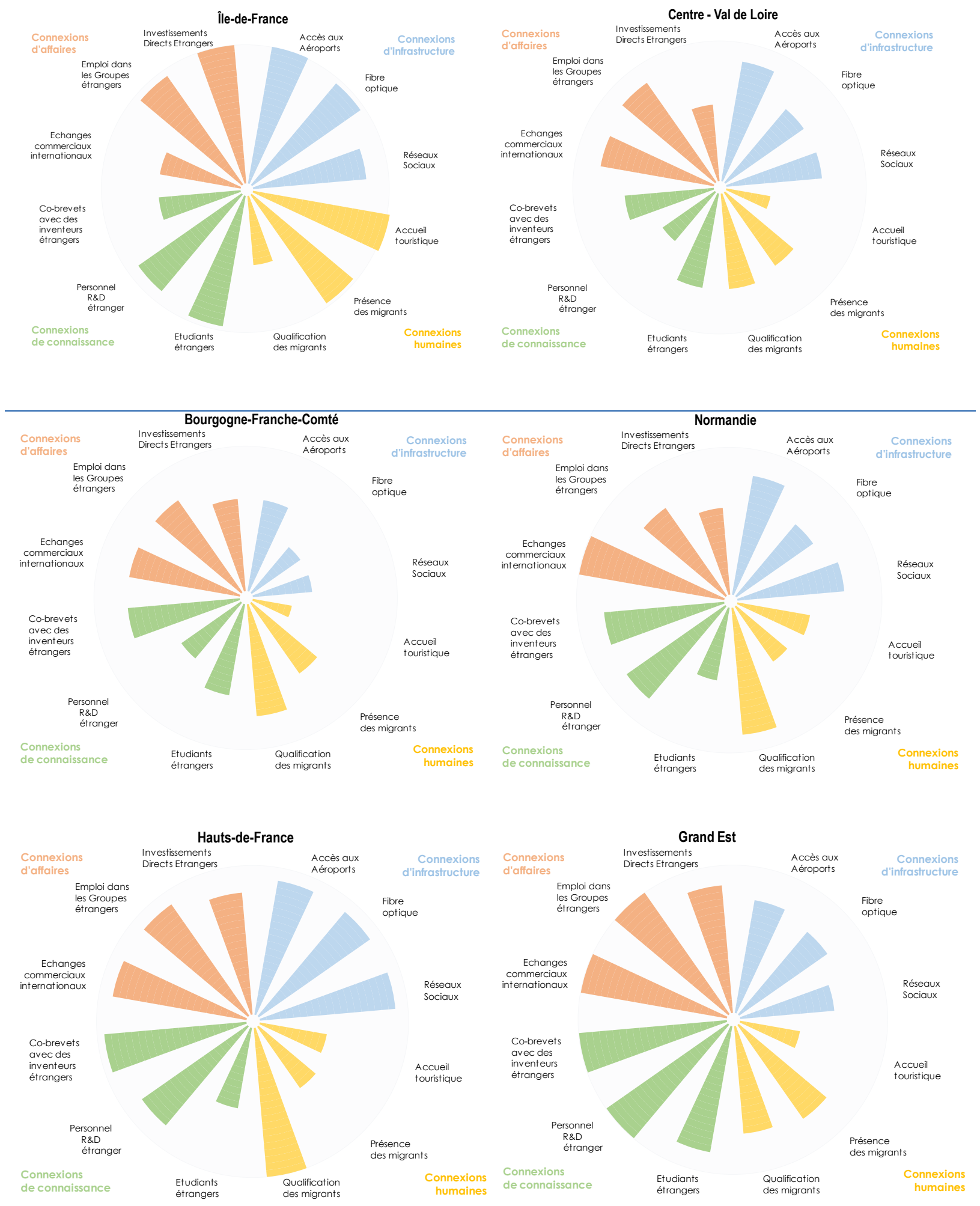




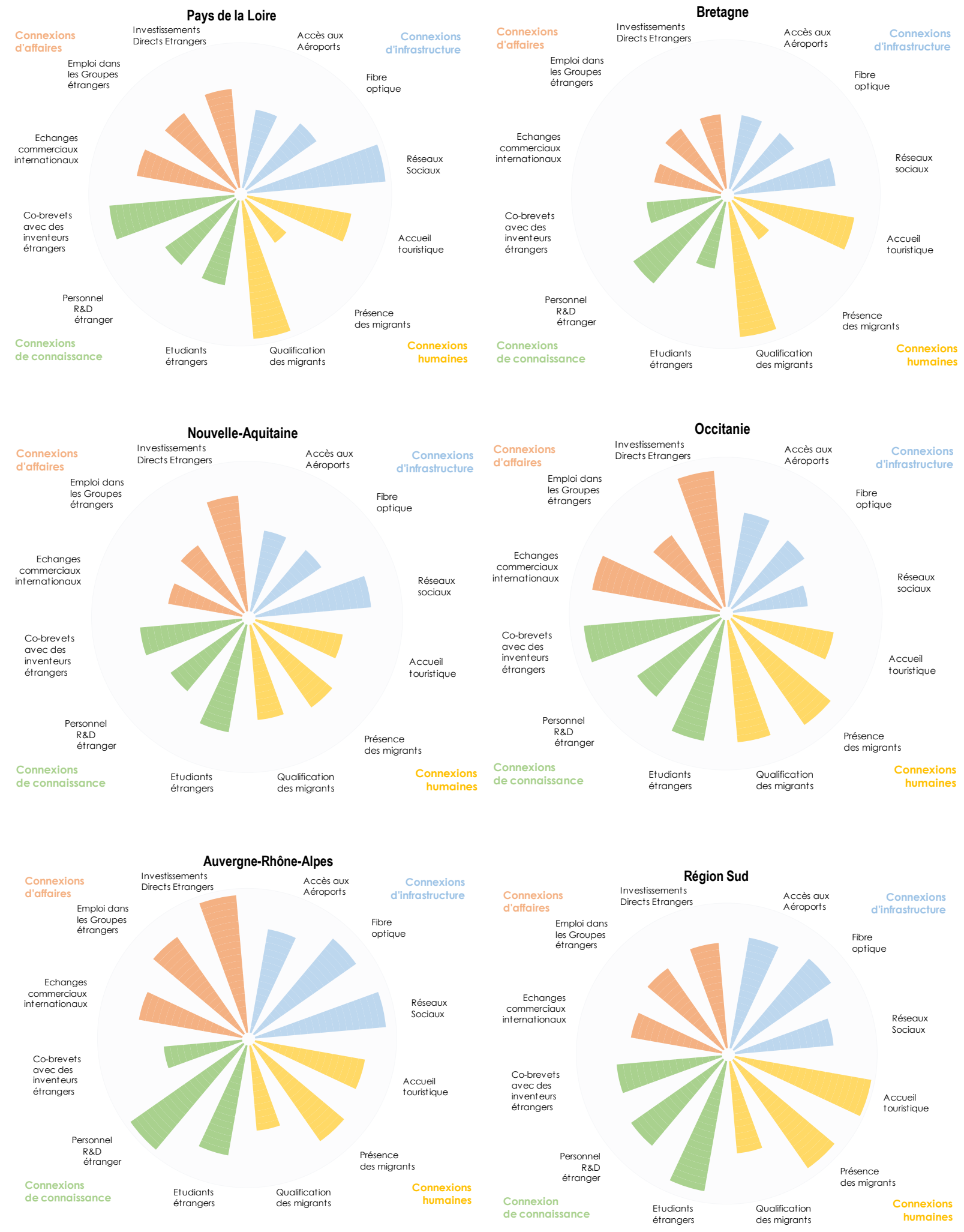



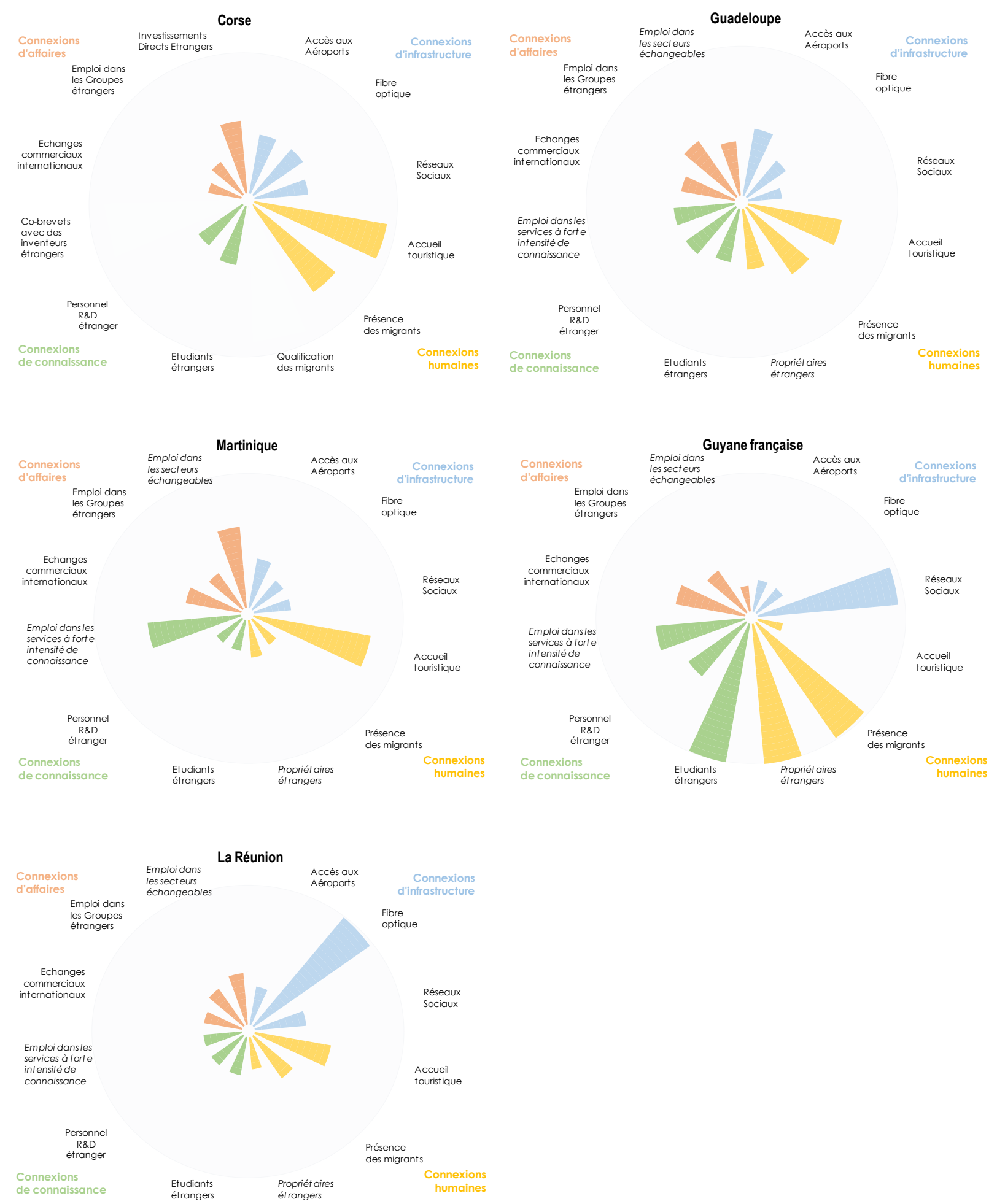

Source: Prepared by the authors. 


\subsection{Discussion of the indicators used and information to be added in the future}

At the national level, frameworks for studying globalisation provide an important foundation of knowledge and experience. However, the use of some indicators at the regional level remains problematic. Understanding of regional integration into global markets would be more accurate - and would better address human, business, knowledge and infrastructure connections - if it included regional indicators on:

- Global value chains. It would be desirable to assess the regions' degree of participation in the production of value added, with the provision of data on re-imports/re-exports, and to distinguish the value added in the region to the share of intermediate imports that go on to be exported.

- FDI, with the measurement of inward and outward investment flows by region and partner country (beyond employment created and/or maintained through FDI, data available for French regions, source Business France).

- Data on innovation hubs and their international collaborations.

- Data on employment in international firms in OECD country regions (beyond the French regions for which data are available).

- The composition of an international tourism database at the regional level, beyond the European Union countries.

- Data on the regional presence of international students and research workers, by nationality (beyond the French regions for which data are available).

- Data on immigrants' financial transfers from host regions to their region and country of origin.

- Knowledge connections could also include indicators relating to cross-border cultural exchanges and cultural amenities (museums, operas, theatres, etc.), which also contribute to territorial internationalisation. ${ }^{15}$

The crisis linked to the COVID-19 pandemic has also highlighted the importance of indicators relating to the regions' dependence and resilience in a globalised economy. Some are already included in the list above (such as measuring regional integration into global value chains). The additional proposals below, while not exhaustive, are avenues for reflection to better contextualise the regions' in relation to their internationalisation strategies:

- data on the diversity of foreign trading partners of businesses in the region

- data on the share of firms directly buying/selling goods and/or services internationally (without the intermediary of, for example, a foreign firm in the region)

- data on the sectoral diversification of the regional economy, including data on the concentration of exports at the company level ${ }^{16}$

- data on the share of businesses - including foreign companies - with their headquarters in the region

- data on foreign companies making new investments, either at the company's current location or in other regions.

\footnotetext{
${ }^{15}$ Such studies could build on the work already carried out by the OECD, whether by creating an international network of museums in partnership with the International Council of Museums (ICOM) or continuing the work carried out on culture and local development as part of the programme of action and co-operation on Local Employment and Economic Development.

${ }^{16}$ In particular, this index makes it possible to measure the dependence of a company's income on a type of exported good or service.
} 


\section{Exploring regional internationalisation policies and governance}

The results of the statistical approach presented in the previous chapter show the variety of internationalisation profiles among the French regions. To report on regional internationalisation strategies, this second chapter focuses on the Regional Plans for Economic Development, Innovation and Internationalisation (SRDEII) produced between the end of 2016 and early 2017, which are strategic reference frameworks for the regions in terms of internationalisation.

The SRDEII respond to both the national and local challenges facing the regions. The assessments carried out during their development help guide the regions' action. The problems raised by the COVID-19 crisis include dependence on imports for components or essential resources to meet the needs of individuals and public or private organisations; securing supplies for strategic sectors, including through appropriate and diversified stock policies; the absence of co-ordination between ecosystem stakeholders at the international level; and the lack of clarity on national and European aid available to economic actors. The responses to these problems will be strengthened in the next generation of SRDEII (preparation of which is currently under way) and in specific contracts and other strategic reference documents, such as recovery plans.

The comparative analysis of SRDEII focus areas and projects related to internationalisation is, therefore, not just a means of verifying the relevance of the proposed methodology; it also makes it possible to provide an "inventory" of internationalisation policies for making decisions about programme development.

Lastly, our focus on the SRDEll does not mean that territorial internationalisation policies fall under the purview of the regions alone. Other national stakeholders (as well as sub-regional stakeholders such as metropolitan areas or other intercommunal bodies) have prerogatives and resources, which call for effective multilevel governance. ${ }^{17}$

To illustrate the relationships between the actors involved in regional internationalisation policies, this chapter includes a preliminary exploration of the mechanisms for co-ordinating between levels of government in key areas, such as export, investment attractiveness and infrastructure.

\footnotetext{
${ }^{17}$ The OECD and its Regional Development Policy Committee have developed this approach extensively to highlight the needs and good practices for co-ordination on a wide variety of policies that affect regional development - for a summary see Charbit (2020) and Allain-Dupré (2020).
} 


\subsection{The SRDEII: The first expression of the regions' jurisdiction over internationalisation}

In France, as in most other OECD member countries, responsibility for economic development - including, in particular, policies related to business, transport, communications and energy (OECD, 2019b) - is largely the domain of the regions: on average, economic development represents $27 \%$ of the regions' spending (OECD, 2020d). The Law of 7 August 2015 on the New Territorial Organisation of the Republic (known as the NOTRe law) has strengthened the regions' jurisdiction over economic development, notably by extending it to cover business support schemes, in particular within the framework of support for business internationalisation and innovation (French Republic, 2020; Régions de France 2020b).

Thus, economic development accounted for $32 \%$ of regional spending in 2016 , one of the highest rates among OECD member countries (along with Poland and Norway) as shown in Figure 2.1. The French regions show strong similarities to the Norwegian regions, devoting the core of their spending to two main areas: education/training and economic development.

Figure 2.1. Distribution of regional spending according to the classification of the functions of government (COFOG) (2016)

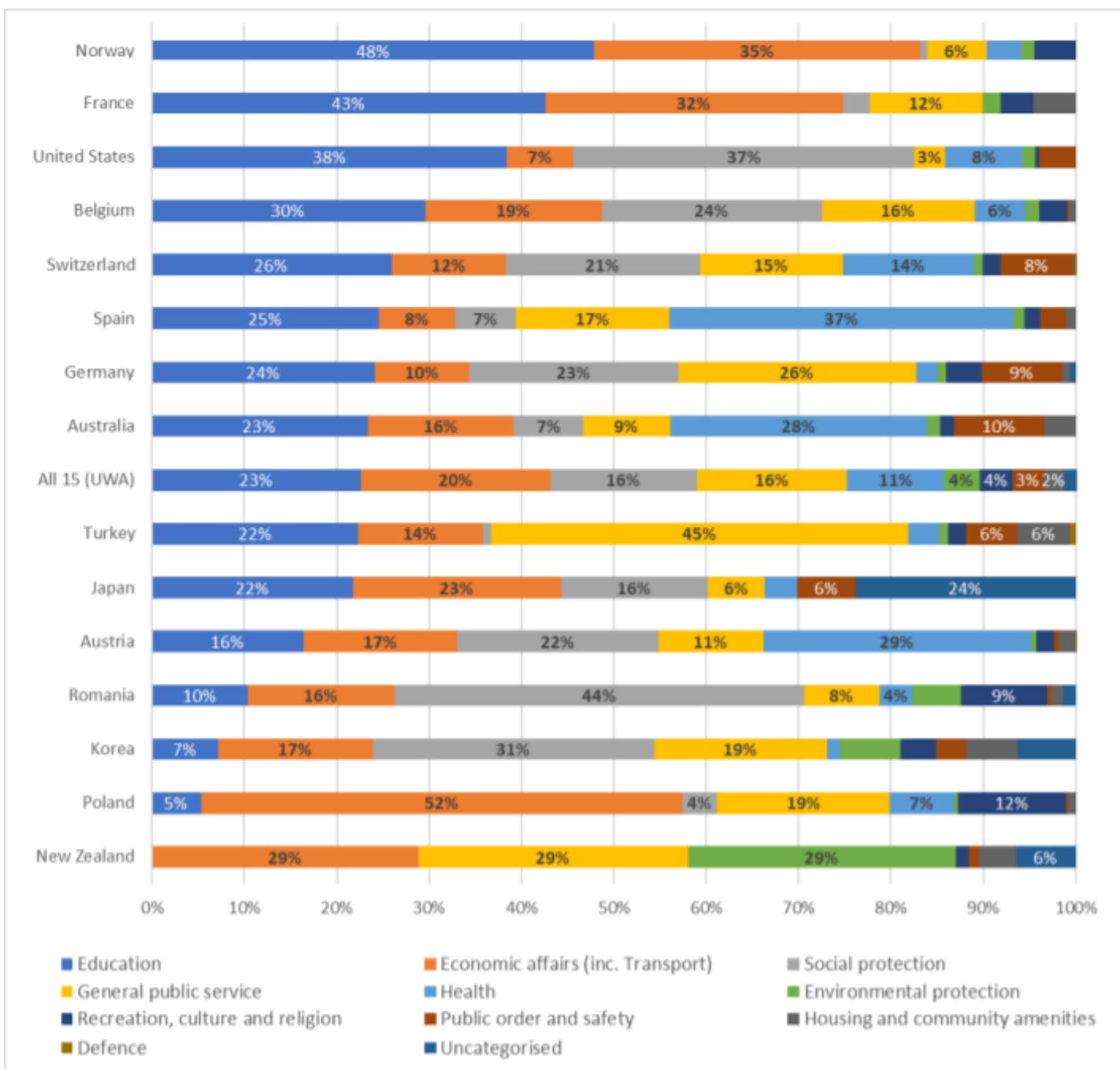

Source: Regional Government Finance and Investment Database, OECD 
In this context, the NOTRe law required the regions (which had been enlarged by merging) to produce a SRDEII for the 2017-21 period, presenting their internationalisation strategy for the first time. ${ }^{18}$ These strategic plans set out the regions' five-year road map for business support - including support for internationalisation, real estate investments and innovation - and regional attractiveness (article L 425113). They are the first strategic documents dedicated to the international dimension of regional action, particularly with regard to businesses, and they include a section dedicated to the social and solidarity economy.

A SRDEII is a prescriptive plan, which means that it governs the action of other local authorities in terms of economic development, and that it provides a framework for their interventions with businesses. A SRDEII reflects a region's strategic direction. It is not intended to propose strategies for all areas of public policy. Other areas are addressed by other strategic documents, such as the Regional Plan for Spatial Planning, Sustainable Development and Equality and the Regional Strategy for Higher Education, Research and Innovation. ${ }^{19}$

In addition to support for business internationalisation and support for territorial attractiveness, which are among the compulsory areas, ${ }^{20}$ the SRDEII also include optional areas for certain regions whose interpretation of internationalisation is broader, notably tourism and cross-border issues, which can be developed in consultation with the territorial authorities of neighbouring States. ${ }^{21}$

Lastly, the SRDEII constitute a governance exercise: article 4251-14 of the General Local Authorities Code provides that the preparation of the SRDEII-, which is therefore a prescriptive document, must involve consultation, in particular with metropolitan areas and public establishments for intercommunal cooperation (EPCl), as well as debates within the Territorial Conference on Public Action. The regions have often extended this participatory democratic process beyond the legal entities provided for by law, inviting private economic actors, representatives of civil society, universities, etc. to participate (see Section 3.2).

\subsubsection{OECD methodology for SRDEII analysis}

This section details how we analysed the content of the SRDEIl using a taxonomy of internationalisation policy and governance measures proposed by the OECD and linked to the dimensions set out in the previous chapter.

This qualitative analysis of the SRDEII complements the statistical analysis provided in the first chapter. First, the taxonomy takes up the four families of international connections identified in the database on the internationalisation of regions, i.e. infrastructure connections, human connections, knowledge connections and business connections. From this starting point, we aim to understand the variety of actions and focus areas contained in the territories' internationalisation policies as set out in the SRDEII of all 17 French regions, ${ }^{22}$ mainland and overseas. This will also enable us to identify the principal measures (whether transport policies, support for small and medium-sized enterprises (SMEs) and very-small enterprises (VSEs), measures to attract international students or research workers, etc.).

\footnotetext{
${ }^{18}$ 2019-21 in the case of French Guiana; "Territorial" plan for economic development, innovation and internationalisation in the case of Martinique. To our knowledge, a SRDEII has not yet been adopted in Mayotte.

${ }^{19}$ Also, the Regional Coherence Strategy for Digital Development to support the digital transformation of the territory and its stakeholders; and the Regional Planning Contracts for the Development of Vocational Training and Guidance (CPRDFOP). The SRDEII often echo the Regional Plans for Business Internationalisation (PRIE) and the Regional Plans for Innovation and Internationalisation (SRII).

20 The other compulsory areas are business support (creation, extension, difficulty); support for company investments in real estate; support for business innovation; support for the development of the social and solidarity economy; and measures to promote equality between men and women at work.

${ }^{21}$ Other optional areas include support for agricultural, artisanal, industrial, pastoral or forestry activities.

22 To our knowledge, a SRDEII has not yet been adopted in Mayotte.
} 
The taxonomy proposed for this policy analysis adds two dimensions to these four families:

- multi-objective internationalisation policies

- governance of internationalisation.

The specific analysis of multi-objective internationalisation policies makes it possible to identify the synergies between various dimensions of the SRDEII that have already been initiated by the regions (for example between tourism and environmental concerns, between investment and attracting talent). These analyses draw out the integrated strategic vision of the regions, whose approach to internationalisation very often goes beyond business support schemes (which are already difficult to target and implement).

The specific analysis of the governance of internationalisation allows us to take into account the institutional measures supporting co-ordination between the levels of government (national and sub-national), as well as with private sector and civil society representatives, without which these internationalisation policies would be difficult to implement at the sub-regional level. It is also a question of understanding how the regional teams plan to pilot, monitor and implement the international dimension of the SRDEII. It is important to analyse them because this first generation was implemented following the merger of the regions: the development of the SRDEII led to the first major territorial administrative transformations with regard to internationalisation (merger or creation of economic development and attractiveness agencies, for example). ${ }^{23}$

Finally, and pragmatically, considering governance enables all the international levers the regions plan to implement for their territories to be properly taken into account. While the regions devote a specific component of the SRDEII to internationalisation, on a larger or smaller scale, many do recognise the crosscutting nature of this objective, which appears in various components of their strategic document. Thus, internationalisation might be covered as a separate component, as in the case of the Grand Est region, which devotes one of its six "challenges" to "opening up internationally" but which has also developed an (optional) component on the cross-border dimension. Internationalisation might also be adopted in a more diffuse manner, as in Reunion, which mobilises the theme of internationalisation in four of its ten action plans, three of which concern attractiveness (SRDEII, Reunion region). To facilitate reporting of the contents of the SRDEII, these were analysed and divided into groups of items, each describing the different kinds of connection. While the connections are the same, the descriptors differ from those used for the quantitative analysis, for which the first framework presented in this work was established in advance based on the analysis of relevant data and available indicators. The two additional dimensions (governance and multi-objective policies) were added.

These items therefore make it possible to report on all the themes used by the regions to describe the strategies they have deployed within the framework of the first generation of SRDEII (see Table 2.1).

${ }^{23}$ The Régions de France (2018) association highlighted many of these reforms in a study on the economic role of the regions. 
Table 2.1. Taxonomy of regional internationalisation policies and their governance

\begin{tabular}{|c|c|}
\hline \multirow[t]{3}{*}{ Human connections } & Identification of shortage occupations (public/private sector) \\
\hline & Specific measures for visitors/tourists \\
\hline & Specific measures for businesses in the tourism sector \\
\hline \multirow[t]{5}{*}{ Business connections } & Identification of priority sectors - foreign direct investment (FDI) \\
\hline & Identification of priority sectors - exports \\
\hline & Specific measures for SMEs and VSEs \\
\hline & Vocational training measures targeted towards internationalisation \\
\hline & Specific measures to create economic activity zones, free-trade zones, etc. \\
\hline \multirow[t]{4}{*}{ Knowledge connections } & Specific measures for foreign students \\
\hline & Specific measures for foreign research workers \\
\hline & Specific measures for research and development \\
\hline & Specific measures for international cultural connections (school exchanges, etc.) \\
\hline \multirow{2}{*}{ Infrastructure connections } & Specific measures for international transport \\
\hline & Specific measures for digital infrastructure \\
\hline \multirow[t]{8}{*}{ Multi-objective internationalisation policies } & Territorial marketing \\
\hline & Identification of priority partner countries/regions \\
\hline & Linkage with national programmes for economic development (programme) \\
\hline & Linkage with European funding programmes (programme) \\
\hline & Integrated vision of internationalisation "targets" (investors, talent, visitors) \\
\hline & Local employment targets (number and level) \\
\hline & $\begin{array}{r}\text { Linkage with the } 2030 \text { Agenda and its } 17 \text { Sustainable Development Goals (objectives for } \\
\text { sustainable development, particularly through the conservation of resources, certain territories } \\
\text { or species, diversification of energy resources, etc.) }\end{array}$ \\
\hline & Regeneration of specific territories (urban, peri-urban, predominantly rural territories, etc.) \\
\hline \multirow[t]{10}{*}{ Governance of internationalisation } & Ex-ante consultation mechanism (stakeholders) \\
\hline & Ex-post consultation mechanism (stakeholders) \\
\hline & Institution(s) responsible for implementing the strategy (agency, department of the region, etc.) \\
\hline & Outcome and/or impact evaluation \\
\hline & Intra-regional co-operation with other territorial authorities or agencies \\
\hline & Region/State co-ordination mechanism(s) \\
\hline & Region/European Union co-ordination mechanism(s) \\
\hline & Inter-regional co-ordination mechanism(s) \\
\hline & Cross-border co-ordination mechanism(s) \\
\hline & Specific regional attractiveness governance mechanism (stakeholders) \\
\hline
\end{tabular}

Source: The authors, based on the SRDEll of the 17 regions.

The measures in Table 2.1 above, classified according to the four families of international connections, are encapsulated and cited in different ways in the SRDEII. Textual analysis of the SRDEll shows that the different dimensions of internationalisation (proposed in the original methodology for assessing regional globalisation and embodied by the four families of connections, see Chapter 1) cover all the internationalisation measures. The means of implementation added here (multi-objective policies and multi-actor governance) clearly complement these dimensions given the number of times the regions refer to them in their strategies. They also make it possible to reflect the variety of regional internationalisation practices.

\subsubsection{The internationalisation strategies of the French regions}

After some general observations, this analysis presents the internationalisation strategies adopted by the French regions according to the four families of connections. To do this, we mobilise both statistical and 
qualitative information. We conclude by focusing on some of the findings of the analysis and their relevance given the context of the COVID-19 crisis.

Although the various dimensions of regional internationalisation proposed in this taxonomy are present in the SRDEII, confirming their relevance as part of an underlying framework, the internationalisation strategies adopted by the regions are first and foremost oriented towards businesses. Business connections are indeed better "handled" 24 in the SRDEII than the other families of connections. This is not surprising, given the role of the regions in supporting businesses in their export activities or the establishment of foreign companies in the territory (Banque des territoires, 2017). ${ }^{25}$

Conversely, the theme of internationalisation through knowledge connections, in particular policies to attract talent (especially foreign research workers and students), is relatively less well addressed in the SRDEIl because it is covered by a dedicated policy document: the Regional Strategy for Higher Education, Research and Innovation.

In addition to the specific measures presented in the following section, this taxonomy also takes into account the presence of a multi-objective vision of the internationalisation of attractiveness policies in the SRDEIl, which acknowledges the link between training and attracting talent on the one hand, and welcoming foreign investors on the other. ${ }^{26}$

It also makes it possible to document the innovations proposed by the regions with regard to multi-level governance, notably to include sub-national (EPCI in particular), national and economic actors, as well as European and cross-border partners in defining and implementing internationalisation policies (see Section 2.2.1).

We now set out the internationalisation measures proposed by the regions in the following four sections, each devoted to a family of international connections. Each section is introduced by a statistical table using the indicators presented in the first chapter, which position the French regions in relation to other French regions and to the median of OECD regions. This approach makes it possible to see whether the internationalisation policies adopted by the regions are in line with the strengths and difficulties identified by the statistical comparison.

\footnotetext{
${ }^{24} 62$ measures were identified and 11 were addressed more broadly in the SRDEll of the 17 regions.

25 The prescriptive nature of the SRDEII means that regions are obliged to provide financial support to companies (according to the priorities for export support or attractiveness identified in the plan).

${ }^{26}$ Examples include the "innovation-export" link promoted by Brittany, the link between tourism and the establishment of foreign companies in the Nouvelle-Aquitaine region, the link between research and internationalisation by attracting talent in the area of infrastructure in the Hauts de France region.
} 
(i) Infrastructure connections

Figure 2.2. Positioning of the French regions according to the internationalisation indicators: infrastructure connections

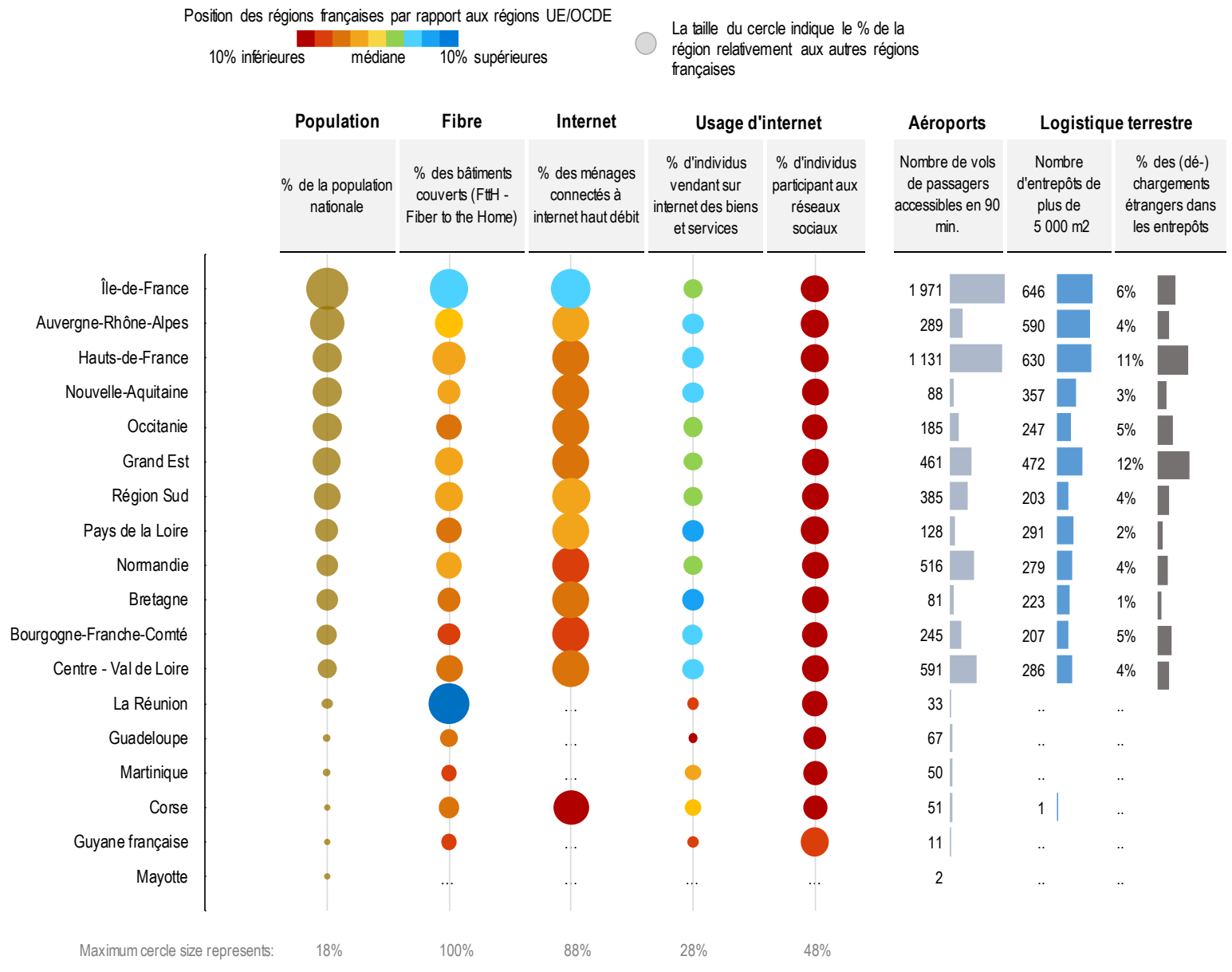

Note: The regions are listed in descending order by population. In this figure, the colour of the circles identifies the position of the French regions compared with the $\mathrm{OECD}$ regions, except for Internet use (which is compared with European regions).

Source: OECD database on the internationalisation of the French regions; France's Electronic Communications, Postal and Print media distribution Regulatory Authority (ARCEP) data (fibre); Eurostat (Internet and Internet usage); the European Commission (access to airports); and the National Agency for Territorial Cohesion (ANCT) (land-based logistics).

The indicators on infrastructure connections (Figure 2.2) provide a range of information about French regions:

- The fibre roll out in France remained uneven at the end of 2019. All homes on Reunion are connected to fibre, as are nearly $90 \%$ of homes in the Île-de-France region, while in the third region (Hauts-de-France) only slightly more than $60 \%$ of homes had fibre coverage. This gap is probably due to a late roll out when we compare this indicator with other OECD countries (data circa 2016), where most French regions were below the OECD median. We also see the same lag compared with the best performing foreign regions in terms of the share of households connected to broadband in 2019; however, the French regions are more homogenous in this respect.

- The French regions seem to be lagging less so when it comes to Internet usage. More than $27 \%$ of the inhabitants of the Pays de la Loire region and Brittany use the Internet to buy and sell goods and services. These regions are among the $20 \%$ of European regions where this type of use is 
most developed. On the other hand, very few French people were using the Internet to participate in social networks in 2019.

- Île-de-France and Hauts-de-France are the main hubs for passenger air transport and for large warehouses; there is no comparative data from OECD regions for these indicators, so only a national comparison between regions is possible. With more than $11 \%$ of their loading (and unloading) to (and from) abroad, Grand Est and Hauts-de-France are the leading French regions in this respect, while foreign unloading in Île-de-France, the third region, is much lower, standing at only $6 \%{ }^{27}$

The internationalisation indicators therefore make it possible to chart regional disparities in access to and use of infrastructure.

Nevertheless, all the regions consider infrastructure as a major lever for internationalisation that they plan to mobilise for the benefit of their territories and businesses. Even though the issue of infrastructure and key equipment is covered in other programmatic and operational documents, ${ }^{28}$ the international connectivity of the regions is mentioned in 14 of the 17 SRDEII, and all the regions stress the importance of digital infrastructure to promote the international development of their territories.

The regions propose focusing on international transport - port, airport, land - to encourage the integration of businesses into global value chains. The measures envisaged include, for example, the expansion or construction of airports (Pays de la Loire and Auvergne Rhône-Alpes regions), the consolidation or creation of international shipping routes and port facilities (Corsica, Réunion, Pays de la Loire, Guadeloupe and Brittany). For some regions, logistics and transport are priorities for territorial development: the Sud region, for example, considers transport as one of the three major focuses of its SRDEII, because "the connectivity of the region with the whole world will be one of the main challenges for regional economic and tourism development and a strong factor in attractiveness."

Some regions emphasise the importance of infrastructure, including digital infrastructure, as a factor in attracting foreign visitors: the Hauts de France region, for example, is targeting multi-use infrastructure (waterways and freight) for logistics and tourism as well as scientific research purposes. Normandy plans to develop "holiday Internet" for its visitors, while Martinique plans to support new air links to mainland France, the Caribbean and the Americas.

Infrastructure must also allow the inclusion of regions in cross-border areas. Cross-border routes (Sud region, Grand-Est, Bourgogne Franche-Comté), port linkages (cross-Channel, in the case of Normandy, Sud and Hauts-de-France regions) and river linkages (the Sud and Auvergne-Rhône-Alpes regions) are therefore useful, both for integrating regions into global value chains and for increasing the movement of workers and visitors (see also the section on human connections). For non-border regions, the infrastructure concerned must also be part of an inter-regional approach - as in the case of the Seine Valley or the Seine-North Europe Canal, for example - to connect territories internationally, in co-operation with neighbouring regions.

The regions are also investing in digital infrastructure, which they consider to be a necessary channel for integrating regional companies into the global economy. Thus, the Centre-Val de Loire region recognises companies' "different needs, according to their size, sector of activity or degree of maturity" to remain competitive in international markets, whereas for Martinique, support for digitalisation - via targeted funds - should make it possible to "facilitate the digital transformation of companies, thus opening the door to better managerial and commercial organisation and, in the long term, better international positioning."

\footnotetext{
${ }^{27}$ International comparison is not available at this stage for this indicator.

${ }^{28}$ In particular the Regional Plan for Spatial Planning, Sustainable Development and Equality (SRADDET) and the Digital Territorial Development Master Plan.
} 
For many regions, strengthening infrastructure is a prerequisite for the development of new international opportunities, whether to support exports or attract foreign investment. The Occitanie region is therefore seeking to promote its expertise in port logistics and port/freight/river/road intermodality at international trade fairs. The Pays de la Loire region has stated that, for example, that the Smart Ideas to Link Energies (SMILE) smart grid project, run in co-ordination with Brittany since 2016, "is intended to be a French industrial showcase by 2020 , which can be exported to other regions and abroad." In terms of digital infrastructure, Île-de-France is keen to develop a culture of services and digital transformation to attract investors, while the Hauts-de-France region sees the digital sector as made for economic specialisation, for example, in big data or cyber-security. Moreover, the digital aspect is frequently at the heart of regional challenges around human connections.

(ii) Human connections

Figure 2.3. Position of the French regions based on the internationalisation indicators: human connections

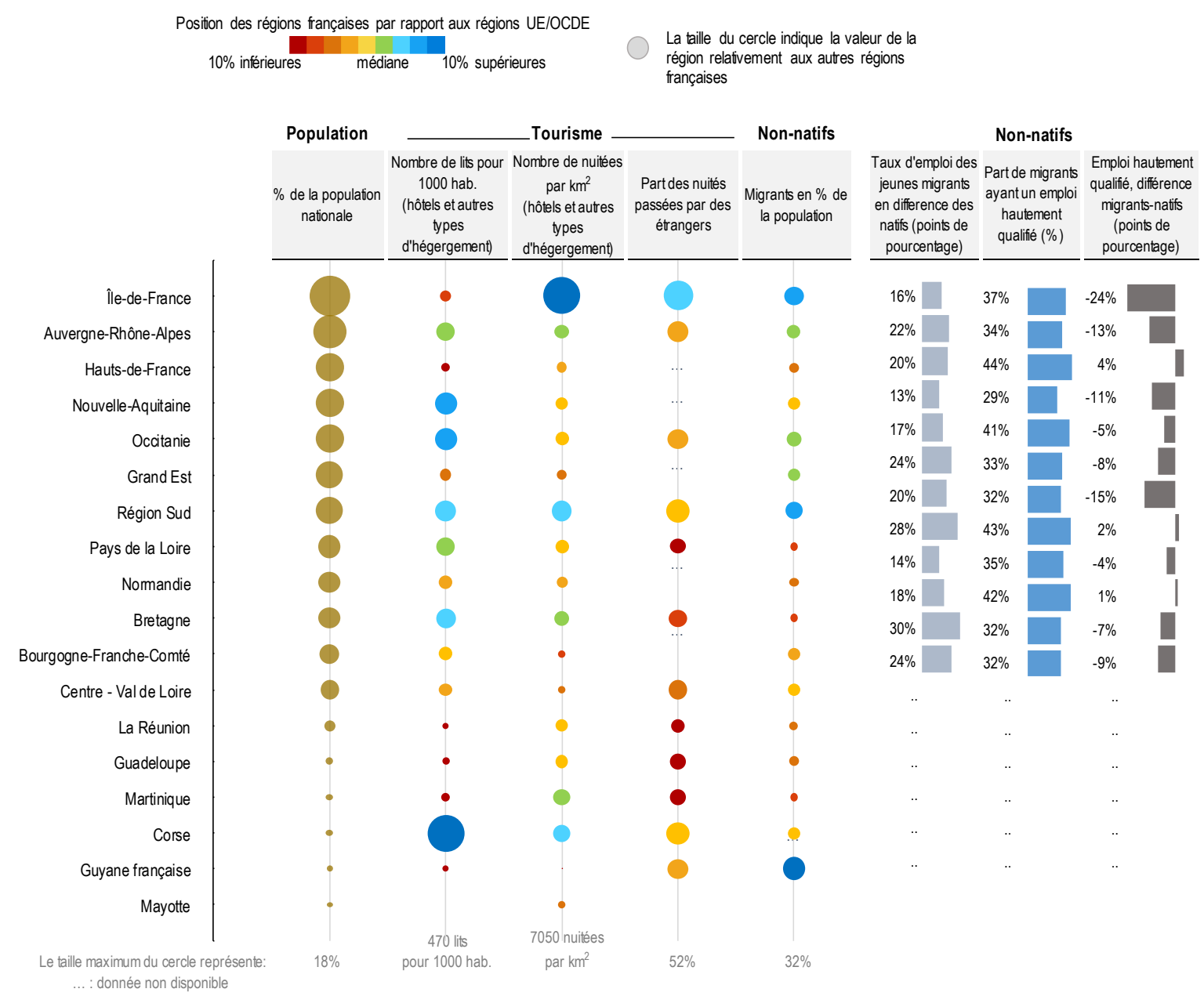

Note: The regions are listed in descending order by population.

Source: OECD database on the internationalisation of the French regions and Eurostat (tourism). 
The human connection indicators (see Figure 2.3) provide a range of information about the French regions:

- Hotel infrastructure is particularly well developed in Corsica relative to its population: the region has a tourist accommodation capacity of 470 beds per 1000 inhabitants, i.e. more than three times the capacity of Nouvelle-Aquitaine and Occitanie. This places Corsica in the top $10 \%$ of European regions for this metric. Île-de-France, which has a much higher population density, has the highest number of overnight stays per $\mathrm{km}^{2}$ of the French regions, demonstrating less seasonality than other tourist regions. Île-de-France is the only French region in the $20 \%$ of European regions that host a high proportion of foreign tourists, accounting for more than half of all overnight stays.

- More than $30 \%$ of the population of French Guiana is foreign-born, 10 percentage points higher than Île-de-France and the Sud region. Young immigrants are relatively well integrated in the Bourgogne-Franche-Comté and Pays de la Loire regions, where their employment rate is 28 percentage points higher than that of the native-born population. Hauts-de-France, Pays de la Loire and Brittany attract the most qualified immigrants, while there is a significant gap in worker qualification levels between the immigrant and native-born population in Île-de-France and the Sud region.

Our review of the SRDEIl confirms the importance of tourism and measures to meet the labour needs, including for foreign labour, ${ }^{29}$ of businesses in the territories.

In the context of the megatrend towards digitalisation, the regions are affected by the availability of the expertise required to help businesses digitalise. It is important to both train and attract talent, as the absence of talent may not only harm local companies' international development but also hinder them in attracting foreign investors. Often, the shortage occupations discussed in the SRDEII are not specifically considered from an international perspective - as in the case of fishing, agriculture or civil engineering (Martinique, French Guiana, Occitanie and Nouvelle-Aquitaine). The majority of the SRDEII highlight significant demand for specialised labour in the digital sector - coders, developers, etc. (Corsica, Guadeloupe, Brittany, Pays de la Loire, Auvergne-Rhône-Alpes and Centre-Val de Loire). For example, the Auvergne-Rhône-Alpes region highlights that it has 1900 unfilled job vacancies in digital companies.

In addition, some regions note that it is difficult to recruit staff to the tourism industry in certain territories (Nouvelle-Aquitaine and Normandy). Normandy emphasises that "the recruitment and retention of a trained and qualified workforce is the main difficulty for growing companies in Normandy today. Training is a problem, as is attractiveness, both of the professions and of the companies and territories where they are located." 30

More broadly, although measures linked to tourists and tourism businesses are included in the Regional Scheme for the Development of Leisure and Tourism (SRDT), ${ }^{31}$ the SRDEll often address this area: proposing general approaches to welcoming foreign visitors, and above all, proposing mechanisms to support tourism businesses (11 of the 17 regions propose specific measures and 4 others address this topic).

The regions' tourism ambitions, as expressed in their SRDEII, reflect either the desire to consolidate an already favourable market position (Corsica, Auvergne-Rhône-Alpes and Occitanie), to respond to the stagnation - or even the downturn - of tourism (Guadeloupe ${ }^{32}$ ), or, for regions that are traditionally less touristic, to become a new player on the market (French Guiana and Hauts-de-France). ${ }^{33}$ In general, the

\footnotetext{
${ }^{29}$ Attracting foreign research workers and international students is discussed in the knowledge connections section).

${ }^{30}$ SRDEII, Normandy.

31 The Île-de-France, Sud and Bourgogne-Franche-Comté regions, which do not specifically address this subject, expressly refer to their SRDT. The Grand-Est region states that the SRDT could, therefore, constitute the tourism component of the SRDEII.

${ }^{32}$ Thus, Guadeloupe's SRDEII, diversifying the tourist offer, improving quality and developing cruise tourism has enabled the sector to recover following the 2008-09 crisis.

${ }^{33}$ French Guiana aims to position itself in this sector by promoting cultural and sporting events.
} 
measures proposed involve increasing the range of tourist activities by developing "sectors of excellence" and quality label policies (Occitanie, Martinique ${ }^{34}$ and Guadeloupe), innovating in tourism, such as by digitalising and analysing tourist routes in-depth (Corsica, Auvergne-Rhône-Alpes and Occitanie), and diversifying the experiences on offer (river tourism for Hauts-de-France and "alternative routes" in conjunction with the National Forestry Office for Guadeloupe).

To achieve their ambitions, the regions propose various financial, administrative and engineering options to promote staff training (particularly in connection with the Regional Planning Contracts for the Development of Vocational Training and Guidance (CPRDFOP); preserve land and real estate, support marketing and commercialisation, and support the digitalisation of the sector (Auvergne-Rhône-Alpes, Corsica and Occitanie). Innovation in tourism, in particular, involves establishing specific information exchange and analysis mechanisms (Tourism Living Lab in Corsica), as well as supporting the creation of specific skilled jobs (10 000 positions are expected in digital tourism in the Auvergne-Rhône-Alpes region). As with infrastructure connections, human connections - whether they are related to shortage occupations or to measures to promote the tourism industry - demonstrate the importance of innovation, digitalisation, and, consequently, improved integration of the regions into the knowledge economy.

(iii) Knowledge connections

Figure 2.4. Position of the French regions based on the internationalisation indicators: knowledge connections

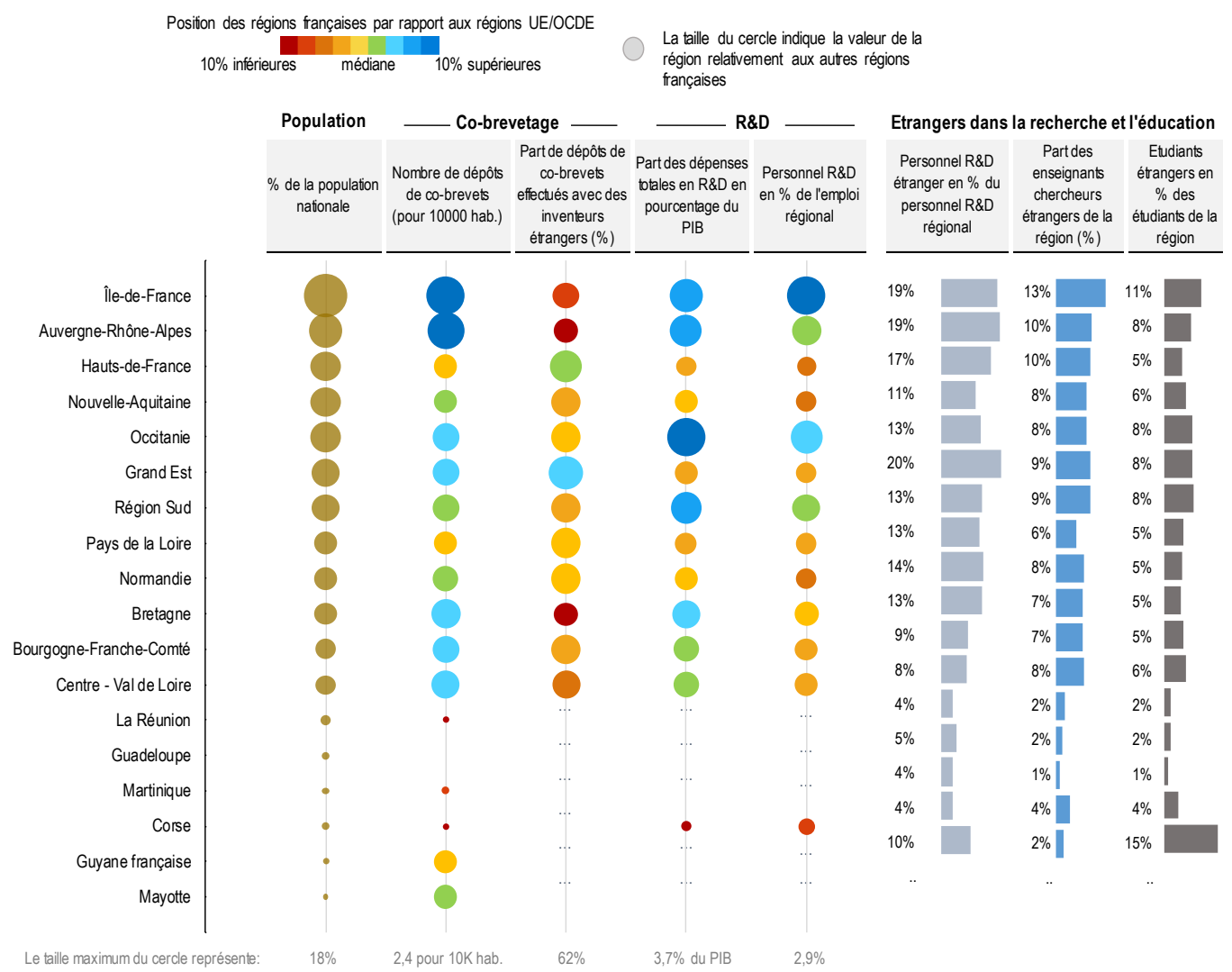

Note: The regions are listed in descending order by population. In this figure, the colour of the circles identifies the position of the French regions compared with the OECD regions.

Source: OECD database on the internationalisation of the French regions, Eurostat (R\&D expenditure and personnel), the ANCT Territorial Observatory (foreign teacher-research workers and international students).

\footnotetext{
${ }^{34}$ Martinique aims to develop the sectors of natural well-being, flavour-gastronomy-spiritual tourism, business, culture and sport, boating and cruises.
} 
Knowledge connection indicators (Figure 2.4) provide a range of information about the French regions:

- The île-de-France and Auvergne-Rhône-Alpes regions are trailblazers among the French regions in terms of patents filed by co-inventors, with more than 2 patents per 10000 inhabitants. Seven French regions are among the top 30\% of OECD regions for filing this type of patent. That said, only the Grand-Est region is in the top 30\% of OECD regions for co-patenting with one or more inventor(s) located in a foreign region.

- In Occitanie, expenditure on research and development (R\&D) represents $3.7 \%$ of GDP. Moreover, only four French regions are above the median of European regions (1.6\%) with the highest allocation of personnel to R\&D.

- Nearly $20 \%$ of the R\&D personnel employed in the Grand-Est, Île-de-France and AuvergneRhône-Alpes regions are foreign-born. Île-de-France remains the region with the highest concentration of foreign teacher-research workers (13.5\%) and international students (10.5\%).

In terms of public policy, the regions consider innovation to enhance territorial economic development. While some look at innovation through the narrower prism of the "domestic" market, the vast majority - whether they are among the most innovative regions or not (see Figure 2.6) - include measures to promote R\&D, with the aim of opening up their territories to European or even international collaboration and benefiting from innovation to support their companies' international activities. To a lesser extent, the regions also aim to attract foreign research workers and international students to their territory.

European knowledge connections are at the heart of regional internationalisation. The SRDEII are based on the work carried out by the regions while developing their Smart Specialisation Strategies (S3). ${ }^{35}$ Therefore, the strategies for internationalising regions through knowledge connections fit within the framework of the research programmes initiated by the European Union. Consequently, implementing these strategies involves coordinating with the national and supranational levels, with Horizon 2020, in particular, mentioned by a large number of regions (see also Section 2.2 on governance measures). The most active regions in terms of "internationalised" research (Île-de-France, Occitanie and Grand-Est) are also the most ambitious in terms of international R\&D co-operation. Some regions plan to continue implementing cross-border projects (Minnovarc and Innovarc for Bourgogne-Franche-Comté, in partnership with Switzerland). Others encourage creating new European research dynamics: for example, the Hauts-de-France region's Welcome EU project, which aims to host European researchers and projects in specific sectors (cybersecurity, fintech, etc.); or the Grand-Est region's plans to propose cross-border $R \& D$ projects in the industrial, agricultural, wine and forestry sectors. Still other regions plan to develop global hubs or to strengthen co-operation between competitiveness hubs and clusters at the global level (Occitanie, Île-de-France and Nouvelle-Aquitaine). Lastly, regions that are less active in R\&D, such as Corsica and Guadeloupe, also have ambitions to participate in European and international research.

The regions also see innovation as a relevant factor for attracting foreign companies. Thus, the Pays de la Loire region asserts that establishing a technological research institute will be beneficial to SMEs as well as large groups. Similarly, companies are encouraged to innovate to become more competitive internationally (Occitanie, Île-de-France, Pays de la Loire and French Guiana). For Occitanie, the business leaders of the "industry of the future" must participate alongside regional institutes in collaborative projects with international research teams; while for French Guiana, the internationalisation potential of its companies lies in their non-price competitiveness, supported by a regional innovation network.

The regions are also very aware of the importance of talent for the economic development of their territories, as well as the increased international competition for such talent. As mentioned in

\footnotetext{
${ }^{35}$ As part of the 2014-20 programming of European funds, the European Union asked all European regions to develop a "smart specialisation strategy" for research and innovation in their territory (CGET, 2015).
} 
Nouvelle-Aquitaine's SRDEII, regions must consider the different dimensions of territorial attractiveness, which requires "mobilising and attracting talent through assets related to quality of life, working conditions, management methods and work-life balance" (Nouvelle-Aquitaine region, 2017). Some SRDEII provide for measures to strengthen territorial attractiveness to talent, ${ }^{36}$ such as creating "international" campuses (Auvergne-Rhône-Alpes and Grand-Est). The overseas regions, which receive many international students, are particularly attentive to this issue. Guadeloupe, for example, plans to take advantage of its privileged location to "promote exchanges with research workers from neighbouring Caribbean countries, and establish research programmes and joint projects with neighbouring countries." Reunion aims to attract international students by removing certain obstacles (i.e. by facilitating scholarships, accommodation, ${ }^{37}$ visas, etc.). Other regions also plan to capitalise on talent flows (former research workers or international students - Brittany, Corsica and Pays de la Loire) to develop new networks and alliances. However, in contrast to tourism (see Human connections section), on the whole, few regions use their SRDEII to propose measures for foreign research workers and students - these are instead included in their Regional Strategy for Higher Education, Research and Innovation. ${ }^{38}$

The SRDEII therefore draw heavily on the regional S3, which they propose to extend and consolidate. However, the innovative sectors in the S3 are also frequently mentioned in relation to promoting exports and territorial attractiveness (as already seen in the digital field). The SRDEII also apply the S3 to "use innovation to serve companies and exports" and territorial attractiveness, as explained in Guyana's SRDEII.

\footnotetext{
${ }^{36}$ The OECD analysis corroborates the results of a survey by the Territorial Observatory for the International Mobility of Students and Researchers (Campus France, 2018), according to which 10 regions included student-researchers' international mobility in their SRDEII (11 according to the OECD taxonomy).

${ }^{37}$ île-de-France also prioritises facilitating access to accommodation for foreign research workers and students.

${ }^{38}$ Five regions mention specific measures for international students, and six regions include measures for foreign research workers.
} 
(iv) Business connections

Figure 2.5. Position of the French regions based on the internationalisation indicators: business connections

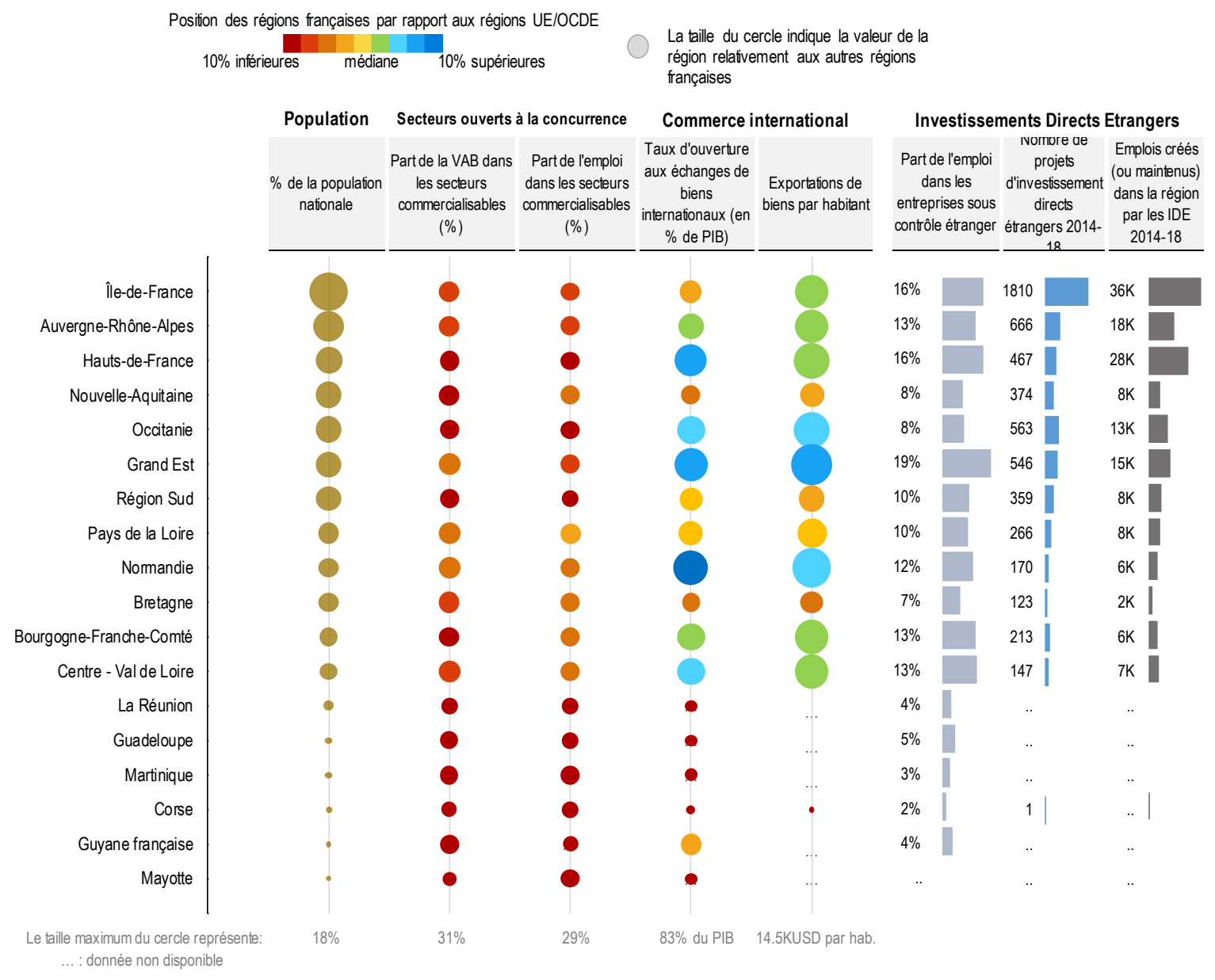

Note: The regions are listed in descending order by population. In this figure, the colour of the circles identifies the position of the French regions compared with the OECD regions.

Source: OECD database on the internationalisation of the French regions; French Customs (international trade); Territorial Observatory, ANCT (foreign groups); Business France (FDI).

Business connection indicators (Figure 2.5) provide a range of information about the French regions:

- The tradable goods sectors account for less employment and wealth creation in the French regions than they do in other OECD countries at the regional level. As a national average, tradable sectors accounted for $28 \%$ of France's gross value added in 2016, the lowest value among OECD countries, after Portugal and Norway. For the share of employment in tradable sectors, France ranks sixth lowest, between the United States and Australia, with 25\%.

- Openness to international trade in goods, measured by the sum of imports and exports over regional GDP, is relatively high in Normandy, Grand-Est and Hauts-de-France.

- Nearly $20 \%$ of companies in the Grand-Est region and $16 \%$ in the Île-de-France and Hauts-deFrance regions are foreign-owned. FDI is concentrated in Île-de-France, with 1810 projects carried out over the 2014-18 period and 36000 jobs created or maintained. 
Above all, the SRDEll set out a regional policy framework for businesses, especially through policies to promote exports and attractiveness. This is clearly illustrated in the preamble of the Pays de la Loire region's SRDEII:

"Our action must be rooted in this obvious fact, which has too often been forgotten: businesses, not the authorities, create jobs. Returning to this fact is a reminder that our role is not to pile up measures or projects without viable economic models, but to create the conditions for freedom and, above all, for businesses to be competitive through simplification, innovation, internationalisation and training."

The objectives benefitting businesses contained in the SRDEll are wide ranging, both in terms of exports (specific measures for SMEs and VSEs, identifying priority sectors) and attractiveness (priority sectors for foreign investment, specific measures to enhance economic activity zones and exports). ${ }^{39}$

The business internationalisation strategy is, above all, an export strategy for SMEs and VSEs. All the regions offer a wide variety of measures for small businesses in their SRDEII, despite already having Regional Plans for Business Internationalisation (PRIE). ${ }^{40}$ These include calls for projects to raise private funds (Martinique and Corsica); organisation into clusters and sectors (Martinique, French Guiana and Auvergne-Rhône-Alpes); financial support and fiscal experiments (Corsica); fiscal experiments (CentreVal de Loire, Reunion and Corsica); international information and economic intelligence services (Bourgogne-Franche-Comté, Pays de la Loire and Occitanie); support to scale up SMEs, in particular by acquiring intermediate-sized enterprise (ETI) status (Brittany and Grand-Est); support to participate in international trade fairs (Occitanie); implementation of peer-to-peer mentoring for first-time exporters and those already established abroad (Grand-Est).

Furthermore, 16 of the 17 SRDEll clearly set out sectoral priorities for exports, based on the S3. The sectors most frequently mentioned are digital, agro-food, health and the silver economy, energy, transport (including aeronautics) and tourism. Other export sectors are more specific: for example, mining activities (French Guiana) or naval activities (Brittany and Sud region).

In keeping with the concept of specialisation, the priority export sectors are generally those sectors in which the regions aim to attract foreign investors. Some regions consider that export businesses in their territory should also serve as "showcases" to attract potential foreign investors. For example, Corsica plans to establish "a VIE network ${ }^{41}$ with a view to promoting Corsican companies' exports and the economic image and attractiveness of the territory" (Corsica Territorial Authority, 2017). As with exports, the regions propose specific measures aimed at foreign investors. For example, two regions explicitly mention the synergies identified between exports and investments. The Grand-Est region, which is very receptive to foreign companies (Figure 2.7), plans to "capitalise" on the presence of these companies to attract business decision-making hubs and create cross-border activity areas, while recognising that its exports are overdependent on the activities of foreign subsidiaries. French Guiana, where "only" $4 \%$ of firms are foreign-owned, considers that developing the mining sector would involve operations that "only multinationals can (...) finance" and plans to adapt the legal framework for industrial mining. For these regions, but especially for the overseas regions in general, attracting foreign finance should enable them to reposition themselves in global value chains around activities with higher added value and that are more competitive on an international scale. ${ }^{42}$

\footnotetext{
39 These financial support measures complement the work of the inter-communal and communal authorities.

${ }^{40}$ The PRIE aim to strengthen regional action to identify and support companies to export. The PRIE establish goals and actions and organise territorial export support systems by connecting all the actors involved (particularly public banks, chambers of commerce and industry, and competitiveness hubs).

41 International volunteering in business (Volontariat International en Entreprise).

${ }^{42}$ This dimension is mainly mentioned by the overseas regions, as changes in international trade regulations are weakening their competitiveness.
} 
Attracting foreign investors is part of a spatial strategy. In most cases (10 of the 17 regions), ${ }^{43}$ the regions plan to implement financial, real estate and land measures to develop economic activity zones. However, most SRDEIl do not include a specific strategy for economic activity zones. The SRADDET ${ }^{44}$ address the land issue within the scope of territorial land use planning, responsibility for which is shared with central government. Furthermore, there is interest in developable land at several administrative levels, with a view to creating and managing activity zones and increasing regional attractiveness. This interest is framed by local urban planning documents (PLU/PLUi/Scot ${ }^{45}$ at the EPCI level) and by the SRADDET at the regional level, which governs the local documents. The SRADDET can, therefore, limit the development of this developable land, most often based on environmental considerations (biodiversity, combatting land take, etc.). Some regions, such as the Sud region or Reunion, have nevertheless identified ways to make economic activity zones more attractive through the lens of transport and connectivity; while Île-de-France plans to increase sectoral diversity in economic activity zones "based on the focus areas contained in the SRDEII" (Île-de-France Region, 2017).

Lastly, some regions plan to mobilise and develop expertise around internationalisation in their territory, ${ }^{46}$ above all to create jobs. ${ }^{47}$ The SRDEII also include a component on developing internationally oriented skills. Despite the use of Regional Planning Contracts for the Development of Vocational Training and Guidance (CPRDFOP), some regions nonetheless use the SRDEll as a reminder of their commitment to supporting vocational training for internationalisation purposes (Bourgogne-Franche-Comté, Normandy, Occitanie and Grand-Est). The Pays de la Loire region proposes to support professionals working internationally to master English, and to support European and international mobility programmes. The Grand-Est region aims to make professional trilingualism the norm (aiming for both "local" and more global internationalisation). Lastly, Occitanie offers specific services to train international business leaders, as well as support with building sales teams for companies that have adopted export plans with at least a twoyear time frame.

The traditional levers used by territories to attract foreign investors (tax benefits, flexibly applying standards, etc.) are the exception rather than the rule in the regions' internationalisation strategies. French Guiana mentions simplifying environmental standards to renew mining operations while respecting the principles of sustainable development and providing financial support to encourage foreign companies to employ local workers. ${ }^{48}$ Above all, regional action is focused on training and investment measures, infrastructure and services, and, lastly, governance. The most innovative approaches involve co-operation between public and private, national and sub-national, and regional and foreign actors. For example, most regions encourage local businesses to "hunt in packs" when seeking out potential business partners.

\section{Observations on the SRDEII in the context of the COVID-19 crisis}

From this overview of the SRDEII, we can conclude that the regions are taking ownership of their responsibility for international development, especially its economic dimension (concerning business connections). Several observations can be drawn from this analysis:

- The French regions do not refer to using traditional policies to attract foreign investors, which are focused on financial incentives, the effects of which are, moreover, disputed (Poulhès, 2018; OECD, 2015; OECD, 2016). ${ }^{49}$

\footnotetext{
${ }^{43}$ These are the regions that either receive the most FDI (Île-de-France, Auvergne-Rhône-Alpes and Grand-Est) or the least (Brittany) (as a share of national FDI, excluding the overseas regions).

${ }^{44}$ Twenty-year Regional Plan for Spatial Planning, Sustainable Development and Equality.

${ }^{45}$ Local Urban Plan, Local Inter-communal Urban Plan and Territorial Coherence Plan.

4612 of the 17 regions address or detail measures to promote vocational training in relation to internationalisation.

${ }^{47}$ Guadeloupe (2017), for example, considers that "integrating young people into the world of business and work will underpin all the areas developed in the plan."

${ }^{48}$ Territorial authorities of French Guiana (2019): "it is important to maintain the territory's attractiveness to foreign investors, particularly by providing legal security in respect of industrial mining."

${ }^{49}$ The OECD (2015) has identified 12 policy areas that influence investment flows. These include investment, investment promotion and facilitation, competition, trade, tax, corporate governance, financing investment, investment in infrastructure, developing human
} 
- They undertake attractiveness enhancing projects that focus on infrastructure, services and workforce skills - benefiting investors as well as local residents and businesses in keeping with the concept of regional well-being.

- The regional attractiveness strategies and the way they are communicated do not, however, highlight their relationship to regional well-being. As the regions seek a balance between economic development and respect for the environment and biodiversity, some are considering more concrete measures to harness their environmental amenities, predominantly to attract visitors and investors (especially in environmental innovation and R\&D) and less to attract new residents. As regards the environmental dimension, as well as other aspects of well-being, the French regions have many advantages over other OECD regions (see Box 2.1 and Figure 2.6).

resources for investment, policies for enabling responsible business conduct, investment framework for green growth, and public governance. The Recommendation of the Council on Effective Public Investment Across Levels of Government (OECD, 2014) supports public actors to implement investment policies aimed at regional development, allows approaches to be compared internationally and identifies good practice (this recommendation is updated regularly). 


\section{Box 2.1. Regional well-being}

The OECD's work on well-being is based on the September 2009 report by the Stiglitz-Sen-Fitoussi Commission on the Measurement of Economic Performance and Social Progress. In this report, the Commission emphasised the multidimensionality of well-being. On this basis, the OECD developed an initiative to measure well-being, creating the Better Life Index at the national level, with a regional breakdown to measure local well-being. Each person benefits from and contributes to his or her territory: the regional well-being framework is based on 11 dimensions of well-being and includes outcome indicators on material conditions, quality of life and subjective well-being. Regional well-being has been measured for more than 400 OECD regions and the data presented via an interactive website: www.oecdregionalwellbeing.org.

Eight French regions rank among the top $20 \%$ of OECD regions for health: the inhabitants of the capital region have the longest life expectancy in the country and one of the highest in the OECD area as a whole (Figure 2.6). The most significant regional disparities are observed for the community metric (perceived social support network), access to services (for which the baseline indicator is household broadband access), and safety, with Corsica in the bottom 25\% of OECD regions and Brittany in the top $25 \%$. Furthermore, Corsica ranks first among French regions for community, and the Sud region ranks first for life satisfaction.

Source: OECD (2020), www.oecdregionalwellbeing.org.

Figure 2.6. Disparities in well-being between the French regions relative to OECD regions

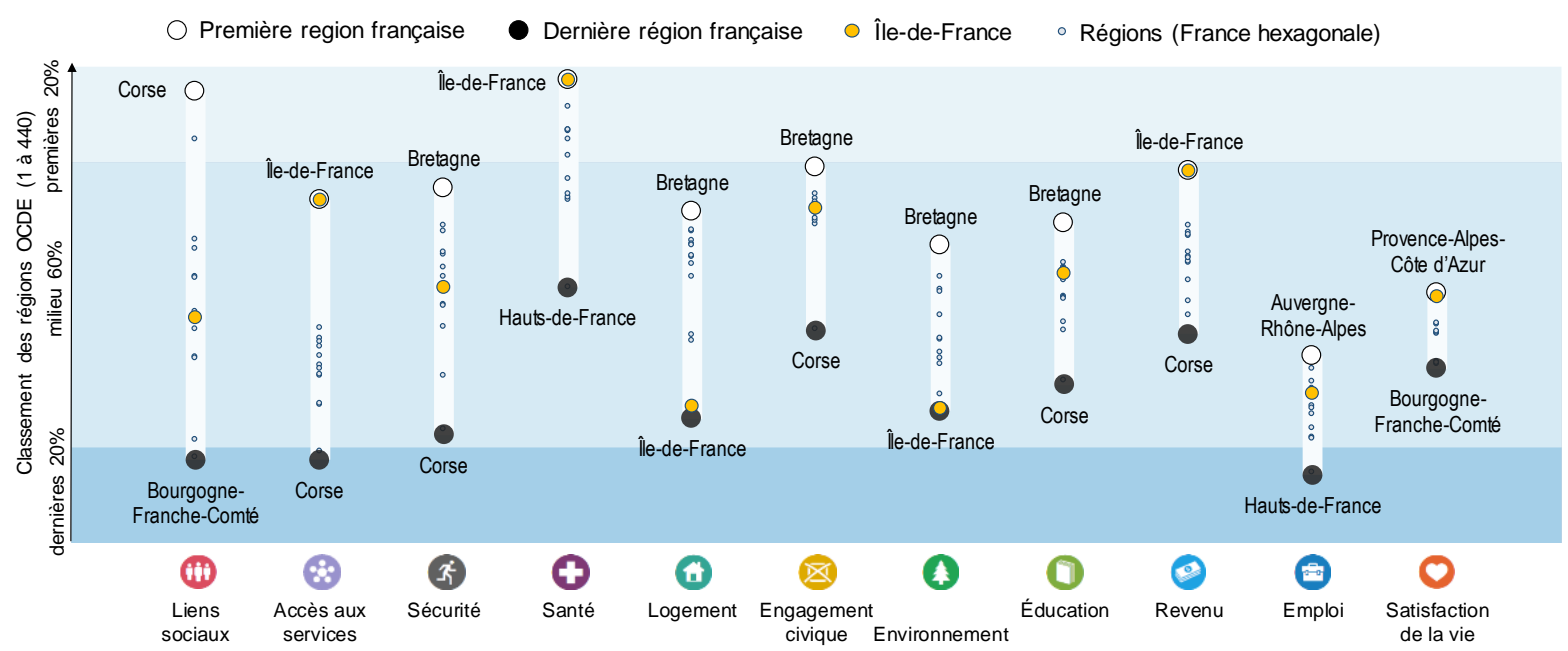

Note: Relative ranking of regions according to their results for the 11 dimensions of well-being, for all 440 OECD regions. The 11 dimensions are ranked in descending order of regional disparity in France.

Source: OECD regional database.

- The regions are also focused on supporting their businesses to export. This approach aligns with the findings of evaluations of export support programmes, which not only show a significant positive impact on business performance, particularly for SMEs (Munch and Schaur, 2018), but also an increase in business resilience (Van Biesebroeck et al., 2016). 
- However, there seems to be a disconnect between this support and another target of internationalisation strategies, with which it could well have more relevant linkages: foreign investors. A region's SMEs and their exports could be considered as "showcases" or "messengers" of their home territory's performance. As such, they could attract foreign investors or enable other potential SME exporters to benefit from this reputation.

- While attractiveness and export projects, and even support for tourism, hold an important place in the SRDEII, interest in meeting immediate local labour market demand by attracting and integrating foreign talent is largely absent from the SRDEIl strategies, despite their recognition of regional shortages in the digital professions and certain key sectors (such as agriculture).

- The SRDEII fairly uniformly refer to other strategic documents dealing with planning (SRADDET), tourism (Regional Scheme for the Development of Leisure and Tourism) or research and innovation (Strategy for Higher Education, Research and Innovation). It would be very useful to have a single summary document, ${ }^{50}$ pushing regional development programmes to integrate their various policies, including on internationalisation, into a single strategic vision to harmonise regional priorities and align them with national and European strategies. Such a reference document (which could, for example, consist of an "expanded" SRDEII) would improve efficiency by forcing the different actors to develop synergies.

Notwithstanding the observations above, the strategic focus areas set out in the SRDEII take on a new dimension in the context of the COVID-19 pandemic. By emphasising the desire to ensure that essential resources are available, the crisis is pushing regional actors and their national partners to question, as a priority, their position in global value chains - a dimension that is not central to most of the SRDEII. This relates not only to attracting foreign capital, but also to ensuring that foreign investment creates sustainable jobs in the businesses located in the region, as well as in the regional SME ecosystem, and that such investment supports local innovation. ${ }^{51}$ There is also the question of guaranteeing access to essential resources and ensuring the economic and social survival of the businesses in their territories (especially when these depend on exports or imported components).

Lastly, and crucially in the context of the European Green Deal, it is a question of the growing preference for a more sustainable and inclusive economy that enhances international trade relations (with the temptation to adopt "precautionism" rather than "protectionism") (Lamy, 2020) and the need to secure the expertise and knowledge for digitalisation and to respond to the challenges of ecological transition (especially climate and biodiversity).

In their SRDEII, drawn up well before the pandemic, some regions positioned their internationalisation strategy as a central lever of their development strategy. This is the case for certain overseas regions, which sought to integrate more actively and profitably into their surrounding ecosystem, internationalised by their very nature, and for the Grand-Est region, which aims to improve its trade balance, while attracting more foreign talent and increasing international co-operation in R\&D.

The economic crisis is likely to increase the territorial disparities within States (and regions), already exacerbated by the 2008 global financial crisis. When drafting this first generation of SRDEll, most regions (13 of 17) were already paying particular attention to territories experiencing challenges, including a territorial component providing for specific support and services in a context of internationalisation. These include: mountain territories in Auvergne-Rhône-Alpes and Corsica, rural

\footnotetext{
50 Some regions have made this an objective: for example, Martinique plans to produce a single document, the Land Use and Sustainable Development Plan (PADDMA), of which the SRDEII would form the economic component.

${ }^{51}$ According to Lembcke and Wildnerova (2020), while FDI allows businesses and their local ecosystem to integrate into global value chains through a spillover effect, it has a very limited positive effect on employment in SMEs, and may even have a negative effect for regional SMEs.
} 
towns in Martinique, certain departments in the Sud region, and urban political territories in Île-de-France that are often covered, along with territories in French Guiana, by national support programmes.

To what extent has the COVID-19 pandemic disrupted the SRDEII priorities and any changes they may have undergone since being drawn up? If there is one thing the OECD analyses can be certain of, it is that the current crisis - which is no longer simply a health crisis, but also an economic and social crisis requires an integrated and coordinated State-region approach to internationalisation (OECD, 2020b). In this regard, the SRDEII do indeed set out multi-objective public policies and some innovative governance mechanisms, which go beyond simple sectoral measures and involve actors beyond the regions alone. The following section presents these integrated policies and the governance mechanisms proposed by the regions to implement their internationalisation strategy. To this end, it begins by recalling that responsibility for internationalisation is split between administrative levels (economic development is the jurisdiction of the regions; commercial real estate is the jurisdiction of the intercommunal authorities; and infrastructure, attractiveness and export policies fall to central government).

In addition, the SRDEIl demonstrate the openness of the French regions to working across territorial boundaries with neighbouring and frontier regions to support their businesses and territories.

The measures put in place to co-ordinate the different internationalisation policies and the different actors at different levels of government have, thus far, aimed to make the most of the territories' internationalisation potential. They must now respond to the consequences of the pandemic on regional development in a new global environment.

\subsection{Multilevel governance of regional internationalisation policies}

The regions do not act in isolation to promote the internationalisation of their territories. They participate in the multi-level governance of internationalisation with that national government, sub-national actors and, at the core, businesses. The governance of internationalisation is crucial, so that actors at all levels of government can collectively respond to megatrends - climate, demographic and technological change (OECD, 2019c) - as well as to new challenges linked to the COVID-19 pandemic, which are likely to continue to increase disparities between regions, and between the territories within them. This section focuses first on the governance mechanisms for internationalisation strategies set out in the SRDEII. It then presents - as examples of the multilevel governance of internationalisation policies - national measures in which the regions are involved that target exports and attractiveness, logistics, and digital infrastructure.

\subsubsection{SRDEII: The regions' proposals on multilevel governance of territorial internationalisation}

The SRDEII themselves are an exercise in multi-level governance. The NOTRe law (see above) requires specific consultation with the EPCl, debate within the Territorial Conference on Public Action and the mandatory involvement of certain actors in developing the Plan (article 4251-14 of the CGCT). The regions do not limit themselves to the legal requirements; they go further by extending consultations to private actors and civil society, running thematic consultation workshops, and launching online consultations.

The legal framework governing the SRDEll encourages such partnership because it provides for the monitoring of implementation, involving at least the Regional Chamber of Commerce and Industry and the Regional Chamber of Social and Solidarity Economy (CRESS). Nevertheless, not all regions have indicated in their SRDEII how this monitoring and evaluation is to be conducted. ${ }^{52}$

\footnotetext{
${ }^{52}$ Nine regions provide detailed evaluation measures, while all regions mention the consultation mechanisms that fed into the SRDEII. In addition, the Sud region produced a follow-up evaluation of the progress of the SRDEIl after two years - see Deliberation No. 19581 of the Regional Council).
} 
The inclusion of the SRDEIl in both existing and more innovative multilevel governance mechanisms demonstrates the partnership dimension (particularly the State-region contracts or European programmes promoting knowledge connections). More innovative mechanisms mainly cover exports and territorial attractiveness, as well as territorial marketing, which is systematically included in all the SRDEII (see Box 2.2).

\section{Box 2.2. SRDEll: Territorial marketing and internationalisation strategies}

The SRDEII reflect a shared desire to strengthen the territorial marketing undertaken by the regional development agencies (Choose Paris Region; Made in Centre-Val de Loire, etc.). These initiatives are relatively detailed in 10 of the 17 regions, and aim to highlight specific regional assets to investors, talent and visitors.

Some regions seek to base their marketing on a general "regional brand" or use the national brand Choose France/Made in France (Paris Region, Invest in Réunion/Made in France; BIG EST in the Grand-Est region) or a label that can be applied to different sectors and activities (Martinique, Occitanie, Bourgogne-Franche-Comté, Centre-Val-de-Loire, Nouvelle Aquitaine, Auvergne-Rhône-Alpes and Brittany).

The regions are keen to develop their brand (non-price competitiveness), as well as their own identity (based on their "comparative advantages", as highlighted by Guadeloupe) at the international level.

In this context, the regions either want to be on the front line of developing a regional brand (Normandy) or to act as coordinators - or an "umbrella brand" - for the different marketing strategies of sub-national actors (Corsica and Pays de la Loire).

Source: The SRDEIl of the 17 regions.

In the SRDEII, the regions indicated their willingness to set up ad hoc export bodies (task forces, thematic or strategic committees, revamped export helpdesks - Corsica, Bourgogne-Franche-Comté, Sud and Occitanie), often involving businesses. Attractiveness policies can also be implemented by a wide range of public and private actors (CorsicaNetworks; "G20" and "C100" of the Grand-Est region) or more narrowly focused entities (Special Committee for the Revitalisation and Re-industrialisation of Hauts-de-France, ${ }^{53}$ Strategic Attractiveness Committee of Occitanie ${ }^{54}$ ). The multitude of attractiveness measures planned is illustrated in the Sud region's SRDEll in particular (see Box 2.2).

Despite being on the front line when it comes to exports and/or attractiveness, the regional development agencies, understood in the broadest sense, ${ }^{55}$ are not the only bodies that implement regional internationalisation. They act as part of a broad body of internationalisation actors, outlined by the regions in the SRDEII, but seem to be confined to either export policies or attractiveness policies (Hauts-de-France, Pays de la Loire and Occitanie), or to both (Corsica, Auvergne-Rhône-Alpes, Centre-Val de Loire and

\footnotetext{
${ }^{53}$ Introduced in the Hauts-de-France region's SRDEII, on 31 May 2016 the Minister of the Economy and the President of the Hautsde-France Regional Council entrusted this mission to Philippe Vasseur, Special Commissioner for the Revitalisation and Reindustrialisation of Hauts-de-France (2016-17), with a team that includes State services, Regional Council services, the services of the Nord-de-France Chamber of Commerce and Industry, public banking institutions, and the Nord France Invest agency (République française, 2017).

${ }^{54}$ This committee is composed of the region (president, vice president for the economy, vice president for attractiveness and vice president for tourism) and its agencies; the State (prefect) and its Business France agency; the local authorities representing the 18 employment areas (two metropolitan areas, conurbations, other EPCl), and 10 to 15 managers of foreign-financed businesses.

${ }_{55}$ For example, the risingSUD economic development agency (which replaced the Regional Agency for Innovation and Internationalisation in 2019) is considered the region's "secret weapon", founded by the regional Chamber of Commerce and Industry, together with the national government, Bpifrance and the Caisse des Dépôts Group (see Box 2.5).
} 
Nouvelle-Aquitaine, for example). ${ }^{56}$ Even when their remit is extended - as in the case of Auvergne-RhôneAlpes $^{57}$ - they are not responsible for an integrated portfolio covering the different internationalisation targets (investors, talent and visitors). It will be important to see whether this has changed during the next stage of this work.

The regions also emphasise the importance of coordinating between levels of government to ensure that internationalisation policies are successful. In 16 of 17 cases, the regions mention the need to act together with the national authorities, their agencies and their decentralised services, in particular Business France, Bpifrance, DIRECCTE, ${ }^{58}$ Customs, etc.

All the regions also mention the need for co-operation with sub-regional authorities, especially metropolitan areas, as well as economic actors, such as the chambers of commerce and industry.

Lastly, five regions add inter-regional horizontal co-ordination to this vertical co-ordination. The Pays de la Loire region, for example, plans to organise regular consultations on tourism with the neighbouring regions of Nouvelle-Aquitaine, Brittany and Centre-Val de Loire, while the Île-de-France region plans to build interregional competitiveness hubs and develop its focus on the Seine with neighbouring regions. NouvelleAquitaine asserts that "a territory's attractiveness (or competitiveness) can no longer be analysed in isolation. It is nourished by the territory's own performance and the performance of neighbouring territories, which have access to other assets, such as the dynamics of their industrial fabric and services" (NouvelleAquitaine region, 2017).

There is no "standard" multilevel governance model for internationalisation, especially when it comes to the national level. Guadeloupe proposes creating "a governance body that brings together the region, the department, the EPCl and the national government", known as the "G9"; the Pays de la Loire region plans to "increase collaboration with Business France"; and Nouvelle-Aquitaine proposes "a regional observatory for international trade and development" co-led by the region and the regional Chamber of Commerce and Industry. These elements also demonstrate the regions' expectations regarding the clarification of multi-level public action to promote internationalisation. The SRDEll therefore do not mention the extent to which the (at that time recent) reforms (particularly in terms of exports and attractiveness) met the regions' expectations for co-operation with other levels of government, in particular central government (see Section 3.2.2).

In addition to involving national actors, the multilevel governance proposed by the regions has a specifically international dimension. First and foremost, the SRDEII fall within the framework of European co-operation schemes (the Horizon 2020, COSME and LEADER programmes for this first generation). ${ }^{59}$ While the regions - which have managed European funds since 2014 - work in co-ordination with national authorities (especially the ANCT), these programmes broaden their range of European partners. The regions also propose to maintain, consolidate or extend existing cross-border and decentralised co-operation schemes (French Guiana, Corsica and Occitanie) (see Box 2.3 on decentralised co-operation). For other frontier regions, institutional innovation is embodied in various specific schemes, such as the creation of crossborder activity zones (Grand-Est and Bourgogne-Franche-Comté); the dual location of businesses (Auvergne-Rhône-Alpes); joint bodies for dialogue and political intermediation at the European level (Grand-Est and Auvergne-Rhône-Alpes); or schemes to support exports or economic development (Hauts-

\footnotetext{
${ }^{56}$ Corsica has proposed establishing an internationalisation adviser post at the Corsican Economic Development Agency. In Nouvelle-Aquitaine, the Nouvelle-Aquitaine Development and Innovation Agency focuses on 11 sectors for export and investment. 57 The Auvergne-Rhône-Alpes region has proposed merging the two former Rhône-Alpes and Auvergne regional development and innovation agencies. The new body would be responsible for economic development, innovation, territorial attractiveness and marketing, employment and training and the international dimension. On the other hand, the SRDEll specifies that the Regional Tourism Committee will retain its prerogative over visitor policies.

${ }^{58}$ DIRECCTE: Regional Directorates for Business, Competition, Consumption, Labour and Employment. These are a decentralised service shared by the Ministry of Economy and Finance, and the Ministry of Labour, Employment, Vocational Training and Social Dialogue.

${ }^{59}$ Brittany asserts, for example, that the Horizon 2020 programmes will make it possible to link innovation and exports. Corsica intends to strengthen engineering support for businesses and associations through a task force to support European projects, which will be responsible for facilitating and coordinating initiatives in Corsica.
} 
de-France and Grand-Est).

\section{Box 2.3. Regional participation in international agendas}

For many regions, the SRDEII constitute the economic pillar of their regional development strategy. However, their international component does not cover the full range of the regions' international commitments.

The regions contribute to sustainable development agendas in particular. Although the vast majority of the SRDEII do not specifically refer to the Sustainable Development Goals (2015) or the Paris Agreement (2016) - the cornerstones of sustainable development agenda established by the international community (and which are acknowledged in the SRADDET) - 14 of the 17 regions address the effects of economic development on resource conservation and how to harness the policies developed to grow the "green" and "blue" economies. Martinique, for example, is considering how to make the most of its "environmental heritage, an undeniable seedbed for activities with high added value, while ensuring that ecosystems and biodiversity are protected" and "become drivers for greater international visibility"; while the Centre-Val de Loire region states that each of its proposed policies including on internationalisation - will be based on sustainable development.

In addition, the regions are implementing decentralised co-operation programmes in multiple sectors with many partner territorial authorities. Since 2015, the regions and other territorial authorities have been reporting the official development assistance they receive by responding to surveys conducted by the National Commission for Decentralised Cooperation (CNCD). ${ }^{60}$ The CNCD provides guidance on reporting and information related to the cofinancing of projects. The Delegation for the External Action of Local Government (DAECT), a body within the Ministry for Europe and Foreign Affairs, has led the PACT3 programme since 2011. This programme certifies the technical expertise of French territorial authorities and helps them to establish decentralised co-operation partnerships for sharing expertise at the international level.

Lastly, the regions contribute to other international agendas within their territories, such as the Global Compact on Refugees (2018). Although managing migration and assisting refugees remains a national prerogative, some regions have promoted the integration of asylum seekers and beneficiaries of international protection. For example, the Occitanie region provides financial support to communes, public establishments and reception centres that have signed agreements with the national government to provide decent reception conditions for these populations and facilitate their integration, particularly into the labour market. ${ }^{61}$

Source: OECD (2018), Reshaping Decentralised Development Co-operation: The Key Role of Cities and Regions for the 2030 Agenda, OECD Publishing, Paris, https://doi.org/10.1787/9789264302914-en; OECD (2019d), "Decentralised development co-operation: Unlocking the potential of cities and regions", https://doi.org/10.1787/e9703003-en.

\subsubsection{Other partners in regional internationalisation}

This section aims to clarify the allocation of responsibilities and the relationships between levels of government with respect to internationalisation.

(i) Other local authorities

\footnotetext{
${ }^{60}$ Chaired by the Prime Minister, the vice-presidency is held by a representative of the territorial authorities, and its secretariat is provided by the Delegation for the External Action of Local Government (DAECT) within the Ministry for Europe and Foreign Affairs. ${ }_{61}$ Projects supported by the Occitanie region include French language learning, psychological support, interpretation, support in rural areas (home help, mobility assistance), training and job seeking (Région Occitanie, 2020).https://www.laregion.fr/Soutien-a-l-accueilet-a-l-integration-des-demandeurs-d-asile-et This approach has been evaluated by the OECD and has also enabled good practices to be shared with other European regions (Catalonia in Spain and Lazio in Italy).
} 
At the sub-national level, the regions' areas of responsibility are linked to those of other territorial authorities. The regions have jurisdiction over business support (assistance in creation/takeover and development, including support for export, which is paid directly to businesses or via partner organisations, such as Bpifrance). The communes and EPCI, including the metropolitan areas, are responsible for creating and extending economic activity zones and supporting commercial real estate (the region can provide additional assistance and financial support). The metropolitan areas also have jurisdiction over economic development (conferred by the Law for the Modernisation of Territorial Public Action and the Affirmation of Metropolitan Areas - the MAPTAM law - of 27 January 2014). The SRDEII focus areas for internationalisation nevertheless provide a policy framework for the metropolitan areas (after consultation), even though, in the absence of agreement with the region, these metropolitan areas may draw up their own strategy document, taking the regional plan into account (articles L. 4251-15 and L. 4251-17 of the General Local Authorities Code).

There are three types of territorial authority within France's decentralised administrative structure: communes, departments and regions. We can also add the EPCI and their equivalents in the metropolitan areas (greatly strengthened by the MAPTAM law). The SRDEll of the lle-de-France region sets out the division of responsibilities among local authorities as regards supporting businesses and the real-estate industry, levers for territorial internationalisation, as explained above. Even within these areas of responsibility, the sub-regional actors' room for manoeuvre differs depending on the type of support, which shows how complex implementing their responsibilities can be.

(ii) The national government

The French regions have significant jurisdiction over economic development, and spend relatively more on their economic development than most regions in other OECD countries (except Norway and Poland), as mentioned above. That said, their budgets, expenditure and investment ${ }^{62}$ remain low compared with the regions of other OECD countries. Figure 2.7 shows that the expenditure of the French regions in 2016 was among the lowest of the OECD countries. ${ }^{63}$ Against this backdrop, implementing internationalisation strategies requires the national authorities to be involved. The national authorities - via decentralised government services such as the Regional Directorates of the Environment, Land-Use Planning and Housing, and the Regional Directorates of Cultural Affairs - are in charge of the environmental authorisation needed to establish foreign companies in France. Co-ordination between central government and the region is therefore necessary, both for financial and regulatory reasons.

\footnotetext{
62 In 2016, investment by the French regions accounted for around 5\% of government investment and less than $0.2 \%$ of GDP, i.e. the lowest rate among the regions of unitary OECD countries.

${ }_{63}$ The French regions' expenditure is low relative to other sub-national authorities (11.3\% of territorial authorities' total spending in 2016), one of the lowest levels among unitary OECD countries - only the regions of Turkey, New Zealand, the Netherlands and Poland spend proportionally less - see OECD (2020e).
} 
Figure 2.7. Regional expenditure as a percentage of GDP and of total public expenditure (2016)

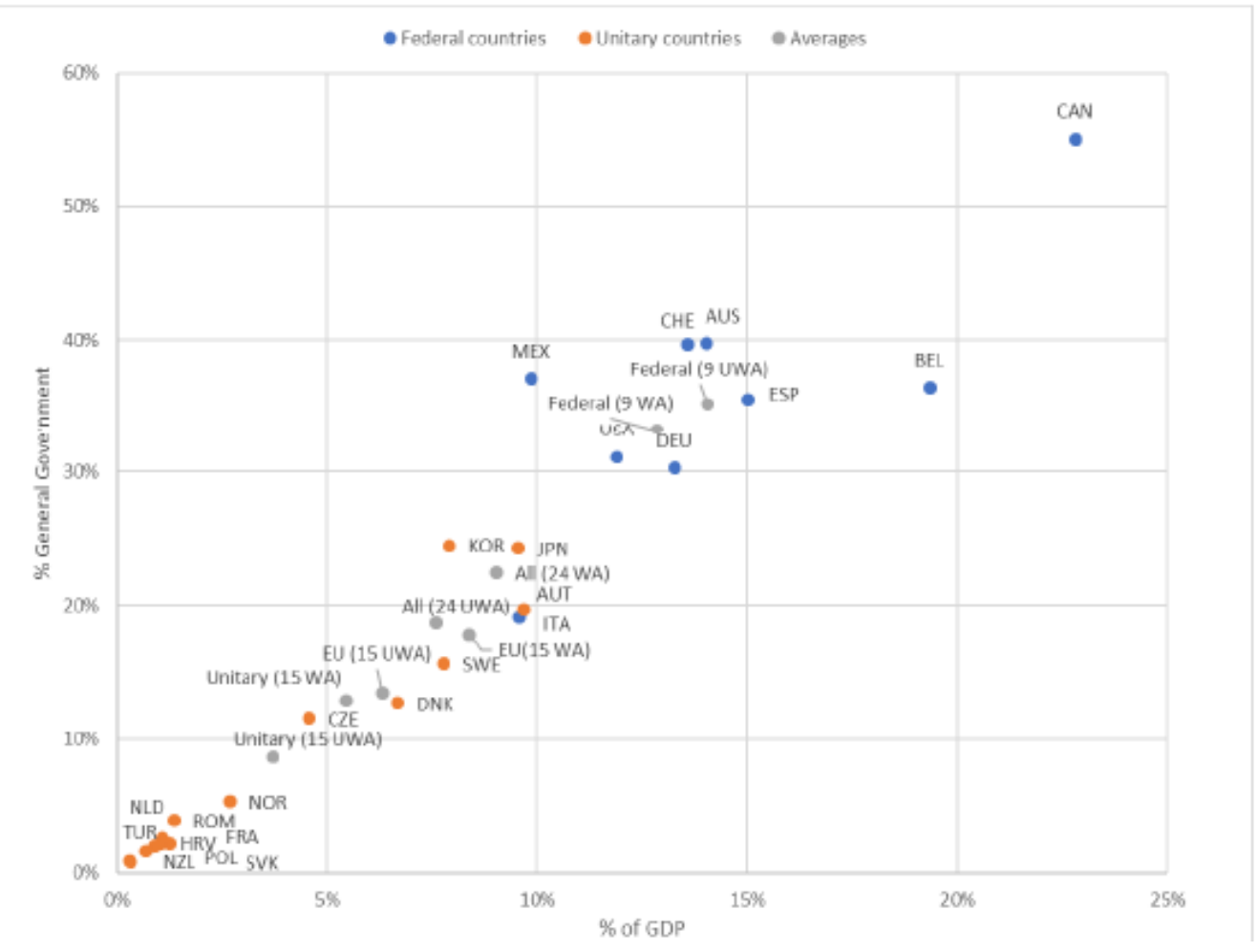

Source: OECD Regional Government Investment and Finance Database

The State is a major driver of internationalisation, whether through supporting French companies to export or identifying and welcoming foreign investors, talent or visitors. Several major reforms at the national level foster collaboration with the regions to promote internationalisation. In particular, in April 2019, the national government expressed its desire to "transform relations between central government and the territorial authorities." This transformation is ongoing and has been adapted to the context of the global pandemic, with the publication in December 2020 of the "4D" reform bill (deconcentration, decentralisation, differentiation and decomplexification) (Vie Publique, 2020).

\section{Box 2.4. The role of the National Agency for Territorial Cohesion in regional internationalisation}

On 1 January 2020, the National Agency for Territorial Cohesion (ANCT) ${ }^{64}$ was established by the General Commission for Territorial Equality (CGET) and placed under the supervision of the Ministry for Territorial Cohesion and Relations with Local Government. The ANCT's mandate is to advise and support sub-national authorities to carry out their duties, with the aim of reducing territorial disparities, in particular through better access to broadband infrastructure. The ANCT is a national agency that represents the national government throughout France and which, thanks to its decentralised services, can support the different actors - the territorial authorities and the national government - to achieve the complementary objectives of regional development policy, including on internationalisation. In particular, the Agency is responsible for liaising and signing contracts with sub-national governments. To support regional internationalisation and attractiveness policies, the ANCT co-ordinates a network

\footnotetext{
${ }^{64}$ The ANCT amalgamates the CGET, the ANCT Digital Agency - now the Sub-Directorate-General for Digital Technologies - and Epareca. The CGET already had some jurisdiction as regards internationalisation, such as digital inclusion, support for mobility, economic attractiveness, ecological and digital transition, and rejuvenation of fragile territories and city centres in decline.
} 
of sub-national actors (such as the clusters and competitiveness hubs involved in innovation policies) and operates as an inter-ministerial body, in close partnership with a number of internationally oriented actors, such as Business France and Atout France. The ANCT is also the co-ordinating authority, in cooperation with the ministries and sub-national authorities, for European structural funds (in particular the European Regional Development Fund) - which the regions consider one of the major levers of internationalisation. 65

Source: ANCT (2019; 2020); OECD (2019), "France", in OECD Regional Outlook 2019: Leveraging Megatrends for Cities and Rural Areas, https://doi.org/10.1787/9e936eee-fr.

With regard to its export promotion policy, the French government presented its external trade strategy in Roubaix on 23 February 2018 (French Republic, 2018). This strategy aims to streamline and simplify France's economic attractiveness at the international level. The then Prime Minister's speech highlighted the need for co-ordination between levels of government to better support companies in their export activities and to attract foreign investment as "two sides of the same coin." In this new context, the regions are responsible for defining and steering international development strategies, reaffirming the focus areas set out in the SRDEII.

\subsubsection{Current State-region co-ordination on regional internationalisation: Public policy examples}

The following sections use maps to illustrate the regulatory organisation of co-ordinated action by central government and the regions to increase exports and attractiveness. Examples of other dimensions of internationalisation are then provided to briefly outline the multilevel action taken by national and subnational authorities through policies to promote digital connection and port infrastructure.

\section{Business export support strategies (including the Team France Export scheme).}

At the national level, territorial strategies to support exports, including the Team France Export (TFE) scheme run by Business France, are steered and jointly supervised by three ministries: the Ministry of Economy and Finance, the Ministry for Territorial Cohesion and Relations with Local Government, and the Ministry for Europe and Foreign Affairs. ${ }^{66}$ These ministries undertake various supervisory activities in relation to the main export bodies - Business France, the French Chambers of Commerce and Industry ( $\mathrm{CCl}$ France) and Bpifrance, which are represented at both the national and regional levels. The vision set out by the government in the "Roubaix speech" mentioned above is embodied in the Team France Export scheme, which aims to increase the number of exporting companies in France, including first-time exporters, and consequently the volume of exports. This Team France Export scheme is being gradually rolled out in each region (often hosted in the premises of the Regional Chambers of Commerce and Industry). It is led by Business France and brings together the French Chambers of Commerce and Industry, the International Chamber of Commerce (ICC) and Bpifrance under the supervision of the region as the entity responsible for the business internationalisation strategy. Team France Export relies on a pool of human resources from the Regional Chambers of Commerce and Industry ${ }^{67}$ and regional

\footnotetext{
${ }^{65}$ As such, the ANCT provides overall co-ordination between several European structural funds, including the European Regional Development Fund, the European Social Fund and the European Maritime and Fisheries Fund.

66 In particular, at the interministerial level, the Minister for Europe and Foreign Affairs oversees the Directorate-General of the Treasury (DGT) in external trade matters and also has joint authority with the Minister of Economy over economic services abroad (Ministry for Europe and Foreign Affairs, 2020).

${ }^{67}$ The objectives and performance contract signed by the France Chambers of Commerce and Industry network with its supervisory ministry, the Ministry of Economy and Finance, includes strengthening ties with Business France as part of Team France Export under Pillar 3 (supporting companies to go international). The contract also makes 159 Regional Chambers of Commerce and Industry advisers available to Team France Export (Ministry of Economy and Finance and CCI France, 2019).
} 
representatives from Business France ${ }^{68}$ and Bpifrance, ${ }^{69}$ within the framework of regional agreements, 14 of which have been concluded to date: Normandy, Hauts-de-France, Sud, Pays de la Loire, BourgogneFranche-Comté, Centre-Val de Loire, Nouvelle-Aquitaine, Auvergne-Rhône-Alpes, Ile-de-France, Occitanie, Grand-Est, Brittany, Corsica and the overseas regions (CCI France, 2019; Team France Export, 2020).

This one-stop shop makes it possible to direct exporting companies towards the appropriate services (legal, insurance, translation, recruitment, etc.), provided by 30 partners and networks, both public (Regional Directorate for Customs and Direct Duties) and private (commercial banks), to support their export activities (Team France Export, 2020). Thus, each company based in a target territory that is seeking to export should have access to a specialised international coach in its region who will be its adviser and point of contact within the public export promotion scheme.

At the same time, a shared customer relationship management (CRM) tool has been set up to support the 250 "Team France Export advisers" (Banque des territoires, 2019), ${ }^{70}$ as well as an online "solutions platform" to provide information on the support and services on offer (by public and private entities) and to refer businesses to the relevant contacts to support them in their export plans. ${ }^{71}$

The Team France Export scheme operates in 65 countries around the world and is delivered by a special correspondent appointed to support companies that export abroad. This correspondent may be a Business France representative (export office) or the Team France Export point of contact at a privately-owned company. ${ }^{72}$ While the overseas arm of the scheme is managed at the national level, the regional development agencies act in conjunction with the single Team France Export correspondent to promote "their" businesses abroad (e.g. by participating in international trade fairs, or organising prospecting visits, etc.) (see Figure 2.8). This figure shows the complex organisation of the schemes to support prospecting, in which Business France plays a pivotal role. This complexity is linked to the large number of institutions involved in the cross-cutting policy and is not a problem in itself. However, it requires a very effective coordination system based on: information sharing, common objectives, a multisectoral/interministerial approach, capacity being made available at the different levels, tailored financing, policy implementation at the right administrative level and transparent evaluation (Charbit, 2011).

Further information about this co-ordination system will be available in the regional case studies that will follow this first report.

\footnotetext{
${ }^{68}$ Team France Export is led by Business France, and was created as part of its reform, as reflected in the 2018-22 objectives and resources contract. The Team France Export scheme aims to increase Business France's activity in the territories through a gradual roll out in the regions.

${ }^{69}$ The partnership between Bpifrance, the regions and Team France Export enables the schemes managed by Bpifrance and cofinanced by the regions - such as "prospecting insurance" and credit insurance - to be harnessed more effectively.

70170 advisers are from the Regional Chambers of Commerce and Industry and 80 are from Business France.

${ }^{71}$ In particular, this platform provides digital tools and innovative tailor-made solutions to help different businesses launch, develop and accelerate their international growth. The platform aims to be a well-organised and relevant resource and advice hub, providing business with the answers they need. It seeks to articulate a network led by Team France Export and its partners that will meet the specific needs of companies. Lastly, it aims to offer each company its own unique pathway, while providing a link to those within the territory who are able to offer advice and support. See Team France Export (2020), https://www.teamfrance-export.fr/.

72 This point of contact then operates within the framework of a public service delegation, public service concession or approved supplier agreement. In 2019, concessions were granted in Belgium, Hungary, Norway, the Philippines, Morocco and Singapore (Banque des territoires, 2019).
} 
Figure 2.8. Institutional involvement in territorial policies to support exports (including Team France Export)

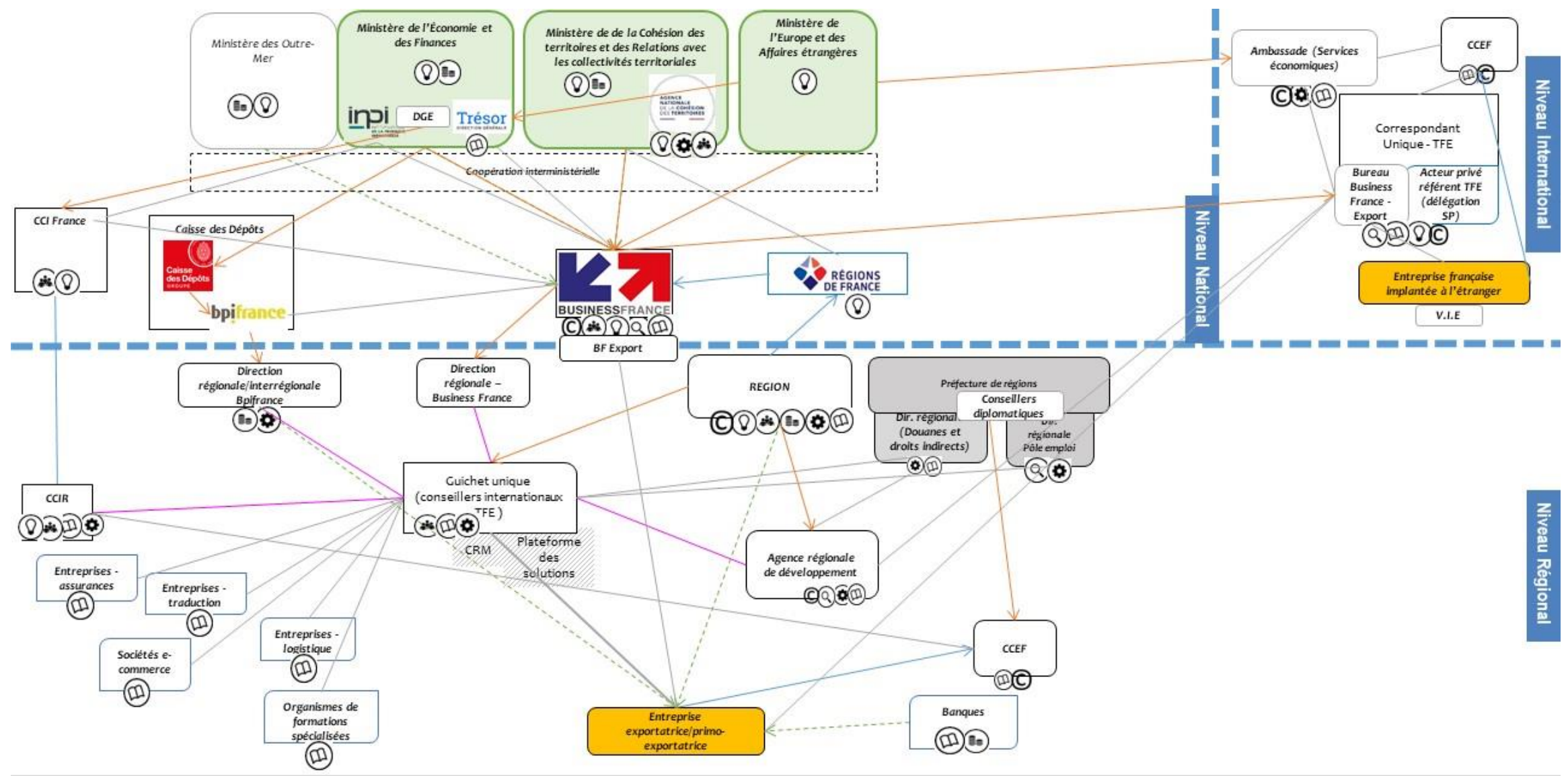

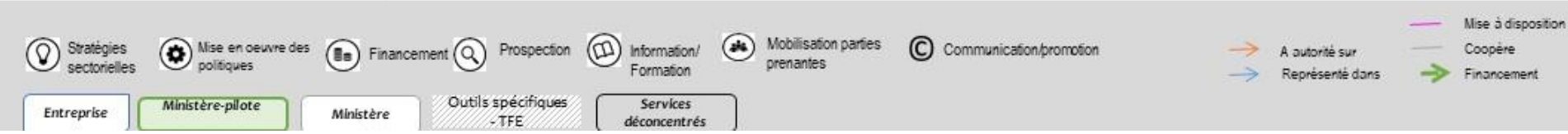

Source: Regulatory and strategic documents shared by the ANCT and the Ministry for Europe and Foreign Affairs; as well as online resources provided by the Ministry of Economy and Finance, Régions de France, Business France, French Foreign Trade Advisors, CCI France, and the Caisse des Dépôts Group.

REGIONS AND GLOBALISATION @ OECD 2021 


\section{Box 2.5. Team France Export in the context of the COVID-19 crisis}

Since the start of the COVID-19 lockdown, the Team France Export international advisers, based at the Chambers of Commerce and Industry, have published the International Business Barometer, drawing on input from more than 2600 French companies. In particular, the survey highlighted that $55 \%$ of exporting companies maintained their international activity during the lockdown period (as at $10 \mathrm{April}$ ). At the same time, it identified the main obstacles to exports during the pandemic (uncertainty about the future, logistics limitations - affecting both exports and supplies, a decrease in orders from abroad, etc.).

In addition, Team France Export has made more than 170 webinars available (by sector and by geographic area) as well as an interactive map listing the measures taken in export markets (business climate, level restrictions, changes in regulations, etc.) to help companies adapt their international strategy during the pandemic.

Lastly, the national economic recovery plan announced on 3 September by the French government includes an export component, with a total value of 247 million euros, which will mobilise the entire Team France Export apparatus and support the following measures:

- increasing the resources available for prospecting insurance, a highly sought-after tool among SMEs and ETIs as they start to export

- financial support to help SMEs and ETIs obtain export projections (such as when participating in international trade fairs, etc.)

- financial support from central government for an SME or ETI to send a candidate on a temporary assignment through the International Volunteer in Business (VIE) programme

- implementation of a market intelligence system, which will be personalised and free of charge for exporters, provided via the Business France interface.

Source: Business France (2020); Team France Export - Hauts-de-France (2020).

Strategy for increasing regional attractiveness at the international level (including the Team France Invest scheme)

In accordance with the NOTRe law, responsibility for attractiveness is shared between the regions and the EPCI (mainly metropolitan areas) (see Section 2.2.2). Nevertheless, as the Prime Minister indicated in the Roubaix speech, the national government plays a key role, particularly in attracting foreign investment.

At the national level, the three steering ministries - the Ministry of Economy and Finance, the Ministry for Territorial Cohesion and Relations with Local Government, and the Ministry for Europe and Foreign Affairs (which since 31 July 2020 has included a Minister Delegate for Foreign Trade and Economic Attractiveness $)^{73}$ - share responsibility for attractiveness ${ }^{74}$ as part of their respective supervision of the public bodies (Business France, Atout France ${ }^{75}$ and Bpifrance in particular). At the national level, significant interministerial work is also carried out by a steering committee that meets every two months, bringing

\footnotetext{
${ }^{73}$ Decree No. 2020-964 of 31 July 2020 on the powers of the Minister Delegate to the Minister for Europe and Foreign Affairs, responsible for foreign trade and economic attractiveness.

${ }_{74}$ In the field of tourism, the Ministry for Europe and Foreign Affairs has the Directorate General for Enterprise (DGE).

${ }^{75}$ To streamline action to promote France's economic attractiveness, the national government is considering merging Atout France and Business France in their representation abroad (pilot projects are being explored in Spain and the United Arab Emirates).
} 
together the "points of contact for attractiveness", ${ }^{76}$ under the authority of the Prime Minister's office. ${ }^{77}$ While the ANCT is a member of this committee, the regions are not represented.

State-region co-operation on attractiveness is mainly governed by two types of agreement:

- The National Charter for Foreign Direct Investment, ${ }^{78}$ to be applied in each region, stipulates that implementing strategies to attract FDI is primarily the responsibility of the regions, as "leaders", with the assistance of regional prefects, Business France and other public bodies and services. ${ }^{79}$

- The "Invest" agreements signed between Business France and the regional development agencies, which set out in detail the operating procedures for monitoring foreign projects (at the national and regional levels) as part of the Team France Invest (TFI) scheme, which, like Team France Export, is run by Business France. The creation of Team France Invest, modelled on Team France Export, was announced in spring 2018 to improve the effectiveness of the policy to identify and attract potential foreign investors to France. ${ }^{80}$

\section{Box 2.6. The organisation and territorial dimension of attractiveness in OECD countries}

Many OECD countries mobilise national agencies, working in co-ordination with territorial officials, to guide prospecting abroad, thereby avoiding overly intense regional competition and "zero-sum games" in which the success of some of their regions comes at the price of deregulation or territorial imbalances.

Links between different actors in the tourism sector and co-ordination between national promotion agencies and regional investment promotion strategies are generally still at the embryonic stage. In the best cases, one aspect of attractiveness has been flagged but the failure to look at the big picture means opportunities are missed to identify key institutional "hubs" and reap the benefits of synergies between policies with different targets. Efforts to map investment promotion agencies in OECD countries have underlined, for example, the need for the clear division of roles and responsibilities between levels of government for effective policy implementation. However, further research to compare national approaches is encouraged.

That said, a survey conducted in 2018 by the OECD and the Inter-American Development Bank identifies good practice in France, citing the strong co-operation between Business France and the regional investment promotion agencies, which is facilitated by a robust information-sharing mechanism.

Source: OECD (2018), Mapping of Investment Promotion Agencies in OECD countries, http://www.oecd.org/investment/investmentpolicy/mapping-of-investment-promotion-agencies-in-OECD-countries.pdf.

At the regional level, the prefectures and development agencies are the main actors when it comes to promoting attractiveness. Under the authority of the regions, which identify the priority sectors and territories for FDI as part of their SRDEII, the regional development agencies are the preferred contact for national actors within foreign investment project monitoring bodies, the Committee for the Orientation and Monitoring of Foreign Projects (COSPE) (see Box 2.7).

\footnotetext{
${ }^{76}$ The appointment of these points of contact follows the interministerial decision of 29 March 2018 to appoint a point of contact for attractiveness within ministries and central government.

77 The secretariat of this steering committee is provided by the Directorate General of the Treasury (Ministry of Economy and Finance)

78 This Charter was the subject of a Prime Minister's circular on strengthening the support system for foreign business investment and attracting foreign talent to France. Implementation of the Foreign Direct Investment Charter (14 December 2018).

${ }^{79}$ Two regional versions of the circular on the National Charter for Foreign Direct Investment have been signed to date, with the Centre-Val de Loire and Pays de la Loire regions, with the aim of extending these measures to all regions by the end of 2020 .

80 The agreement on the creation of the Team France Invest scheme was signed on 17 July 2018 between the General Directorate of the Treasury and Business France, alongside the Ministry for Europe and Foreign Affairs and the CGET.
} 


\section{Box 2.7. The Committee for the Orientation and Monitoring of Foreign Projects, the central body of the Team France Invest scheme}

The Committee for the Orientation and Monitoring of Foreign Projects (COSPE) meets weekly, led by Business France Invest's national office and the regional development agencies, to discuss requests from Business France's foreign offices for the establishment of new companies in France. These requests are circulated via SINPA, ${ }^{81}$ a platform shared by Business France and the regional development agencies.

The purpose of the COSPE is to steer projects towards the regions identified by these foreign investors (where applicable) based on the investors' requirements, e.g. space required, proximity of infrastructure, labour, etc.

During COSPE meetings, projects are examined and the regions decide whether they can make a regional offer that meets the investor's requirements. Two types of projects are considered: projects that do not specify regions in advance and projects targeting one or more regions.

The regional development agencies are asked to position themselves according to their regional priorities (as contained in their SRDEII). Some regional development agencies might, therefore, decide not to respond to requests from investors whose projects do not align with the strategic focus areas set out in their SRDEII.

When an investor targets several regions, Business France co-ordinates the offer by preparing, with the help of the regional development agencies concerned, a joint offer summarising the strengths of each region, with Business France taking care of the regulatory matters (harnessing national schemes, etc.). This offer is then relayed to the Business France Invest office abroad for negotiation with the potential investor. The regional development agencies are then required to organise a local visit to potential sites.

Source: Documents shared by the ANCT.

In addition to the national COSPE, the National FDI Charter provides for:

i. A regional COSPE, bringing together the regional development agency, which handles the operational dimension of attractiveness policies through prospecting, receiving and supporting direct investors; the regional authorities; the decentralised government services (mainly DIRECCTE and DREAL, under the co-ordination of the regional prefect); as well as the Special Advisor for Investments and the Commissioner for Productive Recovery, both attached to the General Secretariat for Regional Affairs (SGAR), and the Bpifrance Regional Directorate.

ii. A Regional Attractiveness Council, which brings together the regional authorities, the decentralised government services and foreign companies that are already established in the region (see Figure 2.9).

\footnotetext{
${ }^{81}$ The Committee for the Orientation and Monitoring of Foreign Projects' collaborative tool (a software package called SINPA/CRM), is shared by Business France, the agencies and Business France's foreign offices).
} 
Figure 2.9. Institutions involved in regional attractiveness policies (including Team France Invest)

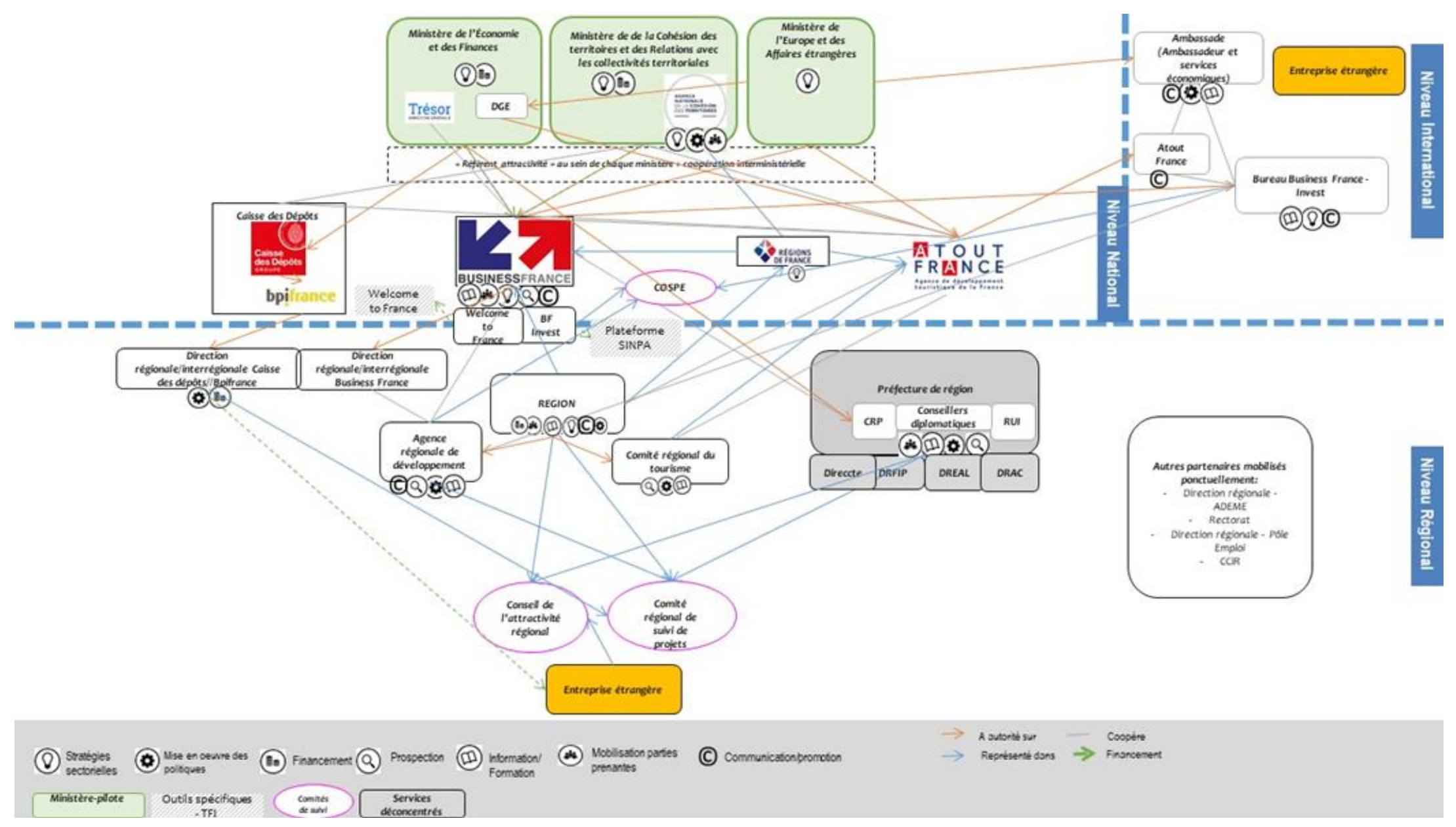

Source: Regulatory and strategic documents shared by the ANCT and the Ministry for Europe and Foreign Affairs; as well as online resources provided by the Ministry of Economy and Finance, Régions de France, Business France, Atout France, CCI France, and the Caisse des Dépôts Group.

\section{REGIONS AND GLOBALISATION ๑ OECD 2021}




\section{Box 2.8. The regions' attractiveness policies and their co-ordination with the national government in the context of the crisis}

France's attractiveness is growing, as evidenced by the 2020 EY Attractiveness Survey, which ranks France as the most attractive European country. However, the disruption caused by the COVID-19 crisis, such as tighter controls on foreign direct investment to protect strategic assets, may jeopardise this performance for 2020.

In response, the focus areas proposed by Business France in May 2020 were sent to the regional prefectures to be discussed with the regional development agency and, where necessary, adapted in line with regional priorities:

- safeguard jobs and the local ecosystem weakened by the crisis, in particular by finding foreign buyers for French companies in difficulty or in receivership

- better capitalise on the territories' existing assets, by strengthening the provision of advice on territorial marketing and by improving the follow-up of foreign investors in the territories, including measures to retain foreign investors despite value chains being reshored.

- create new opportunities for the territories: create and disseminate territorial offers adapted to the needs of investors and share international opportunities that arise from reshoring foreign companies' value chains or from European schemes.

In addition, the process of signing regional versions of the National Charter for Foreign Direct Investment should continue, as only two have been signed to date (Centre-Val de Loire, Pays de la Loire).

Furthermore, the regions have implemented measures to safeguard their attractiveness during the sudden downturn - or even halt - in international trade, particularly in the tourism sector. These measures relate both to attracting companies seeking to repatriate part of their supply chain and to retaining foreign companies already established in the country.

The France Relance recovery plan announced by the government on 3 September 2020 has therefore been designed as a "sovereignty accelerator" and will provide more than EUR 1 billion by 2022 to reshore and maintain economic activity through investment in the strategic areas of health, industrial inputs, electronics, agro-food and telecommunications (EUR 600 million), as well as support for reshoring industrial activities to the 148 "industrial territories" (EUR 450 million). While the recovery will centre around the territorial level, central government and the regional authorities are already working together to encourage the onshoring of economic activity, for example through the Industrial Territoires programme, ${ }^{82}$ which identifies regional opportunities for reshoring and supports the onshoring of certain sectors (such as flax spinning in Alsace) (Banque des territoires and ANCT, 2020).

The regions are also stakeholders in this recovery: the Grand-Est region has proposed a reshoring pact to encourage, assist and support companies seeking to repatriate part of their supply chain from Asia to the region, France or Europe. The Sud region plans to earmark EUR 17 million for onshoring as part of its regional economic recovery plan (EUR 4 billion). The Centre-Val de Loire region and its economic agency Dev'Up are working to repatriate activities in the pharmaceutical, cosmetics, agro-food, logistics and digital sectors; while the Occitanie region is developing a plan to reshore industry, with priority being given to the health, food, environment and energy sectors.

Source: Documents shared by the ANCT, European Commission (2020) and Saudemont (2020).

The COVID-19 pandemic has underlined the fragility of certain sectors that, nonetheless, are the drivers of regional economies (notably tourism), while simultaneously highlighting the importance of a co-ordinated response to the crisis so that the French regions can take advantage of new opportunities in the wake of 
the pandemic. To this end, the following section outlines two important channels for regional internationalisation: logistics and digital infrastructure.

\subsubsection{Other national strategies for territorial internationalisation}

\section{Logistics infrastructure}

The COVID-19 pandemic has highlighted the importance of logistics chains for withstanding the economic impact of this health crisis. Integrating the regions into the global ecosystem involves integrating them into global value chains, and therefore into logistics chains. Logistics chains are highly exposed to shocks (health crises, social movements, weather events, etc.), yet are also one of the most resilient sectors. The COVID-19 crisis, which blocked the movement of people but did not prevent the widespread movement of goods, illustrated this once again, as logistics chains coped relatively well with the crisis and thus helped to sustain activity in many of the key sectors of regional economies (Ministère de l'agriculture et de l'alimentation, 2020).

The COVID-19 crisis has also highlighted existing territorial disparities and some territories' dependence on others for supplies: three national routes transport $60 \%$ of goods, and the majority of warehouses and large-scale logistics platforms are concentrated in urban areas in the north of France (Paris and Lille in particular) and in Auvergne-Rhône-Alpes (Lyon) (Ministère de l'Environnement, de l'énergie, et de la mer en charge des relations internationales sur le climat, 2017). This situation has taken on a new dimension in light of the pandemic, as food security becomes a major concern for local and regional authorities (Régions de France, 2020).

The COVID-19 crisis has therefore increased the need to strengthen horizontal co-operation (between regions) and vertical co-operation (between central government, the regions and other authorities) to organise flows that are free from administrative borders. While some regions are particularly active in supporting territorial internationalisation through logistics infrastructure (Section 3.1.2 on the analysis of infrastructure connections in the SRDEII), the regions' jurisdiction over transport does not extend to goods, and their jurisdiction over economic development does not include logistics. Moreover, enhancing territorial internationalisation also requires better recognition of the shared geography of logistics infrastructure.

The country's port infrastructure in particular offers still relatively underexploited potential to strengthen French regions' position in international trade. The major seaports - Dunkirk, the Seine axis (Le Havre, Rouen, Paris) and Marseilles - create wealth and jobs that extend far beyond the perimeters of their ports. Although the major seaports were reformed in 2008 to refocus their activities on the economic and environmental development and enhancement of their sector, their governance has been called into question (Colrat et al., 2018). Most of the actors along the Mediterranean-Rhône-Saône axis support the idea of strengthening the governance of logistics infrastructure, however "such an approach is not necessarily simple, as the actors are widely dispersed and common practices remain rare" (Baudouin, 2018) (see Box 2.9).

\footnotetext{
82 The Industrial Territories programme, launched by the Prime Minister at the National Industry Council on 22 November 2018, is a national strategy for the industrial revitalization of the territories. The programme targets 148 industrial territories in mainland France and the overseas regions, comprising over 500 inter-communal areas with a strong industrial identity. These territories are brought together as partners to participate in joint projects to develop local industry. They benefit from a basket of services provided by the national government and its agencies (Banque des Territoires, Bpifrance, Business France, employment hub, Ademe and Action Logement) to channel resources to four key strategy areas: (i) attracting, i.e. promoting the attractiveness of the territories and industrial professions; (ii) recruiting, i.e. facilitating the training, recruitment and mobility of employees to meet companies' labour needs; (iii) innovating, i.e. supporting companies and territories through digital and ecological transitions; and (iv) simplifying, i.e. speeding up administrative procedures and facilitating the installation of industry, following the "turnkey site" model.
} 


\section{Box 2.9. Strengthening multi-level governance: The case of port infrastructure along the Mediterranean-Rhône-Saône axis}

The report of the Interministerial Delegation for the Development of the Mediterranean-Rhône-Saône Port and Logistics Axis aims to enhance port attractiveness and to develop the related logistics chains against the backdrop of increased global competition.

In France, the emergence of a port strategy to promote international attractiveness is hampered by the multiplicity of actors in the sector and by territorial segmentation. Such a strategy would strengthen the major global ports (Marseille, Dunkirk and the HAROPA port complex - the ports of Paris, Seine and Normandy); the decentralised ports (maritime and river); and the hinterland. Proposals to create a port system on the scale of the Mediterranean-Rhône-Saône axis include:

- consolidating the position of the Grand Port Maritime of Marseille as Mediterranean leader

- establishing a Mediterranean maritime front based on the assets of each of the ports and their complementarities

- improving the performance of the axis in terms of logistics and its connections with international flows

- building a productive and interlinked hinterland commensurate to the ambitions for the Mediterranean port complex created.

Lastly, this approach aims to strengthen the use of ports for external trade in the four regions involved (Sud, Auvergne-Rhône-Alpes, Occitanie and Bourgogne-Franche-Comté) as these regions mainly trade with Germany (Auvergne-Rhône-Alpes and Bourgogne-Franche-Comté) and outside the EU (Occitanie), rather than within the Mediterranean area, where Spanish and Italian ports dominate. ${ }^{83}$

This approach envisions a role for the regions within a national logistics plan, drawn up in consultation with the decentralised government services, with the region participating in a "Council of the Territories" alongside the national government and the other local authorities involved, as the scope of the StateRhône Interregional Planning Contract covering four axis regions expands.

Source: Baudouin, Jean-Christophe (2018), Propositions pour le renforcement de l'intégration de la gouvernance sur l'axe MéditerranéeRhône-Saône - Rapport à Monsieur le Premier ministre, Délégation interministérielle au développement de l'axe portuaire et logistique Méditerranée-Rhône-Saône (26 June 2018)

\section{Digital infrastructure}

France has a vast and diverse territory as well as a large rural area, accounting for $54 \%$ of its territory (OECD, 2018b), with housing outside the major cities widely dispersed. While urban households have efficient and competitive broadband networks, coverage in the lower density territories (and even the suburbs) is of direct concern to public authorities (Régions de France, 2019) and private operators. ${ }^{84}$ The Law on Confidence in the Digital Economy (2004) gave the regions and other territorial authorities the power to establish and operate electronic communication networks; the national broadband plan France Très Haut Débit then appointed them as the "driving force" in the roll out of very high-speed broadband (Arcep, 2020), ${ }^{85}$ first and foremost to help bridge the digital divide (Régions de France, 2020b). The regions

\footnotetext{
${ }^{83}$ The Sud region handles trade within the Mediterranean area, particularly with Italy.

${ }^{84}$ France's digital infrastructure sector comprises 130 companies and 150000 direct and indirect jobs, with EUR 10 billion invested in its networks (2017) (Conseil national de l'industrie, 2020).

${ }^{85}$ Arcep is an Independent Administrative Authority (IAA). It regulates the electronic communications and postal sectors on behalf of central governmental, but entirely independently of any political power or economic actor (Arcep, 2020).
} 
co-operate with national authorities via government programmes to improve mobile coverage, such as the national programmes run by the ANCT (France Très Haut Débit and Société Numérique) (ANCT, 2020); as well as via co-ordination bodies, such as the Regional Commission for Digital Society ${ }^{86}$ (CGET, 2017).

As regards fixed networks, the France Très Haut Débit aims to provide $100 \%$ of the population with highspeed access ${ }^{87}$ by 2022, as referenced by the SRDEII (Arcep, 2020). Operators able to supply fibre were invited to submit their individual plans for rolling out fibre to the home, as well as their plans for coinvestment. ${ }^{88}$ The regions and other territorial authorities are the contracting authorities for networks that have at least departmental scope in the less densely populated areas, i.e. $80 \%$ of the national territory; they run competitive tenders that most often result in public service delegations, or where appropriate, concessions. According to Régions de France, 3 to 4 million homes and businesses still need to be connected to fibre by 2025 , the target year for nationwide coverage of this technology (Régions de France, 2019).

As regards the mobile networks sector, after major State action in 2003,89 the New Deal Mobile programme was initiated in 2018 , relying on private operators, ${ }^{90}$ to ensure digital mobile coverage for rural areas, which should enable $4 \mathrm{G}$ service to be provided to $99.6 \%$ of the population.

Digital development is essential for territorial attractiveness, competitiveness and equality. As a recent report by the Economic, Social and Environmental Council asserts, "never before have networks provided so many absolutely essential services: not having access to them, or only at prices deemed discriminatory, leads to some being left behind" (Arav, 2020). The COVID-19 crisis has revealed the enormous potential demand for digital equipment and therefore for access to and improved use of digital technology. This demand comes both from SMEs and employees working from home, as well as in response to the range of "digitalised" public services (medicine, education, etc.), especially at the regional level (De Mello and Ter-Minassian, 2020). It remains to be seen whether rolling out digital infrastructure can actually change the status quo among the French territories, especially as the major metropolitan areas are the most affected by the pandemic (OECD, 2020c) ${ }^{91}$ but also the areas best suited to large-scale telecommuting (OECD, 2020e). Digital infrastructure could benefit other territories, especially small and medium-sized cities, including those located on the outskirts of the large metropolitan areas. The regions, supported by central government, will play an important role in ensuring that the digital shift enhances the diversity of their territories and urban-rural relations.

\footnotetext{
${ }^{86}$ Replacing the Commission for Regional Consultation on Digital Spatial Planning, the Regional Commission for Digital Society meets once a year at the request of the regional prefect to develop the existing systems and mobilise the local authorities, bodies and actors involved.

${ }^{87}$ While the European standard sets a threshold speed of $30 \mathrm{Mbps}$, the France Très Haut Débit plan aims to extend fibre (100 Mbps) to $80 \%$ of users.

88 In 2019, approximately 7000 communes had been covered.

${ }^{89} 3500$ communes have been equipped with passive infrastructure built by the public authorities, via which the four operators must provide their services.

${ }^{90}$ In the event of non-compliance, private operators are liable to substantial financial penalties imposed by Arcep.

91 This is due to restrictions related to clustering effects (density, etc.).
} 


\section{Conclusion: Towards a more integrated and coherent vision of regional internationalisation}

Understanding the regions' position in the global ecosystem is essential for enabling them to refine their development strategies, in countries where they have the flexibility to do so, and to adapt these strategies to the changing global context, affected as it may be by crises like the COVID-19 pandemic and its aftermath.

This report addresses the issue in three complementary ways:

- by proposing a statistical methodology

- by applying this methodology to the French regions

- by providing an initial analysis of internationalisation strategies, mainly based on the SRDEII, and the implementation of these policies within the framework of national programmes.

Identifying and analysing the regional internationalisation indicators (Chapter I) made it possible to propose an original methodology based on four families of indicators, each shedding light on a particular dimension of the connections linking the regions to the global ecosystem. These connections are:

- infrastructure connections (particularly transport networks and high-speed Internet access) that shape how the territories interact with the rest of the world

- human connections (especially visitors and immigrants) which make it possible to characterise short and long-term visitor flows and therefore to address an important component of local population diversity (which may include potential links with the territories of origin of the diasporas and talent present in the regions) as well as the weight of tourism activities in the regional economy

- knowledge connections (teaching, research and expertise) that position the regions in the global knowledge economy and attract international students and foreign research workers (which also links back to human connections and, above all, the capacity to be a hub for exchange, contributing to global innovation)

- business connections (especially exports and foreign direct investment as well as sectoral specialisation in goods and service open to international competition) that provide information about the position of local firms in the global economy.

Some of the data used only cover certain aspects of the phenomenon in question or only some of the OECD countries (sometimes only European countries, or even only French regions). Additional indicators should be included in this analytical framework, such as indicators on cultural goods proposed by the regions (museums, world heritage sites, festivals, etc.) and local innovation hubs in the knowledge connections family. These elements can be developed further if the data become available to provide a more comprehensive picture of regional internationalisation. 
In addition to the baseline indicators, statistical analyses would also shed light on the issues of territorial dependency and resilience in the context of the COVID-19 crisis and how to strengthen the response through the regional recovery plans currently under development. Additional metrics could include detailed economic data on companies' imports and exports at the territorial level to position the region in global value chains. As a number of academic works have shown (Antras et al., 2017; Beatie, 2020; Gershel et al., 2020; Barrot et al., 2020), the following indicators are also important for understanding local dependence on international trade: the diversity of specialised sectors and the size of economic actors; the diversity of their foreign trading partners; and the nature of the foreign companies present in the territory (head office or subsidiary).

An important outcome of this study is the "regional internationalisation profiles" which, based on the most representative indicators for each family of connections, make it possible to distinguish different regional situations. The "frontier regions" group underline the importance of close ties with foreign neighbouring regions to the international position of these territories. Although this dimension is key for the frontier regions of mainland France (especially Grand-Est and Hauts de France), it is not representative of the overseas regions. On the whole, despite being situated in international arenas (by their very nature) and aware of the advantage that this position gives them, the overseas regions seem to base their approach more on a range of public policies (broadband network, tourism) than on an internationally oriented approach. These overseas regions are not a homogeneous block but rather represent a range of specific situations. A last group of mainland regions is connected internationally but not in a way that indicates any major specificities at this stage.

These regional internationalisation profiles highlight the benefit of taking account of the different dimensions, which the regional authorities and their partners can harness to enhance their international development. This report analyses the varied range of internationalisation strategies (Chapter II) using the SRDEIl developed by the French regions in 2016-17 to map out their programmes of action to 2022. The SRDEII are reference documents showing the variety of approaches and projects, all of which, however, illustrate and confirm the relevance of the taxonomy of the connections proposed. That said, the SRDEII do prioritise the economic dimension of internationalisation (export support and attractiveness to foreign investors in particular) and the challenges of developing infrastructure (especially digital infrastructure).

The pandemic is disrupting these initial plans and it will be useful to revisit the projects outlined by the regions in the light of the search for short and medium/long-term responses to the consequences of the COVID-19 crisis. The disruption of value chains and the desire to limit dependence on key resources and sectors, giving rise to "reshoring" policies or at the very least to less just-in-time stock management, underline the extent to which internationalisation cannot be considered as an end in itself, but rather as a means for the regional authorities to improve the well-being of their inhabitants and the economic resilience of their businesses and local employment. These developments do not only concern the organisation of companies' international activities, they are part of a fundamental megatrend towards digitalisation (and automation) that is transforming patterns of production, work, consumption and leisure. Rather than acting as a brake, the pandemic, despite its tragic nature, seems to be playing a paradoxical role as an accelerator, strengthening the regional ambitions contained in the SRDEll to increase broadband access and Internet use in the territories.

It is very difficult to predict today what impact these varied trends will have on territorial disparities. However, they also present an opportunity for more balanced urban-rural development that is more conducive to the two major dimensions of well-being, as yet unmentioned: social cohesion (Algan and Cahuc, 2014) and the protection of the climate and biodiversity. The populations' expectations in this area might reshape the modus operandi of pre-pandemic globalisation, by pushing politicians to adopt more effective incentives for multinationals and other global operators to ensure internationalisation more effectively contributes to inclusion and respect for the environment. These expectations might also increase the adoption of policies for the integration of immigrants, which are hardly mentioned in the regions' current plans. The pandemic has indeed shown the high dependence on migrants and seasonal 
workers, both for the skilled occupations such as doctors, and the less skilled trades, such as delivery drivers, home help, cleaners or agricultural workers. As found by other OECD studies, it seems that territorial resilience depends on better reception of these populations, who are also more likely to create businesses and use their international connections for the development of their host territories.

These changes can emanate neither from a single area of international policy nor from the action of the regions alone, despite their jurisdiction over economic development and internationalisation. Against the backdrop of the territorial approach of the France Relance plan and following the framework agreement signed on 30 July 2020 between the national government and the regions, this report also highlights the mechanisms mentioned by the regions for implementing their internationalisation programmes by integrating different objectives and working with a wide range of relevant actors (businesses, public bodies and other local authorities in particular). This study also highlights that the regions' internationalisation strategies fall within the framework of national and European programmes whose effectiveness depends on high-quality multilevel governance that ensures coherent action. To illustrate this, we have mapped the institutions involved in policies to support exports and attractiveness underpinning the international economic development of the territories. Lastly, additional information underlines the role of the national government in regional infrastructure policies, using logistics chains, ports and the digital infrastructure at the territorial level as examples. These illustrations underscore the need to formulate internationalisation policies that complement other regional development policies. They also demonstrate the mutual dependence (Charbit and Michalun, 2009) of the national government and the regions when it comes to resilience in the "post-COVID" global environment, as well as the role that the supranational level can play in the case of European regions. ${ }^{92}$ Further study will enable us to deepen our knowledge by identifying difficulties and good practices and innovations on the ground, and to provide useful recommendations by comparing the case of the French regions with other OECD regions, particularly in Europe. It will highlight possible obstacles and good practices in devising and implementing regional internationalisation policies aimed at inclusive and sustainable development in the new global environment. One of the ANCT's missions is to support the regions to make their internationalisation strategies more resilient. Further study will provide conceptual and operational support for this mission.

\footnotetext{
92 In addition to approving a multi-annual financial framework for 2021-27, the European Union has announced ambitious recovery programmes that will provide a total of EUR 750 billion (Next Generation EU programme, Recovery and Resilience facility initiatives, Recovery Assistance for Cohesion and the Territories of Europe - REACT-EU), as well as strengthening programmes to support European regions (rural development programmes, Just Transition Mechanism, etc.) (European Commission, 2020b).
} 


\section{References}

Algan, Y., C. Malgouyres, C. Senik (2020), «Territoires, bien-être et politiques publiques », Les notes du conseil d'analyse économique, No. 55, Conseil d'analyse économique.

Allain-Dupre, D. (2020) "The Multi-level Governance Imperative" in the Special symposium on Multi-Level Governance, The British Journal of Politics and International Relations, Vol 22, Issue 4:753-936

ANCT (2020), "L'Agence nationale de la cohésion des territoires », https://www.cohesionterritoires.gouv.fr/lagence-nationale-de-la-cohesion-des-territoires\#scroll-nav 2.

ANCT (2019), «Édouard Philippe et Jacqueline Gourault présentent le projet de loi « 3D », $15^{\mathrm{e}}$ congrès de Régions de France, 8 octobre 2019, https://www.cget.gouv.fr/actualites/edouard-philippe-etjacqueline-gourault-presentent-le-projet-de-loi-3d

Annoni, P. et L. Dijkstra (2019), EU Regional Competitiveness Index, European Commission, Publications Office of the European Union, Luxembourg.

Annoni, P. - Dijkstra, L. (2013), European Regional Competitiveness Index.. European Commission, Publications Office of the European Union, Luxembourg.

Arav, Fanny (2020), L'impact des infrastructures de réseaux dans l'économie, Avis du Conseil économique, social et environnemental (mai 2020), https://www.lecese.fr/sites/default/files/pdf/Avis/2020/2020 08 impact infrastructures reseaux.pdf

Arcep (2020), La régulation de l'Arcep au service des territoires connectés, Rapport d'activité (mars 2020).

Banque des territoires (2019), « Team France Export : 26.000 entreprises accompagnées en région d'ici 2022 », https://www.banquedesterritoires.fr/team-france-export-26000-entreprises-accompagneesen-region-dici-2022

Banque des territoires (2017), " Développement économique - Quelle mise en oeuvre pour les SRDEII ? ", https://www.banquedesterritoires.fr/quelle-mise-en-oeuvre-pour-les-srdeii

Barrot, J N, B Grassi and J Sauvagnat (2020), "Sectoral Effects of Social Distancing", Covid Economics: Vetted and Real-Time Papers 3.

Batista e Silva, F et al. (2018). " Analysing spatiotemporal patterns of tourism in Europe at highresolution with conventional and big data sources", Tourism Management, No. 68, pp. 101-115, https://doi.org/10.1016/j.tourman.2018.02.020

Baudouin, Jean-Christophe (2018), Propositions pour le renforcement de l'intégration de la gouvernance sur l'axe Méditerranée-Rhône-Saône - Rapport à Monsieur le Premier ministre, Délégation interministérielle au développement de l'axe portuaire et logistique Méditerranée-Rhône-Saône (26 juin 2018)

Beatie, A. (2020) Be wary of scapegoating 'just-in-time' supply chains, Financial Times: Opinion Trade Secrets

Bpifrance (2018), La Région Nouvelle-Aquitaine, L'Etat, Business France, Bpifrance et la CCI Régionale créent la «Team France Export Nouvelle-Aquitaine » au service des entreprises qui veulent réussir à l'international, https://presse.bpifrance.fr/la-region-nouvelle-aquitaine-letat-business-france-bpifranceet-la-cci-regionale-creent-la-team-france-export-nouvelle-aquitaine-au-service-des-entreprises-quiveulent-reussir-a-lin/ 
Brezzi, M. and P. Luongo (2016), "Regional Disparities In Access To Health Care: A Multilevel Analysis In Selected OECD Countries", OECD Regional Development Working Papers, No. 2016/04, OECD Publishing, Paris, https://doi.org/10.1787/5jm0tn1s035c-en.

Buissou Julien, «Pascal Lamy : «Le COVID-19 va accélérer le passage du protectionnisme au précautionnisme », Le Monde, 9 avril 2020, https://www.lemonde.fr/economie/article/2020/04/09/pascal-lamy-le-COVID-19-va-accelerer-lepassage-du-protectionnisme-au-precautionnisme 6036080 3234.html

Business France (2020), "Baromètre de l'activité internationale des entreprises françaises -période Covid-19 » (10 avril 2020), https://www.businessfrance.fr/barometre-de-l-activite-internationale-desentreprises-francaises-periode-COVID-19

Campus France (2018), Observatoire territorial de la mobilité internationale des étudiants et des chercheurs, https://www.campusfrance.org/fr/ressource/observatoire-territorial-de-la-mobiliteinternationale-des-etudiants-et-des-chercheurs

$\mathrm{CCl}$ (2019), "Team France Export : le nouveau dispositif en ordre de marche », Chambre de commerce et d'industrie, 7 février 2019, https://www.cci.fr/web/presse/communiques-fiches/lasset publisher/ul50/content/cp-team-france-export

CGET (2017), “ Circulaire sur les Commissions régionales de stratégie numérique » (22 février 2017), https://www.cget.gouv.fr/circulaire-commissions-regionales-de-strategie-numerique

CGET (2015), Synthèse des stratégies régionales de l'innovation en vue de la spécialisation intelligente des régions françaises, https://www.cget.gouv.fr/ressources/publications/synthese-des-strategiesregionales-de-l-innovation-en-vue-de-la-specialisation-intelligente-des-regions-francaises

Charbit, C. et M. Tharaux (2020), « Migrants: A critical aspect of COVID policy responses and recovery ", The OECD Forum Network (28 May 2020), https://www.oecd-forum.org/posts/migrants-acritical-aspect-of-covid-policy-responses-and-recovery

Charbit, Cl. (2020) "From « de jure » to « de facto » decentralised public policies: the Multi-Level Governance approach" in the Special symposium on Multi-Level Governance, The British Journal of Politics and International Relations, Vol 22, Issue 4:753-936

Charbit, C. (2011), "Governance of Public Policies in Decentralised Contexts: The Multi-level Approach", OECD Regional Development Working Papers, 2011/04, OECD Publishing http://dx.doi.org/10.1787/5kg883pkxkhc-en

Charbit, C. and M. Michalun (2009), "Mind the Gaps: Managing Mutual Dependence in Relations among Levels of Government", OECD Working Papers on Public Governance, No. 14, OECD Publishing, Paris, https://doi.org/10.1787/221253707200

Charron, N., Djikstra, L. and Lapuente V. (2014), "Regional Governance Matters: Quality of Government within European Union Member States" Regional Studies, Vol. 48; https://doi.org/10.1080/00343404.2013.770141

Cheriet, Foued (2010), Modèle d'Uppsala et implantation des firmes multinationales agroalimentaires, Revue française de gestion, no. 201, pp. 45-64

CIEDEL (2017), L'irrésistible internationalisation des villes et des territoires : Enjeux, Dynamiques, Perspectives, Centre International d'Etudes pour le Développement Local, Actes du Colloque, 11-12 décembre 2017, Lyon, https://www.ciedel.org/wp-content/uploads/2018/05/synth\%C3\%A8secolloque-internationalisation-des-villes-et-des-territoires.pdf

Colrat, A., A. Decludt, J. Cartier, F. Gomez, P. Gudefin, G. Caude, B. Fulda, F. Marendet (2018), La transformation du modèle économique des grands ports maritimes, Rapport de l'Inspection générale des finances et du Conseil général de l'environnement et du développement durable (novembre 2018). 
European Commission (2020), Communication de la commission - Orientations à l'intention des États membres concernant les investissements directs étrangers et la libre circulation des capitaux provenant de pays tiers ainsi que la protection des actifs stratégiques européens, dans la perspective de l'application du règlement (UE) 2019/452 (règlement sur le filtrage des IDE), https://eurlex.europa.eu/legal-content/FR/TXT/HTML/?uri=OJ:C:2020:0991:FULL\&from=EN

European Commission (2020b), «Recovery plan for Europe », https://ec.europa.eu/info/live-work-traveleu/health/coronavirus-response/recovery-plan-europe en

Conseil national de l'industrie (2020), « La filière infrastructures numériques », https://www.conseilnational-industrie.gouv.fr/la-filiere-infrastructures-numeriques

Cour des comptes (2020), L'entrée, le séjour et le premier accueil des personnes étrangères, Rapport public thématique, https://www.vie-publique.fr/sites/default/files/rapport/pdf/274248.pdf

De Mello, L. et T. Ter-Minassian (2020), « The COVID-19 crisis creates an opportunity to step up digitalisation among subnational governments" (20 April 2020), https://oecdecoscope.blog/2020/04/20/the-covid-19-crisis-creates-an-opportunity-to-step-updigitalisation-among-subnational-governments/

French Republic (2020a), “Code général des collectivités territoriales », Legifrance, https://www.legifrance.gouv.fr/affichCode.do?cidTexte=LEGITEXT000006070633

French Republic (2020b), «Éclairage : les compétences des régions : aperçu après la loi NOTRe », Vie publique, https://www.vie-publique.fr/eclairage/38411-les-competences-des-regions-apercu-apres-laloi-notre

French Republic (2020c), Décret $n^{\circ} 2020-964$ du 31 juillet 2020 relatif aux attributions du ministre délégué auprès du ministre de l'Europe et des affaires étrangères, chargé du commerce extérieur et de l'attractivité, Legifrance, https://www.legifrance.gouv.fr/jorf/id/JORFTEXT000042185565/

French Republic (2018), Discours du Premier ministre sur la "Stratégie du Gouvernement en matière de commerce extérieur 》 (Roubaix, 23 février 2018), https://www.gouvernement.fr/sites/default/files/document/document/2018/02/discours de m. edouar d philippe premier ministre presentation de la strategie du gouvernement en matiere de commerce exterieur a roubaix 23.02.2018.pdf

French Republic (2017), «Revitalisation et réindustrialisation - Bilan du commissariat spécial des Hautsde-France », Préfecture de Région des Hauts-de-France (6 décembre 2017), https://www.prefectures-regions.gouv.fr/hauts-de-france/Actualites/Revitalisation-etreindustrialisation-Bilan-du-commissariat-special-des-Hauts-de-France

French Senate (2019), Projet de loi de finances pour 2019 : Action extérieure de l'État : Diplomatie culturelle et d'influence, Rapport législatif, http://www.senat.fr/rap/a18-149-2/a18-149-23.html

French Senate (2020), Projet de loi de finances pour 2017 : Économie, https://www.senat.fr/rap/l16-140311//16-140-3118.html

Gerschel, E., Martinez, A., \& Mejean, I. (2020). Propagation des chocs dans les chaînes de valeur internationales: le cas du coronavirus. Notes IPP.

Hendrickson C. and Muro M. (2020), Will COVID-19 rebalance America's uneven economic geography? Don't bet on it, Brookings Institute, The Avenue

Hirst, P. et G. Thompson (2002), "The Future of Globalization”, Cooperation and conflict, No. 37 (3), pp. 247-265, https://doi.org/10.1177/0010836702037003671

Hombert, A. and A. Matray (2015), "US manufacturing firms, R\&D and resilience to import competition from China", VOX CEPR Policy Portal, https://voxeu.org/article/innovative-firms-and-resiliencechinese-import-competition.

ICC International (n.d.), Team France Export des Hauts -De-France, https://cci-international.net/fr/team- 
france-export/

Knight, F. (1921), Risk, Uncertainty and Profit.

Lembcke, A. and L. Wildnerova (2020), "Does FDI benefit incumbent SMEs?: FDI spillovers and competition effects at the local level", OECD Regional Development Working Papers, No. 2020/02, OECD Publishing, Paris, https://doi.org/10.1787/47763241-en.

Lileeva, A. and D. Trefler (2020), "Improved access to foreign markets raises plant-level productivity... For some plants", The Quarterly Journal of Economics, Volume 125, Issue 3, August 2010, Pages 1051-1099, https://doi.org/10.1162/qjec.2010.125.3.1051.

McCann, Ph. (2020) "Perceptions of regional inequality and the geography of discontent: insights from the UK", Regional Studies, 54:2, 256-267, DOI: 10.1080/00343404.2019.1619928

Ministère de l'agriculture et de l'alimentation (2020), « COVID-19 : poursuite de la chaîne logistique du transport de marchandises » (18 mars 2020), https://agriculture.gouv.fr/covid-19-poursuite-de-lachaine-logistique-du-transport-de-marchandises

Ministry of Economy, Finance and Recovery, and CCI France (2019), Contrat d'objectifs et de performance, 15 avril 2019.

Ministry in charge of Environment, Energy, Sea, and International Relations on Climate (2017), Atlas des entrepôts et des aires logistiques en France en 2015, Datalab (mars 2017).

Ministry of Europe and European Affairs (2020), https://www.gouvernement.fr/ministere-de-l-europe-etdes-affaires-etrangere

Ministry for Territorial Cohesion and Relations with Local Government (n.d.), Les principaux établissements publics, https://www.cohesion-territoires.gouv.fr/agences-et-etablissements-publicsdu-ministere

Ministry of Economy, Finance and the Recovery (n.d.), La Team France Export est le dispositif public d'accompagnement des entreprises à l'international structuré autour de Business France, des régions, des Chambres de Commerce et d'Industrie et de Bpifrance.

https://www.tresor.economie.gouv.fr/services-aux-entreprises/team-france-export

Mouhoud, El Mouhoub (2020), "Délocalisations : comment faire machine arrière ?" Alternatives économiques (Mai 2020)

Occitanie Region (2020), «Soutien à l'accueil et à l'intégration des demandeurs d'asile et des bénéficiaires d'une protection internationale ", https://www.laregion.fr/Soutien-a-l-accueil-et-a-lintegration-des-demandeurs-d-asile-et

OECD (2021), Fostering economic resilience in a world of open and integrated markets: risks, vulnerabilities and areas for policy action, https://www.oecd.org/newsroom/OECD-G7-ReportFostering-Economic-Resilience-in-a-World-of-Open-and-Integrated-Markets.pdf

OECD (2020a), Perspectives économiques de l'OCDE: L'économie mondiale sur une ligne de crête, (Juin 2020), https://doi.org/10.1787/0d1d1e2e-en

OECD (2020b), L'impact territorial du Covid-19 : Gérer la crise entre niveaux de gouvernement, (Mise à jour, avril 2020) http://www.oecd.org/coronavirus/policy-responses/limpact-territorial-du-covid-19gerer-la-crise-entre-niveaux-de-gouvernement-2596466b/

OECD (2020c), Coronavirus (COVID-19) From pandemic to recovery: Local employment and economic development, (Updated 27 April 2020), http://www.oecd.org/coronavirus/policy-responses/frompandemic-to-recovery-local-employment-and-economic-development-879d2913/

OECD (2020d), Pilot Database on Regional Government Finance and Investment: Key findings, OECD Publishing, Paris, http://www.oecd.org/cfe/regionaldevelopment/REGOFI Report.pdf

OECD (2020e), Capacity for remote working can affect lockdown costs differently across places, http://www.oecd.org/coronavirus/en/policy-responses 
OECD (2020f), COVID-19 and global value chains: Policy options to build more resilient production networks, , http://www.oecd.org/coronavirus/en/policy-responses

OECD (2019a), Déclaration sur les politiques permettant de forger un avenir meilleur pour les régions, les villes et les zones rurales, Athènes, $4^{\mathrm{e}}$ Réunion ministérielle du Comité des politiques de développement régional (RDPC) de l'OCDE, https://www.oecd.org/regional/ministerial/RDPCMinisterial-Declaration-FR.pdf

OECD (2016), « Examen par l'OCDE des initiatives statistiques visant à mesurer le tourisme à l'échelon infranational », Études de l'OCDE sur le tourisme, 2016/01, Éditions OCDE, Paris. http://dx.doi.org/10.1787/cf0cfa00-fr

OECD (2019), «France », dans OECD Regional Outlook 2019 : Leveraging Megatrends for Cities and Rural Areas, Éditions OCDE, Paris, https://doi.org/10.1787/9e936eee-fr

OECD (2019b), Panorama des administrations publiques 2019, OECD Publishing, Paris, https://doi.org/10.1787/8be847c0-fr.

OECD (2019c), Réussir la décentralisation: Manuel à l'intention des décideurs, OECD Publishing, Paris, https://doi.org/10.1787/551847c0-fr.

OECD (2019d), "Decentralised development co-operation: Unlocking the potential of cities and regions", OECD Development Policy Papers, No. 22, OECD Publishing, Paris, https://doi.org/10.1787/e9703003-en.

OECD (2019e), "Tendances actuelles de la décentralisation", in Réussir la décentralisation: Manuel à l'intention des décideurs, OECD Publishing, Paris, https://doi.org/10.1787/7d478b76-fr.

OECD (2019f), "Innovative multi-level governance to address future challenges", in OECD Regional Outlook 2019: Leveraging Megatrends for Cities and Rural Areas, OECD Publishing, Paris, https://doi.org/10.1787/34e0eb81-en.

OECD (2018b), Regions and Cities at a Glance 2018, page 69, OECD Publishing, Paris, https://doi.org/10.1787/reg cit glance-2018-en

OECD (2018), Job Creation and Local Economic Development 2018: Preparing for the Future of Work, OECD Publishing, Paris, https://doi.org/10.1787/9789264305342-en.

OECD (2018), Productivity and Jobs in a Globalised World: (How) Can All Regions Benefit?, OECD Publishing, Paris. http://dx.doi.org/10.1787/9789264293137-en.

OECD (2018), Reshaping Decentralised Development Co-operation: The Key Role of Cities and Regions for the 2030 Agenda, OECD Publishing, Paris, https://doi.org/10.1787/9789264302914-en

OCDE, Recommandation du Conseil sur l'investissement public efficace entre niveaux de gouvernement, OECD/LEGAL/0402

OECD (2015), Policy Framework for Investment, 2015 Edition, OECD Publishing, Paris, https://doi.org/10.1787/9789264208667-en.

OECD (2010), Measuring Globalisation: OECD Economic Globalisation Indicators 2010, OECD Publishing, Paris, https://doi.org/10.1787/9789264084360-en.

Poulhès, M. (2015). Are Enterprise Zones benefits capitalized into commercial property values? The French case.

Régions de France (2020), « Donner aux territoires les moyens de reconquérir notre souveraineté alimentaire » (8 juin 2020), http://regions-france.org/actualites/actualites-nationales/donner-auxterritoires-moyens-de-reconquerir-souverainete-alimentaire/

Régions de France (2020a), "Plan de relance de l'économie : les Régions proposent un New Deal industriel et environnemental », 6 avril 2020, http://regions-france.org/actualites/actualitesnationales/regions-remercient-gouvernement-plan-relance/

Régions de France (2020b), « La Région, quelles compétences ? », http://regions- 
france.org/observatoire-politiques-regionales/la-region-quelle-comptetence/

Régions de France (2019), « Risque de fin du plan France Très Haut Débit: les députés sont le dernier recours ! » (13 décembre 2019), http://regions-france.org/actualites/actualites-nationales/fibreoptique-menace-plan-france-tres-haut-debit/

Régions de France (2018), Le rôle économique des régions : De l'ambition à l'action.

Rodríguez-Pose, Andrés (2017), "The revenge of the places that don't matter (and what to do about it)", Cambridge Journal of Regions, Economy and Society, No. 11 (1), pp. 189-209, https://doi.org/10.1093/cjres/rsx024

Saudemont, E. (2020), “ [Covid-19] Les régions françaises se mobilisent pour soutenir les entreprises en difficultés » (13 mars 2020), L'Usine nouvelle, https://www.usinenouvelle.com/editorial/les-regionsaffirment-leur-soutien-aux-entreprises.N939891

Scholte, J. (2008), « Defining globalisation », The World Economy, Vol. 31, pp 1471-1502, https://doi.org/10.1111/j.1467-9701.2007.01019.x

Sodupe, K. (1999), 'The European Union and Inter-regional Cooperation.' In F. Aldecoa and M. Keating (eds.), Paradiplomacy in Action: The Foreign Relations of Subnational Governments, Psychology Press, London.

Subramanian A. (2020), "After Capital A Radical Agenda to Tame Inequality, Foreign Affairs:

Review Essays", Foreign Affairs (July/August 2020),

Team France Export (2019), Comité directeur, 26 septembre 2019.

Team France Export (2020), "[COVID-19] Webinaires marchés et solutions face à la crise » (1 ${ }^{\text {er }}$ juin 2020), https://www.teamfrance-export.fr/hautsdefrance/actualites/vos-marches-face-a-la-crise--nosreponses-en-direct

Team France Export (n.d.), 30 Partenaire et Réseaux Porteurs de « Solutions Team France Export » https://www.teamfrance-export.fr/documents/partenaires.pdf

Team France Export National (n.d.), « Vous faire gagner à l' international », https://team-france-exportnational.cdn.prismic.io/team-france-export-national\%2Fcbe11435-e59e-4a13-9ff1$\underline{526 \mathrm{c} 63029388 \text { tfe leaflet } 105 \times 250 \text { web.pdf }}$

Tuccio, M. (2019) Measuring and Assessing Talent Attractiveness in OECD Countries, OECD Publishing, Paris, https://doi.org/10.1787/b4e677ca-en

World Economic Forum (2016), The Global Competitiveness Report 2016-2017. Insight Report. World Economic Forum. Geneva, Switzerland. 